\title{
Kernos
}

Revue internationale et pluridisciplinaire de religion grecque antique

9| 1996

Varia

\section{Epigraphic Bulletin for Greek Religion}

\section{Angelos Chaniotis}

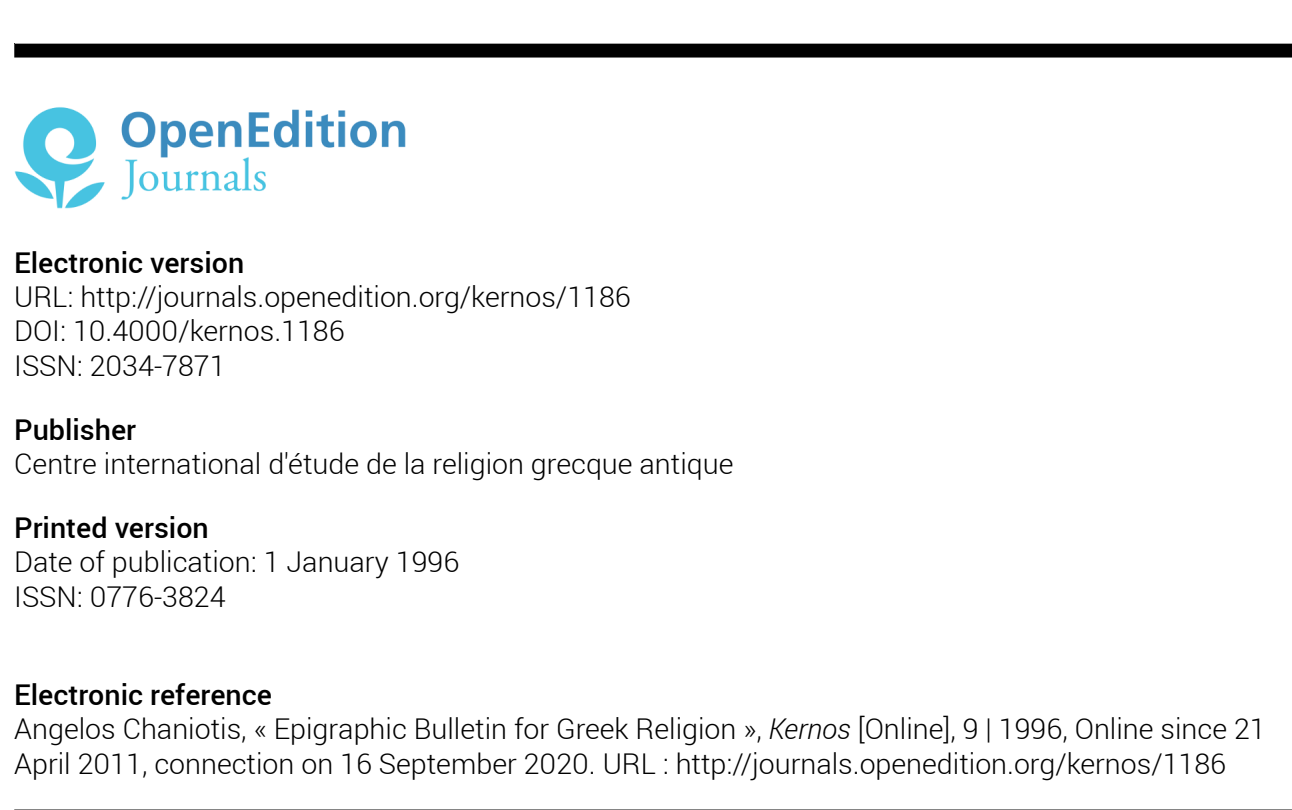

Kernos 


\section{Epigraphic Bulletin for Greek Religion 1992 (EBGR)}

The sixth issue of $E B G R$ presents a large part of the publications of 1992 and several addenda to EBGR 1990-1991. The principles explained in Kemos, 4 (1991), p. 287-288 and Kernos, 7 (1994), p. 287 apply also to this issue. As usually, works devoted exclusively to aspects of Greek religion (marked here with an asterisk) are presented very briefly. I would like to express my gratitude to all the scholars who have encouraged me to continue this bulletin. The abbreviations used are those of L'Année Pbilologique and the Supplementum Epigrapbicum Graecum. I am aware that many publications escape my notice and even more are not accessible on time. The sending of offprints, especially of less accessible publications, would certainly help my work. I am very much obliged to Eftychia Stavrianopoulou [ES] for supplying several lemmata and to Laura Hebert for improving the English text.

\section{Additional abbreviations}

AEMT, 3:

Africa Romana, 9:

Boeotia Antiqua, 2:

Delphes:

Economics of Cult:

Eumousia:

Goddess and Polis:

Initiation:

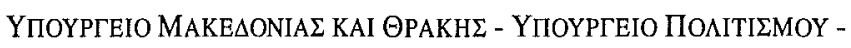

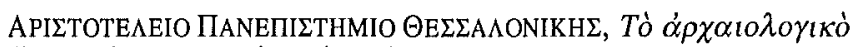

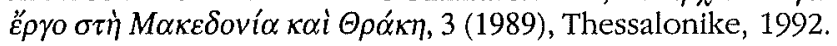

A. MASTiNo (ed.), L'Africa romana. Atti del IX convegno di studio 1991, Sassari, 1992.

J.M. Fossey (ed.), Boeotia Antiqua II, Amsterdam, 1992.

J.-F. Bommelaer (ed.), Delphes. Centenaire de la "Grande Fouille" réalisée par l'École Française d'Athènes (18921903). Actes du Colloque Paul Perdrizet, Strasbourg, 6-9 novembre 1991, Leiden-New York-København-Köln, 1992.

T. LINDERS - B. ALROTH (eds), Economics of Cult in the Ancient World. Proceedings of the Uppsala Symposium 1990, Uppsala, 1992.

J.-P. Descoeudres (ed.), Eumousia. Ceramic and Iconograpbic Studies in Honour of Alexander Cambitoglou, Sydney, 1990.

J. NEILS (ed.), Goddess and Polis: The Panathenaic Festival in Ancient Athens, Princeton, 1992.

A. Moreau (ed.), L'initiation. Actes du colloque international de Montpellier 11-14 auril 1991, Montpellier, 1992. 
Kotinos:

Marseille grecque:

Mélanges Lévêque, 6:

Pbilolakon:

Polydipsion Argos:

Samotbrace, 7:

Le sanctuaire grec:

Theocharis:
H. Froning - T. HÖLSCHER - H. MIELSCH (eds), Kotinos. Festschrift für Erika Simon, Mainz, 1992.

M. BuTS - G. BERTUCCHI - G. LONGES - H. TREZING (eds), Marseille grecque et la Gaule. Actes du colloque international d'bistoire et d'archéologie et du Ve congrès archéologique de la Gaule méridionale. Marseille, 18-23 novembre 1990, Aix-en-Provence, 1992.

M.M. MactouX - E. GenY (eds), Mélanges Pierre Lévêque. VI. Religion, Paris, 1992.

J.M. SANDERS (ed.), $\Phi_{l} \lambda \circ \lambda \alpha \alpha_{k} \kappa v$. Lakonian Studies in Honour of Hector Catling, London, 1992.

M. PIÉrart (ed.), Polydipsion Argos. Argos de la fin des palais mycéniens à la constitution de l'État classique, Fribourg (Suisse), 7-9 mai 1987 (BCH, Suppl. 22), Paris, 1992.

J. MCCRedie - G. Roux, Samothrace, 7. The Rotunda of Arsinoe, Princeton, 1992.

A. SCHACH'tER (ed.), Le sanctuaire grec. Huit exposés suivis de discussions, Vandceuvres-Genève, 20-25 août 1990, Genève, 1992 (Entretiens Hardt, 37).

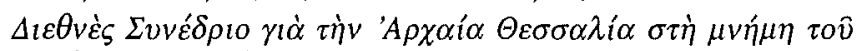
$\Delta \eta \mu \dot{\tau} \tau \rho \eta P$. . $\Theta \varepsilon o \chi \alpha ́ \rho \eta$, Athens, 1992.

\section{Selected Topics}

Geographical areas (in the sequence adopted by $S E G$ )

Attica: 1. 6. 8. 22, 35. 37. 41. 56. 79. 87. 88. 90. 99. 122. 123. 130. 134, 140. 157. 168, 169, 170, 188, 201, 204. 213, 226. 234. Peloponnesos: Korintbia 7. 28, 207. 212; Argolis 24. 32. 46. 119. 120. 149. 164. 175. 176. 188; Epidauros 79. 125. 127. 217. 239. 240. 241; Lakonia 37. 171, 188. 211. 243; Messenia 168, 188. 221. 222. 243; Arkadia 6. 35. 106. 121. 147. 182. 243; Olympia 97. 231. Megaris: 72. Boiotia: 58. 72. 77. 115. Delphi: 2. 11. 29. 30, 31. 35. 97. 106. 108, 150, 152, 153. 181. 196. 201. Aitolia: 190. Doris: 219. Thessaly: 48. 79. 116. 232. Epeiros: 30. 97. 228. Macedon: 5. 6. 47. 92. 117. 124. 128, 233. 236. 237. Thrace: 83. 200. 225. 234. North Shore of the Black Sea: 44. 245. Delos: 35. 97. 106. 129. 130. 131. 224. 234. Rhodes: 165. 243. Lesbos: 4. 165. Kos: 17, 56, 79, 165. 166. Cyclades: 6. 18, 102, 106. 141, 143. 163. 194. Chios: 29. 198. Samos: 78. 79. 210. Thasos: 17.64 .194 . Samothrake: 91.128 .150 .162 .191$. Euboia: 79.176 . Crete: $6.21,43.67,79.106,112.173$. Sicily: 3. 17. 36. 61. 67. 81. 121, 122. 135. 137. 138. 158. 159. Italy: 3. 17. 39. 52. 53. 57. 60. 121. 154. 180, 192. 193. 199. 223. Britannia: 75. Gaul: 54. 82. 121. 195. Spain: 139. Asia Minor: 34. 40. 84. 96. 118. 177, 185. 234. 242. 244; Karia 25. 26. 27. 38. 56. 71. 110. 148, 180. 209. 230; Ionia 54. 59. 67. 84. 86. 87. 101. 110. 145. 150. 187. 189. 197; Lydia 42. 84. 173. 185; Troas 203; Mysia 95. 151. 174; Bitbynia 55. 183; Pontos 73. 74. 166. 184; Galatia 62. 185. 218; Phrygia 51. 132. 133. 179. 185. 244; Pisidia 34. 100. 103. 104. 160. 161. 243; Pamphylia 34. 67; Lykia 105; Lykaonia 64. 126; Kilikia 220. Cyprus: 74. Mesopotamia: 178. Syria: 89, 109. Palaestina: 70. 227. Arabia: 142. Egypt: 12. 13. 14. 15. 16. 23. 88. 113. 202. 205. 208. Kyrene: 6. 35. 42, 66. 67. 166. 243. 
abaton: 94

abortion: 50

acclamations: 181; see also Greek words

agons, agonistic inscriptions: 13 (Basileia). 24 (Nemea). 25 (Artemidoreia, Karneia). 29. 30 (Isthmia, Nemea, Pythia). 56 (Panathenaia, Koresia, Asklepieia). 92. 103 (Sebasta Solymeia). 104. 115 (Basileia, Charitesia). 119 (Heraia), 149 (Heraia). 157 (Panathenaia), 160 (agon politikos, Kaisareios Kesbelios, themis Panathenaike, Artemisios, Olympia). 176 (Isthmia, Nemea). 181. 188, 204 (Panathenaia). 233. 242 (Karia). 244 (Augusteia Asias, Deia, Olympia, Panhellenia, Rhomaia Sebasta, Traianeia); commemorative agons: 104. 160; see also festivals

alphabetical oracles: 176

altar: 13. 14. 25. 41.92.94. 125. 126. 138. 146. 166. 186. 217. 218. 219

amphictiony: 31

amulets: 20. 68. 208. 238; see also gems, magic

angels: $156,185.186$

animals in religion and magic: 80 ; birds 69 ; dolphin 163 ; eagle 163 ; fish 47 ; borse 231 ; pigeon 42; lion 65. 67. 126. 163. 217; snake 13. 16. 208. 214. 215. 216; probibitions against $a$. in sanctuaries 12

apotropaic objects, symbols, words: 20.67 .80 .112 .121 .156 .178 ; see also amulets, baetyls, gems

archegetes: 103, 169

aretalogy: 234

arkteia: 6

associations: $10,12,13,46,55,77,82,124,126,137,168,169,170,185,186 ?, 237,245$; of atheletes 25. 39; of Dionysiac technitai 11, 12

astragal-oracles: 160

asylia: 12.19 .26 ; see also supplication

baetyls: 67.121

banquet: 17.55 .154 .201

birth: 6.50 ; bithdays: 12.99

burial: see funerary cult

calendar: 74. 91, 143, 183, 194, 195. 230

caves: 41,43

clothing regulations: 36.50

colony and mother city, religious relationships: 137.194 .195 .228 .243

columbaria: 42

confession inscriptions: $136,172.181 .185 .234$

continuity of cult: $\mathbf{4 3}$

crowns: see wreaths

crys: 77

cult: chthonic 212; continuity 43; family c. 17. 50, 79. 82; introduction of c. 79. 234; of mortals $12.18,19,25.176$; private $c .163$; see also emperor cult, heroic cult, royal cult, rituals

cult objets / paraphernalia: 154. 212; see also Greek words

curses: see defixiones, imprecations

dance: 84.229

days, named after gods: 12.74

death: 12. 13. 50. 55; see also metempsychosis, underworld 
dedications: 1. 19. 25. 35. 43. 62. 81. 90.92. 97. 98. 113. 121, 130. 131. 147. 199. 211. 213. 226. 229. 235

defixiones: $20.25 .44,76.134$

deities: Agathe Tyche: 25. Agathos Daimon: $c f$. 12. 26. Amphitrite: 244. Anak(t)es: 25. 196. Aphrodite: 12. 13 (Thea Neotera), 17. 25. 42. 53. 54. 69. 74. 121. 138. 165. 169. 208. 220. 228. 230. 238; Akraia 230; Doritis 180; Epekoos 101; Epiteuxidia 237; Euploia 180; Knidia 25. 180; Ourania 61. Apollon: 6. 11. 12. 13. 17. 25. 41. 42. 67. 83. 99. 112. 126. 129. 135. 137. 138. 139. 161. 163. 165. 171. 178. 182. 185. 186. 208. 225. 228. 239; Agyieus 222. 228; Aularkenos 83; Axyros 136; Delphinios 54. 195; Karneios 25. 137. 171; Klarios 67. 84. 179. 187; Komaios 178; Lyk(e)ios 25. 121; Maleatas 79. 125; Milasios 25; Pbospboros 179; Pythaeus 119; Pytbios 25. 64. 92. 181. 228; Soter 228; Thargelios 195; Thermios 190. Ares: 8. 53. 160. Artemis: 6. 8. 34. 43. 48. 84 . 92. 103. 126. 138, 160. 165. 220. 221. 236; Agrotera 154. 228; Aristoboule 79; Brauronia 6. 90; Epekoos 100; Epbesia 54. 84. 100. 177. 195; Ephodia (?) 24; Hegemone 92. 228; Hekate 64; Hemera 147. 182; Hiakyntbotrophos 25; Koloene 84; Kyparissia 221; Medeia 177; Ortheia 221; Pasikrate 228; Pergaia 163. 228; Phosphoros 84; Soteira 13. 72. 84. 142. Asklepios: 1. 25. 60. 79. 85. 92. 127. 151, 160, 161, 166. 185. 228, 239. 240. 241. Athena: 8. 13. 25. 32. 79. 126. 160. 207?; Chalinitis 228; Hippia 213; Lindia 12. 244; Nike: 79; Nikephoros 25; Pallas 239. 241; Polias 165. 244; Soteira 169. Charites: 64. Demeter: 25. 42. 66. 79. 92. 122. 128. 132. 150. 161. 199, 207. 215. 220; Chamyne 231; Konia 231; Thesmophoros 122. Dikaiosyne: 185. Dike: 185. Dione: 228. Dionysos: 6. 12. 13. 25. 87. 92. 99, 118. 126. 141. 150. 169. 185. 195. 215. 234. 236. 245; Bakchos 25; see also Satyrs, Silens. Dioskouroi: 25. 92. 105. 111. 159. 160. 165. 191. 196; see also Anak(t)es, Samothrake. Eileithyia: $25.43,137$. Eileithyiai: 25 . Enodia: 48. Eros: 25. 121. Eukleia: 5. Ge: 25. 126. Hekate: 48. 110. 132. 150. 214. 220; Ephodia (?) 24; Propylaia 67; Soteira 132. 133. 165; see also Artemis. Helios: 15 (Zeus Helios). 25.132. 160. 161. 174. 185. 186. Hephaistos: 46. Hera: 13. 17. 25. 54. 56. 78. 119. 125. 161. 175. 208. 210. Herakles: 13. 25. 38. 39. 50. 54. 64. 67. 81, 105. 112.119. 160. 161. 168. 178. 185. 186. 208. 214. 222; Charops 58; Leuktriades 115; Pankrates 22. Hermes: 8. 13. 21. 25. 34. 92. 110. 126. 168. 185. 214. 222; Agoraios 200. Hestia: 13, 25. 228; Boulaia 25. Homonoia: 26. Hosia kai Dikaia: 185. Hosios kai Dikaios: 174. 185. 186. Hyakinthos: cf. 25. Hygieia: 239. Iatros: 112. 166. Kabeiroi: 77. Kore: 13. 25. 66; cf. Persephone. Leto: 13. 54. 165. Leukothea: 195. Malophoros: 17. Men / Mes: 65. 123. 132. 185. Meter Theon: 74. 185. 239. Muses: 18. 25. 75. Nemesis: 79. 140. 161. 169. Nike: 112. 160 (Nike Themis). Nymphs: 25.137. 228. Pan: 41. 53. 79. 227. 239. 240. 241. Panakeia: 166. Pantes Theoi: 25. 239. Pantheos: 126. Pater Theon: 241. Peitho: 25. Persephone: 47. 53. 128. 135; cf. Kore. Plouton: 25. Ploutos: 126. Poseidon: 48. 142. 163. 236. 244; Asphaleios 142; Hippios 54. 116; Impsios 116; Phykios 50. Roma: 92. 161. Selene: 132. 185, 220. Themis: 140. 160 (Nike Themis). Theoi Agoraioi: 92. Tyche: 185; Poleos 160. 161. Zeus: 13. 24. 25. 42. 65. 92.103. 112. 132. 160. 161. 163. 208. 218. 228. 244; Amalios 50; Ammon 236; Apoptropaios: 50; Atabyrios 137; Bronton 185; Dorites 70 ; Eleutherios 13; Ensitarchios 24; Epekoos 105; Exakester 137; Helios: 15; Hypatos 50; Hypsistos 92. 185; Idaios 43; Kesbelios 160; Ktesios 25; Kronion 241; Olbios 185; Olympios 52. 53. 98. 105; Osogo 25; Otorkondeon 25; Meilicbios 25. 48; 
Patroos 82. 166?. 242?; Polieus 165; Prytanis 228; Solymeus 103. 104; Soter 25. 137. 142. 169. 205; Soterios 13; Thaulios 48; Thenatas 43; see also festivals deities, chthonic 66. 212. 231; Anatolian 34. 104 (Kakasbos). 220 (Perasia); Egyptian 12.

13. 14. 15. 25. 45. 66. 79.92. 94. 111. 113. 115. 118. 138. 208. 211. 234; female

47; motber d. 47. 54. 220; Oriental 13 (Agdistis). 47 (Atargatis, Dea Syria). 49 (Mithras). 100 (Kybele). 111 (Mithras). 177 (Anahita). 195 (Kybele); Thracian 16 (Heron). 79 (Bendis). 111 (Heron)

deities, arrival of 25; comparison of mortals with gods 12.95 ; lists of 8 ; protectors of birth, fertility 43. 84; protectors of agriculture 66. 105. 185; protectors of bousebold 83.185 .186 ; protectors of magistracies 25 ; protectors in wars 70; riders 111.117 .185 ; rulers of cities/villages 79.234 ; see also agons, cults, festivals, healing

disease: see healing

divination: 33. 41.185 (prophetes). 187 (chresmologos). 211; see also oracles

dreams: 25; dream interpreters: 75

Eleusis, Eleusinian goddesses: 19. 35. 79. 100. 231. 244

emperor cult: 13. 25. 26. 40, 45, 62, 74, 92, 96. 99. 103. 105. 126, 146, 160. 161, 184, 219.

244; identification of emperors with gods: 13 (Augustus-Zeus Eleutherios). 99 and 126 (Augustus-Apollon)

epigrams: 9. 13. 25. 30. 38. 55. 120.128. 146. 173.174. 193. 205

epiphany: 79. 111. 172. 234; see also Greek words, émı $\varphi$ av́s

exclusion from cult: 50

family: see cults: $17.50,79.82$

festivals: 19. 21. 59. 92. 97. 99. 115. 201. 213; Apatouria 201; Apellai 201; Artemidoreia 25; Bouphonia 201; Dionysia 6. 12. 25. 87. 187. 201. 213; Gymnopaidiai 171. 188; Hekatombaia 188; Herakleia 79; Hiakyntbotrophia 25; Hyakintbia 37. 171; Ithomaia 188; Kallynteria 79; Karneia 25. 171; Klaria 187; Leukopbryena 19. 25; Nekysia 12; Nikephoria 19; Olympieia 188; Oschopboria 188; Panathenaia 37. 56. 88. 123. 157. 188, 201. 204; Parparonia 188; Plynteria 79; Ptolemaia 88; Soteria 19; Synoikia 188; Theadelpheia 23; Theseia 201; Thesmopboria 122. 143. 201; new year f. 188; festivals related to agriculture

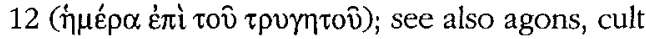

fire: 84 ; fire-walking: 220

foreigners, exclusion / participation: 50, 201

founders of cities: see archegetes, ktistes, oikistes

funerary cult / practices: 9, 12. 14. 25. 26. 55. 65. 73. 95. 101, 103. 104, 126. 128. 132. 133. 146. 161. 177. 193. 218. 237; see also death, imprecations, underworld gems: 20.80 .89 .156 .208 .214 .215 .216 .238 ; see also amulets, magic

gestures: 13, 174

ghosts: 67

Gnostic gems: see gems

graves: see funerary cult / practices

groves: 12.85 .146

healing, healing deities, health: 13. 20. 25. 59. 67. 79. 85. 112. 127. 139. 145. 156. 166. 172. 217.242

herald: 154

heroes, heroic cults: 114. 164. 198; Alektryon 119; Aristea 54; Epimachos 25; Heros Archegetes 169; Heros Auloneites 117; Homer 143; Hyakintbos 171; Iphigeneia 6; Kerkaphos 165; Merops 25; 'the Seven' 164; Sphettos 198; Theseus 79. 188; Thracian bero 83; Toxaris 79; heroic descent: 38, 120; 
heroization: 25 (of an athlete), 203 (of a benefactor); heroization of the dead: 25. 92; see also mythology

hymns: 11. 12. 234. 239. 241

impiety: 25. 79. 234; impious jokes: 103

imprecations: 12.35 .86 . 197; funerary i.: 25.51 .55 .65 .73 .109 .126 .174 .218 ; see also defixiones

incantation: 67.69 .112

incubation: $85,127,229$

initiation: 6. 21. 37. 66.91, 201

introduction of new cults: $79,100,163$

inventories: see sanctuaries

invocations: 13.20 .177

Judaism: 12. 111, 148. 185. 209

justice, divine: 185 ; see punishment

keys: 110.140

ktistes: $25.71,161$

leges sacrae: $12.19 .22 .25 .35 .36 .50 .67 .79,110.165 .201 .229$

Lethe: 13

loom weights: 43,122

magic: $20.33 .67 .68,76,77,80.84,89.110,111,156,208,214.215 .216,238$

manumissions: 47. 153. 199

metempsychosis: 245

Minoan religion: 43

miracles: $60.127,181,217$; see also healing

months: see calendar

mystery cults, mysts: 43. 49. 55. 77. 91. 100.126. 128. 160. 179. 192

myths: 54; m. figures: 8 (Sarpedon). 20 (Atalanta, Laodameia, Telephos). 25 (Inopos, Merops). 29 (Meleagros). 108 (Thyia, Kastalios). 146 (Amazons); see also heroes, Satyrs, Silens

names, theophoric: 34. 58. 100. 146. 220; related to cults / rituals: 34; Mysta 92; Telestas 24

Neopythagoreans: 173

Near East, Near Eastern parallels: 67.76

Nereids: 7

Nymphaion: 90. 94; see also deities

oath: $19,25.35,221$

oikistes: 71

oil: 212

oracles: $35.67 .79 .84 .110 .111,160.179 .187$

orgiastic cults: 77,150

Orphics, Orphism: 76. 192. 223. 232. 245

personifications: see deities (Dikaiosyne Homonoia, Hosios Dikaios, Nemesis, Nike, Themis, Tyche)

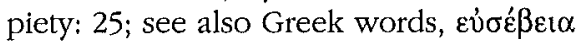

politics and religion: $25,43.79 .97 .99 .115,164.188 .191,211$

pollution: 50.64

prayer: 13.25 .229

priests: $12.13 .25 .26 .92 .100 .103 .104,140,160,161.185 .211,221,244$; eponymous: 12. 92; families of p.: 160, 244; hereditary: 100. 126; for lifetime: 12.25 .10$. 146. 160. 161, 244; high priests: 12.13 .105 .146 .160 .161 .185 ; high priests / 
priestesses of Asia: 40. 96. 148. 244; synods of p. in Egypt: 12. 13. 19. 23. 202; priestesses: 25. 50.61. 79. 96. 100. 109. 118. 126. 140. 146. 160. 161. 189. 206. 220 ; virgin p.: 126. Other cult officials: agonotbetes 16, 221. 243. 244; arcbierotbytes 160; diabetria 220; epimeletes 213 ; bierokeryx 154 ; bieromnemon 29. 61. 159. 211; bierophylax 61; bieropbantria 160; bieropoios 13 . 224; bieropsaltes 12; bierothytes 61. 119. 160. 211. 243; bosioi 152; bypophetes 187; bypotaktikos 186; keryx 25; kistiokosmos 221; lesonis 13; panegyriarches 25; pastopboros 13; phrontistes 13; propbetes 185; prostates 10. 13. 221; cf. 187 (prostasia); pyrphoros 125; stephanephoros 26. 146. 230; synagogos 13

procession: 25. 64. 92. 106. 110. 213

punishment, divine: $13,25.84,172.174 .185 .218$; see also confession inscriptions, funerary imprecations

purification, purity: 50.67

rider gods: 111.117 .185

rituals: arkteia 6

royal cult: $12,13.23,27,88.93 .97 .202$

sacrifice: 12. 17. 25. 27. 28. 43. 92. 106. 119. 154. 165. 169, 201. 213. 229

sacrilege: 46 (stealing of a statue)

sanctuaries: 1.12 .19 .24 .52 .53 .85 .94 .106 .107 .114 .129 .224 . 229; accomodation in 24. 25. 94; accounts 31. 35. 224. 235; administration 31; boundaries of 119 . 164. 165. 169; extra-urban 85; finances of 3. 26. 35. 52. 78. 106. 107. 119. 129. 152. 210. 224; fines payable to 25. 64. 103; inventories of 1.35 .90 .130 ; land of 3. 25. 26. 107. 119; livestock of 106; privileges 12; probibitions with regard to s. 12 . 25; shops in 12. 210; treasures / treasuries 32. 35. 138; see also leges sacrae

Satyrs: 63

Silens: 56.80

skene: 122

slaves: 92.210 ; sacred: 13.25 (hieros). 100

soul: 185.223 .245 ; psychostasia: 185

statues, of gods 12. 13. 25. 35. 46. 67. 84. 90. 100. 110. 140. 151. 164. 178. 182. 200. 240; aniconic 121; apotropaic 67. 84. 178; annual dedication of imperial s. 45; bringing of 84; carrying away of 178; crowning 12. 25; gilding 103

stephanephoria: 12

stones: 67. 121. 122. 238; see also baetyls, gems

superstition: 20

supplication: 210 ; see also asylia

syncretism: $13.15,66.83 .227$

theoria: 9.87

theurgists: 110.111

torch-races: 25.169

trees: see groves

tribes, named after deities: 146

trumpet: 154

underworld: 13.14 .110 .133 .173 .192 .223 .232 .245 ; see also death, funerary cult virginity: 172; virgin goddesses: 84. 185; virgin priestess: 126

'voodoo dolls': 76.84

vows: 25.109 .145 .185 .186 .242

water: $74,85,114.212$ 
weather: 74

wedding: 6

wine: 232

wishes: 20. 155

women: $6.25 .36 .50,68.118 .122 .189 .206 .229$; see also priestesses

wreaths (crowns, garlands): 12. 25. 55. 84. 95

\section{Greek words}

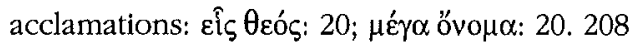

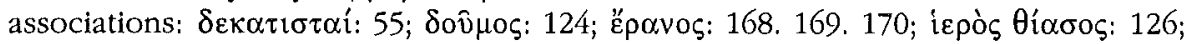

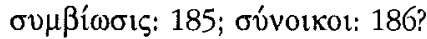

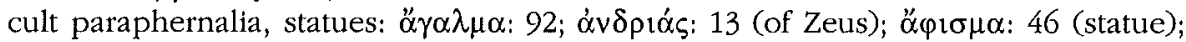

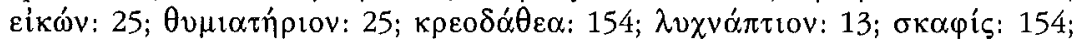

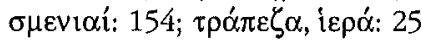

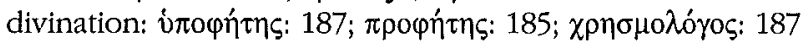

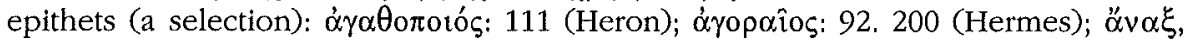

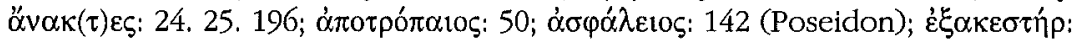
137 (Zeus); érńkoos: 13. 100. 101. 105. 111. 113. 117. 126. 138. 242 (Agdistis,

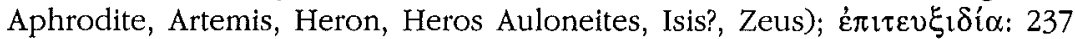

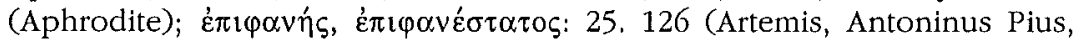

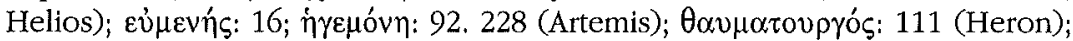

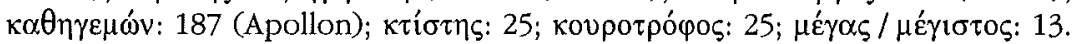
15. 25. 181 (Apollon, Helios Isis, Ptensenes, Sarapis, Zeus Helios Sarapis); $c f$.

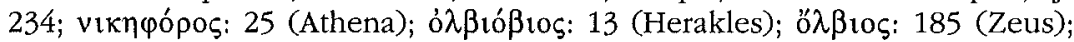

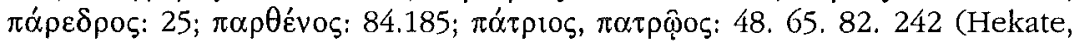

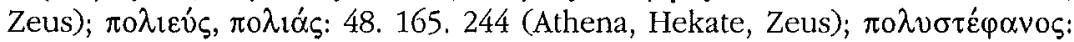

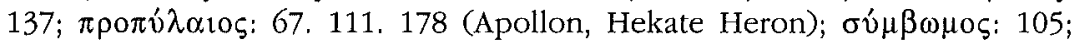

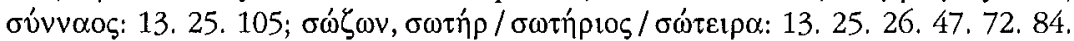
93. 111. 132. 137. 142. 165. 169. 187. 205. 208 (Apollon, Artemis, Atargatis, Athena, Augustus, Boubastis, Hekate, Heron, Ptolemy I, Zeus); cf. 234;

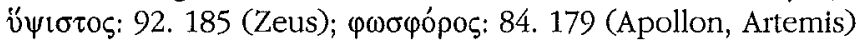

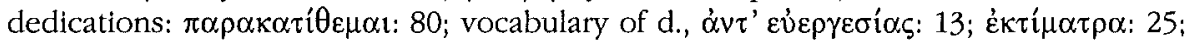

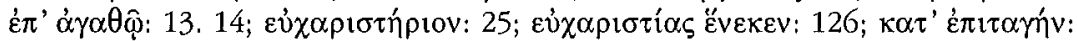

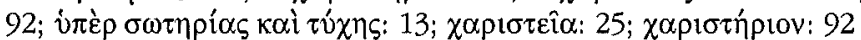

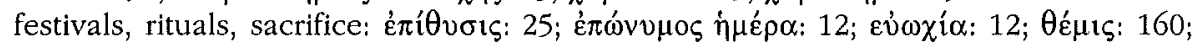

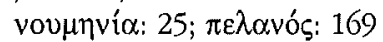

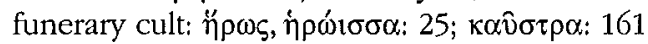

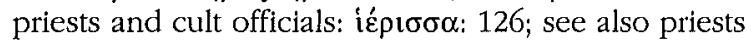

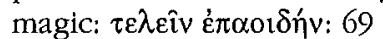

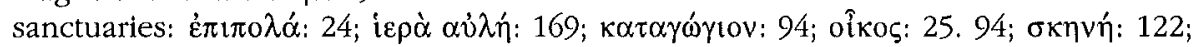

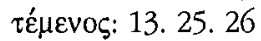

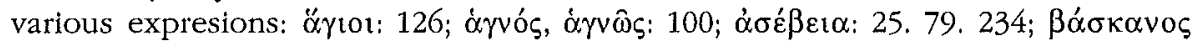

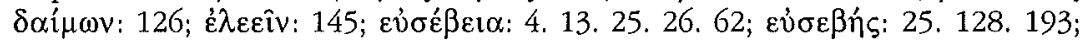

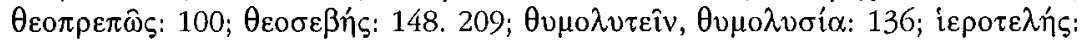

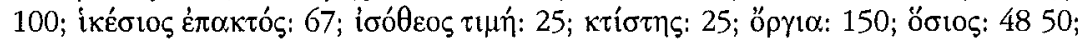

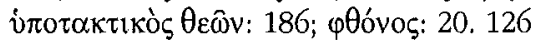


1) S. AlESHIRE, The Economics of Dedication at the Athenian Asklepieion, in Economics of Cult, p. 85-98 [BE 1993, 37]: A. extracts from the inventories of the Athenian Asklepieion evidence concerning the social status of the dedicants and the production of the dedications. She demonstrates that the dedicants were a very heterogenous group and did not belong only to the lower strata of the Athenian population, as is widely believed. The fact that the small votives usually have a standard weight $(1,2,4,5$, or 8 drachmas) implies that they were prefabricated by the silversmiths and offered for sale ready-made. Only the dedications with a greater weight (above 10 drachmas) were ordered by the dedicants.

2) P. AMANDRY, Ou était l'omphalos?, in Delphes, p. 177-205 [BE 1993, 64]: The epigraphic evidence (p. 193-195) implies that the omphalos was located in the temple of Apollon Pythios. A.'s detailed study of the sources suggests a location in the opisthodome, and not in the adyton.

3) C. AMPOLO, The Economics of the Sanctuaries in Southern Italy and Sicily, in Economics of Cult, p. 25-28: A. studies the ownership of land through sanctuaries in Southern Italy and Sicily, esp. in Herakleia and Lokroi, where the size of the sacred property must have been considerable. These sanctuaries applied two different kinds of leases of land, i.e., both perpetual leases and 5-year contracts; the rent was not paid in money, but in barley. [For a similar practice in the Heraion of Samos see infra $\mathrm{n}^{\circ}$ 78. According to A. the fragmentary text SEG 27, 657 (Kamarina, 5th cent.) concerns this procedure; see, however, L. DuBoIS, Inscriptions grecques dialectales de Sicile, Rome, 1989, p. 202-204 $\mathrm{n}^{\circ}$ 177]. A. demonstrates that "public sanctuaries were ruled by thinking about food-supply problems" and that "temple estates seem to have been included in responses to risk and crisis in the food supplies of the Greek cities" (p. 27).

4) V.I. AnASTASIAdis - G.A. Souris, Theophanes of Mytilene. A New Inscription Relating to bis Early Career, in Cbiron, 22 (1992), p. 377-383 [BE 1993, 382]: Ed. pr. of an honorific decree for the historian and politician Theophanes of Mytilene (before $67 \mathrm{BC}$ ).

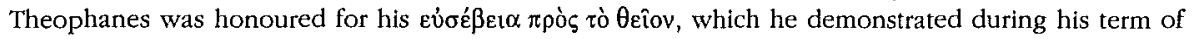
office as prytanis.

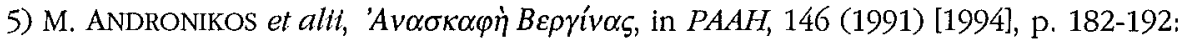
A fragmentary inscription found in the sanctuary of Eukleia seems to be a dedication to the

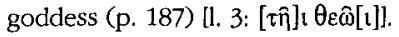

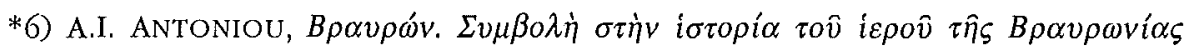

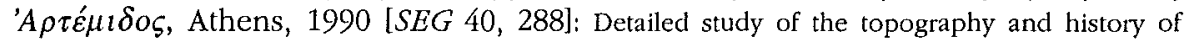
Brauron, with a collection of the literary sources and reference to the still unpublished epigraphic testimonia. The largest part of the book treats the sanctuary of Artemis at Brauron, which was probably abandoned during the Chremonidean War (p. 145-171), the local cults (Artemis, Iphigeneia, Apollon, p. 172-191, 206-214), the nature of Artemis as a goddes of birth and wedding, the festival Mikra Dionysia (p. 215-218), and the ritual of the arkteia (p. 192-205, interpreted as an initiation ritual of girls before the marriage) [on the arkteia see now $E B G R$ 1990, 241]. In an appendix (p. 227-253) A. studies the analogous cults of Artemis in Athens (Akropolis), Piraeus (Mounychia), Stymphalos, Amphipolis, Crete (cave of Arkoudia), Kyrene, and Syros.

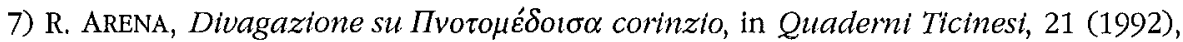

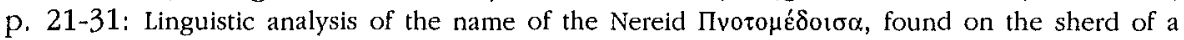
Corinthian vase. A. endorses R. WACHTER's view (SEG 40,1616) that the scribe had a poetic source.

8) P. BALATSOS, Inscriptions from the Academy, in ZPE, 86 (1991), p. 145-154 [SEG 41, 37]: Ed. pr. of 16 inscribed tablets of schist, with holes for suspension, found in the area of the Academy in Athens. Some of the tablets are inscribed with the names of gods (1: Athena, Ares, Artemis, i.e., an alphabetically arranged list of gods?; 4: Artemis?; 7: Hermes; 11a: Sar[pedon?]). These texts were probably exercises of schoolchildren, written in the late 5 th cent. $\mathrm{BC}$. 
9) M. BARBAnERA, Ancora sulla stele funeraria di Antipatros di Ascalona: Una mesa a punto, in Quaderni Ticinesi, 21 (1992), p. 87-103 [BE 1993, 92]: A close study of the relief on the grave stele of Antipatros of Askalon [cf. EBGR 1990,33] shows that the representation corresponds to the text of the epigram. Antipatros was killed by a lion, but his friends were able to bury his body. Antipatros died while serving as member of a sacred embassy of Askalon to a Greek sanctuary (Delos?).

10) G. BASTIANINI - C. GALlazi, Un'iscrizione inedita di Tebtynis e la synodos di Doryphorus, in ZPE, 89 (1991), p. 44-46 [BE 1992, 569; SEG 41, 1638]: Ed. pr. of an

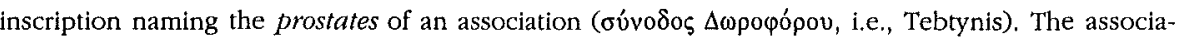
tion was probably named after its founder, whom B.-G. identify with Doryphoros, a libelis of emperor Nero. The association may have comprised leaseholders of land belonging to Doryphoros.

11) A. BÉLIS, Corpus des inscriptions de Delphes. III. Les Hymnes à Apollon, Paris, 1992 [BE 1993, 271]: Reedition with exhaustive commentary of the two hymns to Apollon, with signs of musical notation, written in the Treasure of the Athenians in Delphi. The hymns were written on the occasion of the Athenian Pythais of the year $128 \mathrm{BC}$. The first hymn was composed by Athenaios, son of Athenaios, member of the association of the Dionysiac artists. [Cf. the remarks of J. BOUSQUET, in BE 1993, 271 on several points of B's translation]. [ES]

12) A. BERNAND, La prose sur pierre dans l'Égypte bellénistique et romaine. Tome I: Textes et traductions. Tome II: Commentaires, Paris, 1992 [BE 1993, 653]: Collection of 67 long prosaic inscriptions from Egypt, with texts, translations (vol. 1), critical apparatus, and short commentaries (vol. 2; no new texts). A large group of documents are the decrees of the synods of priests in honour of kings Ptolemy III, IV, and V (8-14, 16-18) [see now $E B G R$ 1990, 104; cf. EBGR 1989, 8 and infra $\mathrm{n}^{\circ}$ 23]. Sanctuaries: Many documents record the granting of privileges to various sanctuaries, esp. the granting of asylia to the sanctuaries of Horus (30, Athribis, 96 BC), Heron (32, Magdola, 95 BC), Isis Sachypsis (31-32, Theadelpheia, 93 BC), Isis (36, Ptolemais, $75 \mathrm{BC}$ ), Isis Eseremphis (37, Theadelpheia, $70 \mathrm{BC}$ ), the crocodile gods Psosnaus, Pnepheros, and Soxis (38, Euemeria, 69 BC), Ammon (39, Euemeria, 69/68), Pnepheros (42-44, Theadelpheia, $57 \mathrm{BC}$ ), and to a synagogue (23, Delta, under Ptolemy VIII). Also notice the correspondence between Ptolemy VIII, the strategos of Thebais, and the priests of Isis regarding the protection of the sanctuary at Philai from abuses of officials (22); a dossier concerning the privileges of the priests of Chnoum at Elephantine (24, ca. 117/115); a letter of the priests of Mandulis to Ptolemy IV with the request of delivery of grain, wine, and wool for the celebration of the sacrifices (19, Philai, 149/8, cf. 20); a decree of the prefect releasing the priests of Soknopaios from impressed labour (54, AD 54). Also notice an honorific decree for Dorion, benefactor of the

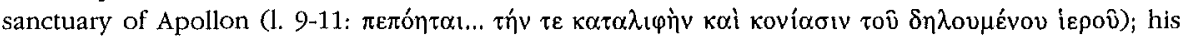
name was to be mentioned by the priests and hieropsaltai in their hymns (25, Memphis, 112/11) [for a similar honour $c f$, infra $\mathrm{n}^{\circ}$ 25]; a foundation for the sanctuary of Soknopaios and Nepherses $(29,97 / 96)$. A freedman, who had built an Aphrodision and workshops nearby, requested ateleia for the brewery he established for the benefit of the sanctuary (51, Menelais, AD 10/12). Festivals: The festival Dionysia and a temple of Dionysos are mentioned in an honorific decree of the association of Dionysiac artists (3, Ptolemais, 269/246 BC); an honorific decree for a gymnasiarch mentions the celebration of the birthday of a king (Ptolemy IV or V) on the 28th Hyperberetaios (15, unknown provenance). An association of farmers honours the benefactor Paris ( $40=S E G 8$,

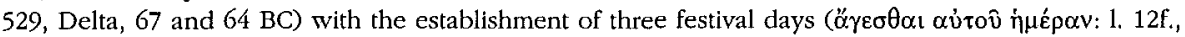
$28,34-37$ ), to be celebrated annually in Alexandria, in the gymnasium, and in the dinning hall donated by him, in the months Thot, Pharmouthi (on the day folowing the day of Apollon), and

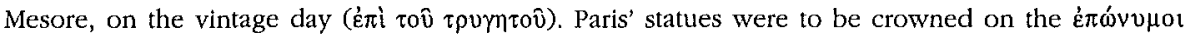

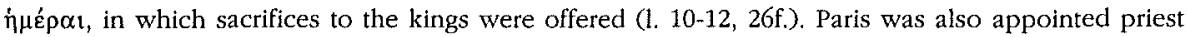
for lifetime; he was to receive a double portion of meat of the sacrificial animals, which was to be sent to him; after his death the association would perform the customary rites on the Nekysia (l. 43f.). An analogous honorific decree of the priests of Ammon-Ra at Thebes $(46,39 \mathrm{BC})$ for their 


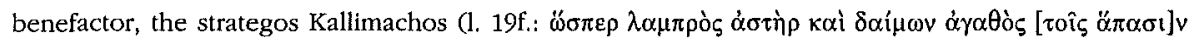

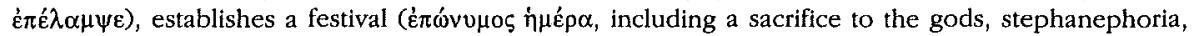

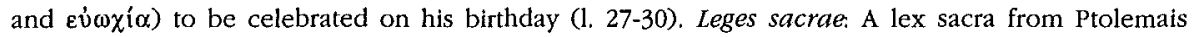
contains regulations about purification before entering a sanctuary $(47=L S S 119,1$ st cent. BC). A fragmentary inscription prohibits the cutting of trees $(28,2$ nd or 1 st cent.). (The imprecation

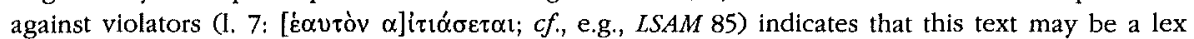
sacra protecting a sacred grove]. The strategos of the Ombites nomos ordered the farmers to keep their pigs outside the sanctuary of Mandulis (63, Talmis, AD 247/8). Also notice the dating formula of a decree with a long list of eponymous priestly offices (26, Alexandria, 112/11); an honorific decree of an association of farmers for their president and high priest for lifetime Apollonios (49, Delta, AD 5); the death of his father, the high priest Theon, is described with the words eiç $\theta$ coù $\zeta$

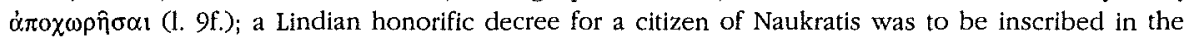
sanctuary of Athena Lindia (1, 5th cent. BC) [on this text see J. BINGEN, in $B E 1993,656$ l.

13) E. BERNAND, Inscriptions grecques d'Égypte et de Nubie au Musée du Louvre, Paris, 1992 [BE 1993, 19, 650, 676]: Corpus of the Hellenistic ( $\left.{ }^{\circ} 1-26\right)$ and Roman $\left(n^{\circ} 27-36\right)$ inscriptions in the various collections of the Louvre Museum, including a few inedita (marked with an asterisk). B. publishes further copies of the honorific decrees of synods of priests for Ptolemy III and V (1*: a new copy of the 'Kanopos decree'; $2^{*}$ : a decree of the year 243 BC; 3; a copy of the decree of the Rosetta stone) [on $n^{\circ} 2^{*}$ see supra $\left.n^{\circ} 23,202\right]$, Festivals: An honourific decree for Antiphilos (5, Ptolemais Hermiou, ca, 246-221) provides for his crowning on 'the day of the king', i.e., the 25th day of every month, a festival commemorating the accession of Ptolemy III to the

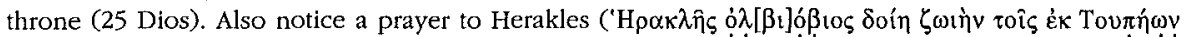

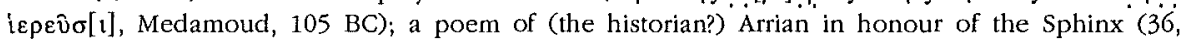
Gizeh). Dedications: To Agdistis Epekoos (8, unknown provenance, reign of Ptolemy II, a temple and a temenos), Aphrodite Thea Neotera (Tentyra, AD 98, a well and a peribolos), Apollon and Kore (26, Hell, an altar; the association of the two gods is unique), Arsinoe Thea Philadelphos $(9$, an altar), Artemis Soteira (7, Kanopos, for Ptolemy I), Augustus identified with Zeus Eleutherios (27), Boubastis Soteira (16, Boubastis, Hell.), Helios Megas Sarapis (34), Hermes and Herakles (12, by a wrestler, winner at the Basileia of Alexandria, Hell.; 17, by a group of young men, $\mu \varepsilon ́ \lambda \lambda \alpha \kappa \varepsilon \varsigma$, Hell.; 13 , of a Ptolemaion and a throne, probably in a gymnasium, Horbeit, ca. $157 \mathrm{BC}$ ), Isis Esenchybis (i.e., Isis of Chemmis) Thea Megiste, Pnepheros, and their synnaoi (20, Hell.), Leto (31, Medamoud), Ptensenes Theos Megistos (15, Edfou, Hell.), Ptolemy VI, Kleopatra II, and the gods of the cataract, i.e., Ammon-Chnubis, Hera-Satis, Hestia-Anoukis, Dionysos-Petempamentis (14, by an association = $\left.E B G R 1989,8 \mathrm{n}^{\circ} 302 ; 1990,127\right)$, the snake gods $\left(35^{*}\right)$, Zeus, Athena, and the politeuma of the

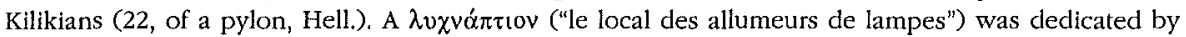
a sick person in the Serapeum of Saqqara (11, Hell.); a person who had been saved erected a statue $(\dot{\alpha} v \delta \rho t \alpha \zeta)$ of Zeus Soterios in the eastern prodomos of a temple $(30 ; c f$. another dedication of a person saved by a god, 117: $\sigma \omega \theta \varepsilon i \varsigma$ ) (on $n^{\circ} 30$ see infra $n^{\circ} 205$ ]. Notice the dedications of Aimos, "a slave of Sarapis and Apis", and Korragos, "a slave of Sarapis and Isis" (25, Hell.); these expressions

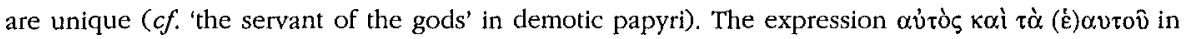
these dedications has been interpreted in different ways: "le dévot place sa personne et ses biens

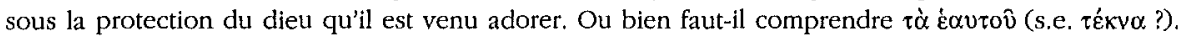
L'auteur de l'inscription peut aussi vouloir dire qu'il est venu en personne au sanctuaire et l'expression $\tau \dot{\alpha}$ É $\alpha v \tau o \hat{v}$ pourrait désigner les offrandes qu'il a faites)" [or that he has dedicated himself and his property to the god]. Grave inscriptions: The epitaph of three sailors, murdered in the harbour

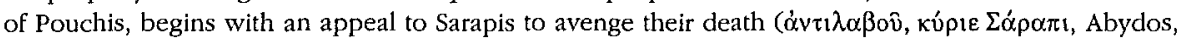
$90=$ OGIS 697); the three persons are represented raising their hands) (for this gesture in prayers of revenge see $E B G R$ 1990, 92]. Another epitaph expresses the hope that the sky will punish those who

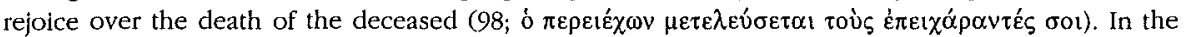

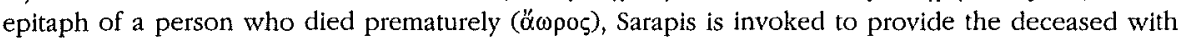

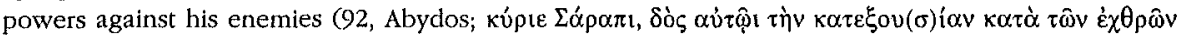
$\alpha$ v่ovi; $c f$. B.'s commentary: "elle émane du ou des survivants qui invoquent la divinité pour que le défunt... puisse agir par-delà la mort contre ses ennemis dont il a peut-être été la victime et qui sont 
toujours ceux de sa famille"). Another metric epitaph (93, Abydos) expresses ideas about life after

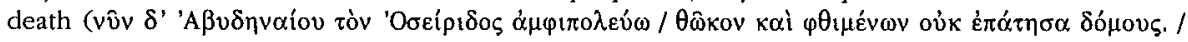

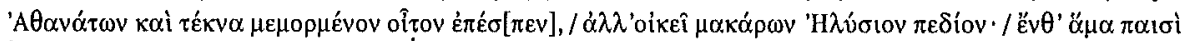

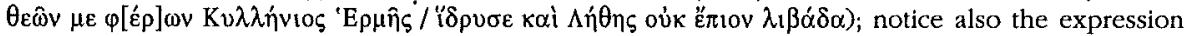
$\Sigma \varepsilon ́ p \alpha \pi t \delta \varepsilon_{\varepsilon} \xi_{\varepsilon}$ name of the deceased in an epitaph (103); cf. another fragmentary invocation of Sarapis (130). Sacred officials: Priests $(1,2,3,8,14,19,32)$, an archiereus (91), an hieropoios (30,

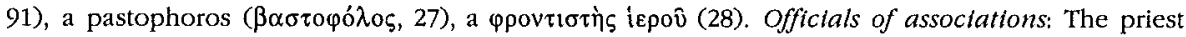
and the archiprostates of an association of soldiers (19, Hell.); the president (synagogos) of an association of worshippers of Isis Sononais (Snonaitike synodos), who also held the office of $\lambda_{\varepsilon \sigma \omega ́} \iota_{\varsigma}$, i.e., administrator of the temple of Onnophris (21, Soknopaiou Nesos, 51 BC); an associa-

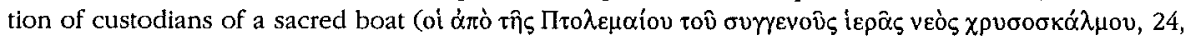

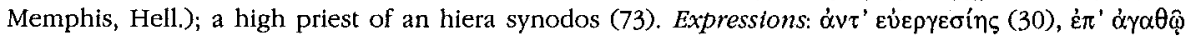

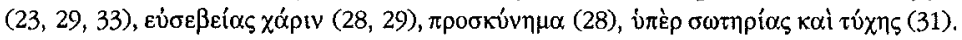

14) E. BERNAND, Sur une stèle d'Abydos copiée par Samuel Sharpe, in ZPE, 91 (1992), p. 217-220 [BE 1992, 574]: Ed. pr. of a grave inscription in the form of a dedication ' $\pi^{\prime}$ $\alpha \gamma \alpha \theta \hat{\varphi}$ (Abydos, AD 85), copied by S. Sharpe (ca. 1837). The relief represents Anubis leading a dead man to the throned Osiris.

15) E. BERnAND, À propos de l'autel dédié à Zeus Soleil, grand Sarapis, par l'arcbitecte alexandrin Apollônios, fils d'Ammônios, au mons Claudianus, in ZPE, 91 (1992), p. 221-225 [BE 1992, 580]: A facsimile by S. Sharpe permits the restoration of the text which records the dedication of an altar to Zeus Helios Megas Sarapis for the welfare of the emperor Trajan (IGR I 1254).

16) E. BERNAND, Dédicace au dieu Héron, in ZPE, 91 (1992), p. 226-228 [BE 1992, 561]: B. offers a detailed commentary of a dedication to Heron Eumenes (Alexandria?, Hell.?, $S B$ I 340). The stele bears a representation of the god (with radiant head) and three snakes, instead of one. The epithet Eumenes is very rare. The cult of Heron came to Egypt from Thrace in the late Hellenistic period. The dedication may have been set up either in a sanctuary of Heron in Alexandria or in the house of a (Thracian?) devotee (cf. CALLIM., epigr, $24 \mathrm{ed}$. Pfeiffer).

17) B. Berquist, A Particular, Western Greek, Cult Practice? The Significance of Stele-Crowned Sacrificial Deposits, in OpAtb, 19 (1992), p. 41-47: B. studies the erection of inscribed and uninscribed stelae on sacrificial deposits, a cult practice which has been observed in the sanctuary of Malophoros in Selinous (from the 7 th cent. on) [for a recent publication see $E B G R$ 1989, 29], in the sanctuary of Hera or Aphrodite in Naxos, and in the 'sacred area' near the temple of Apollon in Metapontion. In Selinous some of the inscribed stelae were dedicated by phratries. Gentilician cults are attested in other Greek areas, too (e.g., in Thasos and Kos), but the practice of erecting stelae on sacrificial deposits seems to be a peculiarity of the Greeks in South Italy and Sicily. These stelae may have been erected in commemoration of sacrificial meals celebrated by the members of gentilician groups.

18) D. BERRANGER, Archiloque et la rencontre des Muses à Paros, in REA, 94 (1992), p. 175-185 [BE 1993, 391]: Mnesiepes' vita of Archilochos, preserved in a Parian inscription, begins with a narration of the poet's encounter with the Muses, who gave him a lyre. B. translates the text and studies the analogies between this episode and Hesiod's poetic 'initiation' (Theog., 2434), esp. the setting of both episodes in an extra-urban location and the presentation of the poets as shepherds, the iconographic tradition of the episode, and the history of Archilochos' cult on Paros. [See already C.W. MÜLlER, Die Arcbilochoslegende, in RbM, 128 (1985), p. 99-151, whose article B. does not seem to know; $c f$. $E B G R$ 1988, 30 with further bibliography; $c f$. also B.'s book Recbercbes sur l'bistoire et la prosopograpbie de Paros à l'époque arcbatque, Clermont-Ferrand, 1992 (non vidi)].

19) J.-M. BERTRAND, Inscriptions bistoriques grecques traduites et commentées, Paris, 1992 [ $B E$ 1993, 6]: Translations of 150 selected inscriptions (archaic-Hell.), with very short commentaries and almost no bibliography. The material is organized chronologically. The 
selection includes passages of the 'Lindian chronicle' (2), the dedication of Pedon (4) [EBGR 1988, 114], the oaths of the colonists of Kyrene (5) [ $f f . E B G R$ 1990, 192] and the Athenian ephebes (18), the letter of Dareios to Gadatas about the asylia of the sanctuary of Apollon in Magnesia (12), many thanksgiving dedications after wars $(13,15,16,21,35,90,104,107)$, the lex sacra regarding the offering of first-fruits to Eleusis (30), a letter of Antiochos III to Zeuxis concerning the administration of sanctuaries in Asia Minor (112) [EBGR 1987, 67], documents concerning a festival in honour of Philopoimen in Megalopolis (125) and the festivals Soteria in Delphi (92, 101), Leukophryena in Magnesia (113), Nikephoria in Pergamon (126), and several decrees of the Egyptian synods of priests $(105,110,117)$. Several texts concern the royal cult in the Hell. period, i.e., the cult of Demetrios established by the Koinon of the Islanders (82), the Athenian honours to Antigonos and Demetrios (84), and the cult of Antiochos I (87), Ptolemy I (88), and Laodike (121).

20) G. BEVILACQUA, Antiche iscrizioni augurali e magiche dai codici di Girolamo Amati (Opuscula Epigrapbica, 2), Roma, 1991: Edition of 49 Greek and Latin inscriptions on gems and metal sheets copied by G. Amato between 1818-1834 and preserved in a manuscript in the Bibliotheca Vaticana. Most of these objects could be identified with objects preserved in various collections and museums (new texts are marked with an asterisk). Several inscriptions on

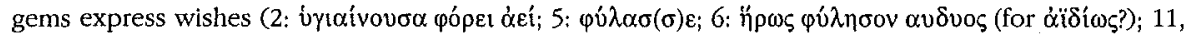

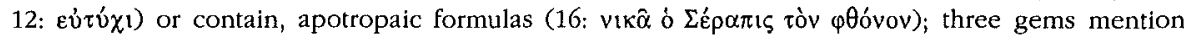
mythological names (12: Telephos; 13: Atalante; 15: Laodameia?). The gnostic gems (17-33) are

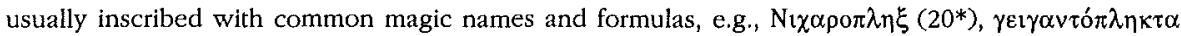
(24*), $\varphi \hat{v} \lambda \alpha \sigma \sigma \alpha(1)$ and magical words (22), $\delta\left\llcorner\alpha \varphi \hat{u} \lambda\left(\alpha \xi_{o v}\right)\left(25^{*}\right)\right.$. Some interesting pieces: 18*: the imperative $\pi \varepsilon ́ \sigma \sigma \varepsilon$, written three times, may be a wish for good digestion; a love-charm (26 1. 5-7:

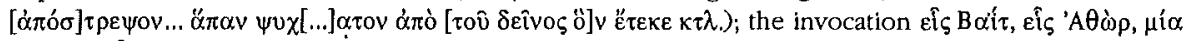

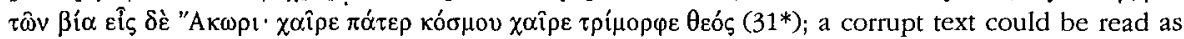

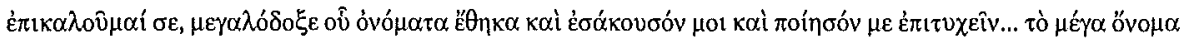

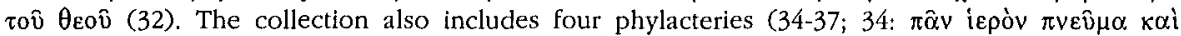

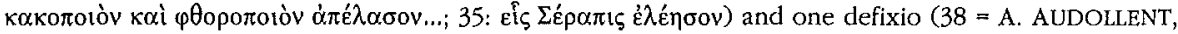
Defixionum tabellae, Paris, 1904, $\left.\mathrm{n}^{\circ} 189\right)$.

21) M. BILE, Les termes relatifs à l'initiation dans les inscriptions crétoises (VII $e_{-}$ Ier siecles av. J.-C.), in Initiation, I, p. 11-18: B. presents the terms related to age classes, the organization of the youth, and rites of passage attested in Cretan inscriptions from the archaic to the Hell. period. Whereas the epigraphic evidence for the $\dot{\alpha} \gamma \varepsilon \dot{\varepsilon} \alpha$ agrees with Ephoros' report of this Cretan institution, there is only indirect epigraphic evidence for the rites of passage described by Ephoros (ap. STRAB., X, 4, 21) [for which there is, however, unequivocal archaeological evidence

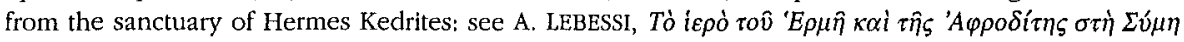

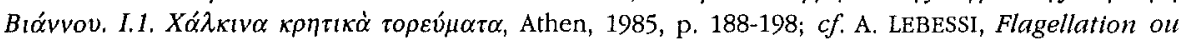
autoflagellation. Données iconograpbiques pour une tentative d'interprétation, in $B C H, 115$ (1991), p. 99-123; on the Cretan festivals of initiation see now D.D. LEITAO, The Perlls of Leukippos. Initiatory Transuestism and Male Gender Ideology in the Ekdusia of Phaistos, in ClAnt, 14 (1995), p. 130-163].

22) M.-F. Billot, Le Cynosarges, Antiocbos et les tanneurs: Questions de topographie, in $B C H, 116$ (1992), p. 119-156: After a detailed study of the literary and epigraphic evidence on Kynosarges, B. makes some suggestions about the possible location of the sanctuary of Herakles. She suggests that the lex sacra LSS 4 [cf. EBGR 1987, 63; infra $\mathrm{n}^{\circ} 35$ ] is related to the sanctuary of Herakles Pankrates [on this sanctuary see now EBGR 1991, $119=S E G 41,247$ and E. TAGALIDOU, Wethreliefs an Herakles aus klassiscber Zeit, Jonsered, 1993, p. 159-165].

23) J. BINGEN, Le décret du synode sacerdotal de 243 avant notre ère, in $C E, 134$ (1992), p. 319-328 [BE 1993, 678]: B. reedits with substantial restorations the decree of the synod of priests preserved in the Louvre Museum [supra $\mathrm{n}^{\circ} 13,2^{*} ;$ cf. infra $\mathrm{n}^{\circ} 202$ ]. This decree was passed by the synod in honour of Ptolemy III, on the day of a festival for the Theoi Adelphoi (Theadelpheia). It can be dated in the fifth year of his reign $(243 \mathrm{BC}$ ); this was the first year in 
which the Theoi Euergetai appear in the title of the eponymous priest in Alexandria. This decree may be the one cited some years later in OGIS 56 (238 BC).

24) D.E. BIRGE - L.H. KRAYNAK - S.G. Miller, Excavations at Nemea. I. Topographical and Architectural Studies: The Sacred Square, the Xenon, and the Bath, Berkeley-Los Angeles-Oxford, 1992 [BE 1993, 61]: Study of the topography and the architectural remains of the sacred square around the temple of Zeus, the xenon, and the bath in the sanctuary of Zeus at Nemea. A catalogue of artifacts (p. 263-304) contains several inscriptions, already published in the reports in Hesperia or in S.G. MILLER, Nemea: A Guide to the Site and Museum, Berkeley, 1990, i.e., an altar of Zeus Ensitarchios, i.e., in the Grain Office $\left(\mathrm{n}^{\circ} 100\right.$, p. $249 \mathrm{f} .=$ $S E G$ 30, 531), dedications to Ephodia (Artemis or Hekate, $\mathrm{n}^{\circ}$ 5, $c f$. p. 2 , probably from the Sacred Square), Zeus Kronion Anax (25, by Aristis from Kleonai, four times victor at pankration at the Nemea, arch.), two roof tiles stamped with the text Nemeiou and a ligature $\left(n^{\circ}\right.$ 98-99). The area called Epipola, mentioned in a boundary stone $\left(n^{\circ} 22, p .97 f\right.$.) may be identified with the Sacred Square ( $c f$. SCHWYZER $\mathrm{n}^{\circ}$ 89). Inscribed pillars in the xenon demarcated rooms belonging to the Epidaurians and the Rhodians ( $n^{\circ} 26$, p. 186). Also notice the name Telestas inscribed on a block in the xenon (27).

25) W. BLÜMEL, Die Inschriften von Knidos. I (IGSK, 41), Bonn, 1992 [BE 1992, 456]: The corpus of the inscriptions of Knidos and its territory contains many new texts (marked with an asterisk). According to the principles of this series, B.'s commentaries are usually very short. Knidos (Tekir): Dedications: In a metrical dedication written on the base of a statue of Hermes, dedicated by the the prostatai of Neapolis $(21,4$ th cent.), the god greets the magistrates, explaining

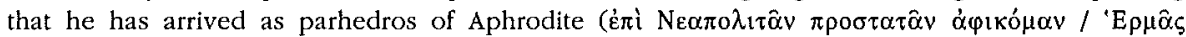

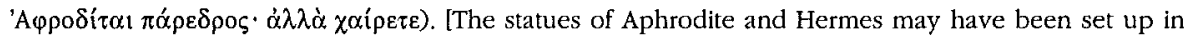
the seat of the prostatai; these two gods are often regarded as protectors of magistrates: see, e.g., EBGR 1991, 194]. Statues of Caesar (41*, ca. 48 BC), Nero Claudius Drusus (43*, late 1st. cent. BC), Roma $\left(88^{*}\right)$, the proconsul P. Vicinius $\left(87^{*}\right)$, and many prominent citizens $\left(51^{*}, 52^{*}, 81^{*}, 82^{*}, 83^{*}\right.$, $\left.84^{*}, 85^{*}, 86^{*}, 89^{*}, 90^{*}, 91,94^{*}\right)$ were dedicated to the gods by the demos, sometimes also by private persons (statues of various Knidians and foreigners: 111, 112, 113*, 114*, 115, 116*, 118*, 125*). Other dedications are addressed to Agathe Tyche (187, Hell.), Aphrodite (162, Hell.), Apollon $\Lambda \alpha \tau o^{\prime} \delta \alpha \varsigma$ (163*, a tripod, Hell.), Apollon Karneios (164*, 165, Hell.), Apollo Pythios (169), Apollon Pythios Latoidas (170*), Artemis Hiakynthotrophos Epiphanes (171, 2nd cent. BC), Asklepios (172, 3rd cent. BC), Athena $\left(173^{*}, 174^{*}, 175,176^{*}, 178\right.$, Hell.), Athena Nikephoros and Hestia Boulaia

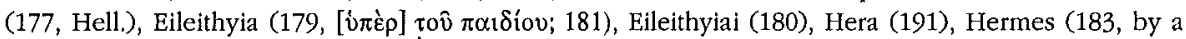
damiourgos), Kourotrophos (192, 193*, Hell.; 495 from Barkaz), Merops (?, 184*), the Muses (185), Nymphai Pedieis [or Pedieon] (194*, Hell.), Sarapis, Isis, and all the gods (186, Hell., after a cure by a man from Alexandria), Zeus Meilichios (188, altar), Zeus Soter (189*, imp.), the gods (190, a Өvóeı $\left.\beta \omega \mu \delta_{\zeta}\right)$. A statue of a man who had participated in the agon at Karnea $(\kappa \alpha \rho v \varepsilon \alpha \delta \rho \circ \mu \eta \dot{\sigma} \sigma \nu \tau \alpha)$ was erected near the great altar of the sanctuary of Apollon Karneios (165, 2nd cent. BC) [ $=E B G R$ 1990, 226]. Leges sacrae: A prohibition of lodging in the sanctuary of Dionysos Bakchos $(160=$ LSAM 55, late 4th cent. BC); a fragmentary decree concerning sacrifices to Aphrodite (161*, $3 \mathrm{rd} / 2 \mathrm{nd}$ cent.). $\left[N^{\circ} 173^{*}\right.$, according to $\mathrm{B}$. a dedicatory inscription to Athena, may be the fragment of a lex sacra, as the verb $\theta \dot{v} \varepsilon[v$ ? $](1.4)$ implies; on 1.2 read Znvò [s]]. A large dossier of texts concerns the local benefactor, scholar, and friend of Caesar C. Iulius Theopompos (51-61). Statues of Theopompos were dedicated to Apollon Karneios by his friend Apollonios (57) and by the Roman residents of Knidos (701). Several members of his family (his wife Telesteira, his daughter Nosis, and his sons

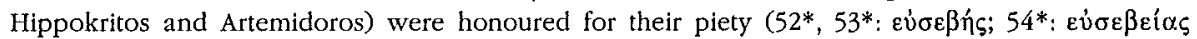

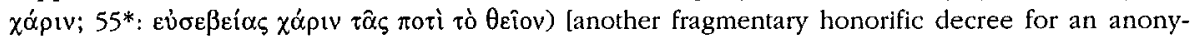

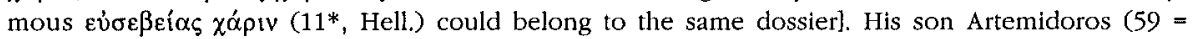
$S G D I$ 3502), priest of Artemis Hiakynthotrophos Epiphanes for lifetime, was honoured with a public

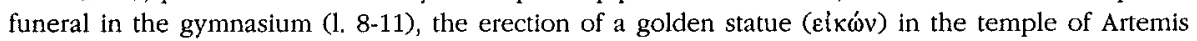
Hiakynthotrophos Epiphanes, and divine honours as synnaos of Artemis (1. 11-15); the city founded an altar for Artemidoros and the festival Artemidoreia, which included a sacrifice, a procession,

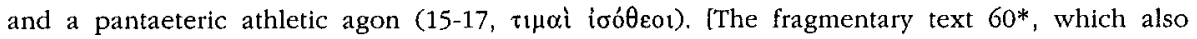


concerns Artemidoros, mentions golden and marble statues. The words $x \alpha \tau^{\prime}$ évi $\alpha v \tau$ óv imply that these statues were decorated with garlands annually, during a festival (1.5)]. Two condolence decrees (71-72, 1st/2nd cent.) mention honours for the deceased persons (including public funerals). The honorific decrees for Lykaithion (73-75) mention that her name and the name of her husband were to be mentioned by the damiurgos in the sacrifices offered at the beginning of the

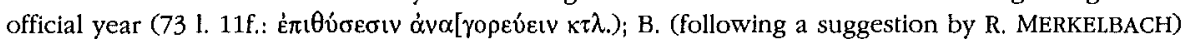
interprets éní $\theta v \sigma i \varsigma$ as 'Einführungsopfer'. [For a similar honour $c f$. supra $\mathrm{n}^{\circ} 12$ ]. Another honorific decree was to be announced in the Dionysia (74). Sacred officials: Aurelia Eirene, wife of the priest

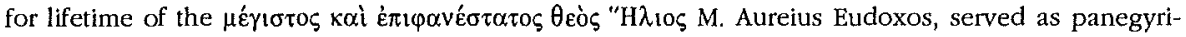

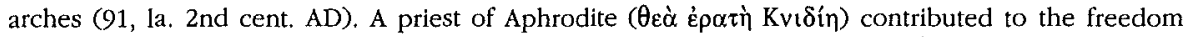

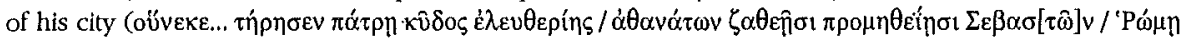

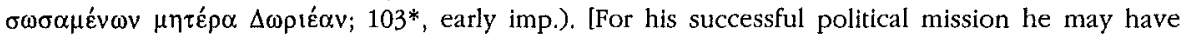
exploited the connection of the Julii with Venus/Aphrodite, which was exploited in the same period by Aphrodisias]. A priest of Dionysos is mentioned in $n^{\circ} 113^{*}$ (Hell.). Also notice the expression

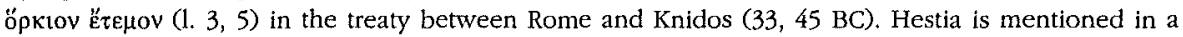
fragmentary decree $\left(36^{*}\right.$, imp.). [It may concern transactions or commercial activities; cf. 1. 6 ( $\varepsilon^{\prime} v$

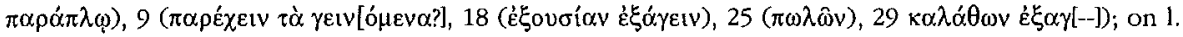

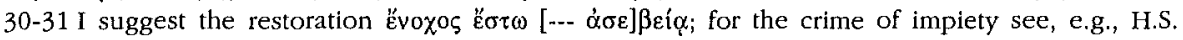
VERSNEL, infra $\mathrm{n}^{\circ} 234$, p. $123-131$. Hestia, mentioned in the next line, is possibly the recipient of a fine; for fines payable to sanctuaries cf. infra $\mathrm{n}^{\circ}$ 64]. Augustus is regarded saviour and ktistes (42*); a person is honoured for providing food for the hieral trapezai for 6 months $(115, \sigma i \tau \varepsilon v \sigma \alpha v \tau \alpha$

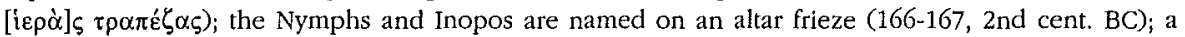
thymiaterion bears the inscription $\theta \varepsilon o \hat{\zeta} \lambda \alpha \beta \varepsilon$ ' (195); the Parian sculptor Bulis made the statues 'from

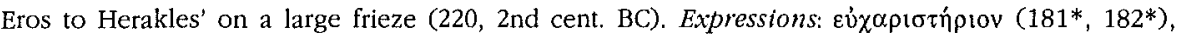
$\chi \alpha p i \sigma \tau \varepsilon i \alpha$ (186). Grave inscriptions: A funerary imprecation (461*) mentions a fine and the formula

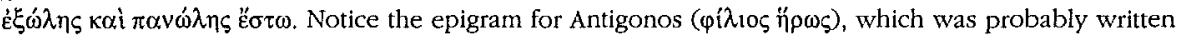
in a gymnasium (301, 3rd cent. BC), and the grave inscriptions of a winner of the Aspis of Argos

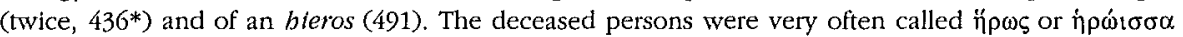
$(311,313,316,317,319,320,321,324,326,329,335,372,397,408,411,425,426,427,429,430,511,512$, $632,642,804)$.

The inscriptions from the temenos of Demeter and Kore (131-159, no new texts, 4th-2nd cent. BC) include a metrical dedication of Chrysina, who, in a dream, was ordered by Hermes to dedicate an oikos and a statue to Kore and Demeter at the site Tathne $(131=C E G 860$, 4th cent. BC). Dedications: To Kore (132, 143, by priestesses), Demeter (134, 142, 145, 146), Demeter and Kore

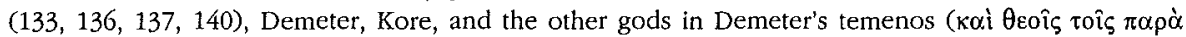
$\Delta \alpha \mu \alpha \tau \rho t, 135,138)$ [for $\pi \alpha \rho \alpha$, the name of a god in dative in the meaning of 'in the sanctuary of cf. P. CHARnEUX, Du côte de chez Hêra, BCH, 111 (1987), p. 207-223l, Demeter, Kore, Plouton, the hero Epimachos, and Hermes (141), the Anakes (139). One dedication is called $\chi \alpha \rho \jmath \sigma \tau \varepsilon \hat{\alpha} \alpha$ k $\alpha$ i

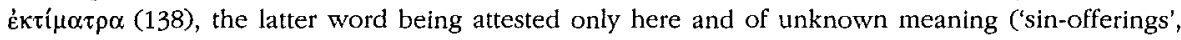
penalties', 'thanksgiving for manumission', 'dedication in expression of great reverence'). The most important texts are the well-known defixiones of women $(147-159,2$ nd/1st cent. BC, no new texts or

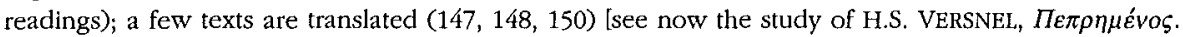
The Cnidian Curse Tablets and Ordeal by Fire, in R. HÄGG (ed.), Ancient Greek Cult Practice from the Epigraphical Evidence. Proceedings of the Second International Seminar on Ancient Greek Cult, Organized by the Swedish Institute at Atbens, 22-24 November 1991, Stockholm, 1994, p. 145-154].

Knidian inscriptions found in other areas (211-221) include dedications in Delphi (211-213), graffiti on vases found in the sanctuary of Apollon Milasios in Naukratis (214-216, 6th cent. BC), a dedication of Mikos from Magnesia to Athena in Lindos written with Knidian characters (217, 6th cent. BC), decrees of Knidos concerning the Leukophryena in Magnesia (219) and the festival of Artemis Hiakynthotrophos in Knidos (220, ca. 200) [EBGR 1987, 90], and a decree about the lawsuit between Kalymna and the sons of Diagoras of Kos, containing the oath of the judges; the judges 
invoked Zeus, Apollon Lykios, and Ge and took their oath on burning sacrificial animals (221 1. 2632 , ca, $300 \mathrm{BC}$ ).

Inscriptions of foreign cities found $1 \mathrm{n}$ Knidos include a decree of Samothrake mentioning an agon (233*, Hell.) and a condolence decree of the international association of athletes for the death of Euboulos, who received heroic honours $(234,1$ st $/ 2$ nd cent. AD).

Inscriptions from the territory of Knidos: A text from Betce concerns the temenos of Asklepios; the revenues from the leasing of the sacred land would be spent for the sacrifice $(502,4 \mathrm{th} / 3 \mathrm{rd}$ cent). The inscriptions from Datça/Burgaz (old Knidos?) include dedications to the Dioskouroi (601, ea. 6th cent. BC), Aphrodite and Peitho (612, 4th/3rd cent.) [on their cult see $E B G R$ 1991, 194]. A benefactor $(606,2 n d / 1$ st cent. BC) was honoured with prohedria at the Dionysia and Hiakynthotrophia (1. 3-4), a public funeral in the city (1. 7-9), and an annual sacrifice on the first day of a certain month (1. 8-12). [Since this annual sacrifice is mentioned immediately after the funeral, perhaps it was to be offered on the first day of the month in which the benefactor would die, i.e.,

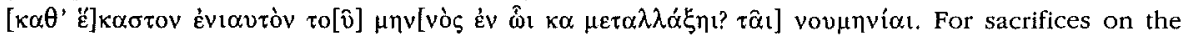
anniversary of a person's death cf. infra $\mathrm{n}^{\circ}$ 143]. The herald was to pray for him and for his descendants on the Dionysia and the Hiakynthotrophia (1. 12-14); a torch-race was organised to honour him (1. 16-22).

26) W. BLÜMEL, Neue Inschriften aus Mylasa (1989-1991), in EA, 19 (1992), p. 5-18 [ $B E$ 1993, 513]: Ed. pr. of 17 inscriptions from Mylasa. A fragmentary record of sale (217 B, la. 2nd cent. BC) concerns land bought by the elected ktematonai of the tribe of the Otorkondeis on behalf of Zeus Otorkondeon (1. 8); this land bordered the sacred land of Zeus Osogo (1. 11). The eponymous stephanephoros was adopted son of a priest of Sinyri, who is also mentioned as owner of land bordering the sacred land (1. 15); a priest of Zeus Ktesios is mentioned among the proprietors whose land bordered the sacred land of Zeus Otorkondeon (1. 12). $\left[\mathrm{N}^{\circ} 352\right.$, a fragmentary decree of the Otorkondeis (2nd/1st cent. BC) may also concern the purchase of sacred land. The Otorkondeis declare their $\varepsilon \dot{v} \sigma \varepsilon \varepsilon_{\beta} \varepsilon 1 \alpha$ towards Zeus, Savior and Benefactor of their tribe, and probably

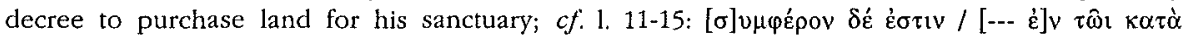

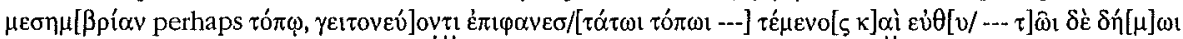
$\dot{\varepsilon} \pi[/--\tau] \grave{\eta} v \pi \rho o ́ \sigma o \delta o v \kappa \tau \lambda$.]. Also notice two dedications (353, by a priest of Homonoia, Hell.; 354), a gravestone dedicated to Daimones Agathoi (499, imp.), a priest of the emperor cult (607), and several new fragments of decrees of Cretan cities, which recognized the city of Mylasa as immune and sacred $(660-663,2$ nd cent. BC).

27) W. BlüMEL, Brief des ptolemäischen Ministers Tlepolemos an die Stadt Kildara in Karien, in EA, 20 (1992), p. 127-132 [BE 1994, 528]: Ed. pr. of a letter sent by Tlepolemos in response to a visit of envoys from Kildara. This letter shows that Kildara supported Ptolemy III and Antiochos, the son of Antiochos II and Berenike, at the beginning of the Laodikeian War (246

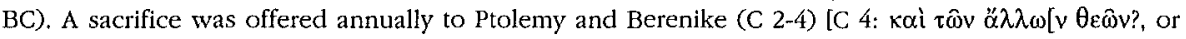

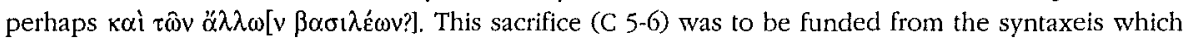
Kildara had to pay previously [on this point see Ph. GAUTHIER, in $B E 1994,528$ ]. Seven days [presumably during the festival in honour of Ptolemy] should be ateleis (D 1). [The phrase [ $\theta$ ]voíav

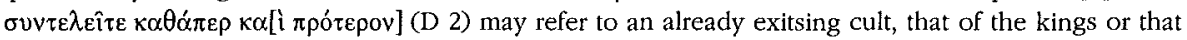
of a local deityl.

28) A. BOEgEHOLD, Two Graffiti from Ancient Corinth, in Hesperia, 61 (1992),

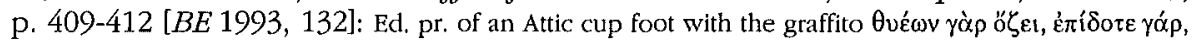
i.e., 'in fact it smells of sacrifices; yes, add to it' (Korinth, ca. 550-500 BC). This graffito seems to reproduce a dialogue, not necesserily a literary quotation.

29) J. BousQueT, Inscriptions de Delpbes, in BCH, 116 (1992), p. 177-196 [BE 1993, 248,274 ]: B. publishes three new honorific decrees for Chian hieromnemones (p. 187f., $c f$. FdD III $3,212-229$ ) and two new inscriptions containing quotations from tragedies (p. 183-186, 4th-3rd cent.); the more extant fragment is related to the myth of Meleagros [for quotations of literary texts in inscriptions of. A. CHANIOTIS, Historie und Historiker in den griechiscben Inscbriften, 
Stuttgart, 1988 , p. 284f. $\left.n^{\text {os }} 55,56,58,61\right]$. B. also publishes a few new and restores already published agonistic inscriptions (p. 188-196).

30) J. BOUSQUET, Deux épigrammes grecques (Delphes, Ambracie), in BCH, 116 (1992), p. 585-606 [ $B E 1993,273$; $S E G$ 41, 540]: A new fragment of $F d D$ III 1,510 permits the restoration of an epigram on the base of the statue of the Athenian Kallias III, who won the Pythia, the Nemea (twice), and the Isthmia (Delphi, ea. 4th cent.). B. also reedits, with commentary, the epigram $E B G R$ 1991, 5 (Ambrakia).

31) J. BOUSQUET, L'administration du sanctuaire de Delphes au IVème siècle av. J.Chr., in Cabiers du Centre G. Glotz, 3 (1991), p. 21-29 [BE 1992, 277]: Short presentation of the evidence gained from the accounts of Apollon's sanctuary at Delphi about the administration of the sanctuary in the 4th cent, and the institutions of the Amphictiony. [ES]

32) H. BRANDT, IG IV 554: Aus Argos oder Halieis?, in Chiron, 22 (1992), p. 83-90: The bronze tablet $I G$ IV 554, which concerns the treasury of a sanctuary of Athena, has been attributed by M.H. JAMESON to Halieis; B. defends its provenance from Argos.

33) W.M. BRASHEAR (with contributions of A. BÜLOW-JACOBSEN), Magica Varia (Papyrologica Bruxellensia, 25), Bruxelles, 1991: Edition of 6 magical papyri and an octagonal crystal prism (p. 80-84). Each side shows an engraved standing human male or alektryocephalic figure, holding an object in both hands. The spaces above and below the figures are covered with pseudo-letters and cryptographic symbols. This object may have been used for divinatory purposes.

34) C. BRIXHE, Etymologie populaire et onomastique en pays bilingue, in RPh, 65 (1991), p. 67-81 [BE 1994, 585, 601; SEG 41, 1788]: B. studies the adaptation of non-Greek personal names in southern Asia Minor. Some of the indigenous names were hellenized in such a way that they could be associated etymologically with Greek words. "Oßpt $\mu$ os, e.g., a common name in Kolybrassos, secondarily associated with the adjective of $\beta p \iota r$, is related to the epiklesis uppara

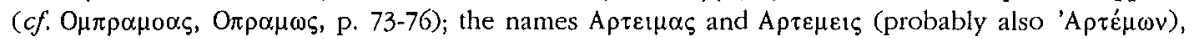
common in Termessos, were probably of Anatolian origin, only later associated with the cult of

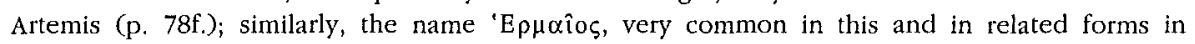
Termessos, derives from the name of the Hittite and Luwian moon-god Arma (p. 78f.).

35) K. BRODERSEN - W. GÜNTHER - H.H. SCHMITT, Historische griechiscbe Inschriften in Übersetzung. Bd. I. Die archaische und klassische Zeit, Darmstadt, 1992 [BE 1993, 5]: Selection of 154 translations of inscriptions, with short bibliography and no commentaries. Leges sacrae: A lex sacra of Delphi $(46=\operatorname{LSCG} 76)$, the Athenian leges sacrae about the cult of the Nymphs $\left(86=\right.$ LSCG 178), the temenos of Herakles $\left(87=\right.$ LSS 4) [cf. supra $\mathrm{n}^{\circ} 22$ ], the priestess of Athena Nike $(75,120=\operatorname{LSCG} 12)$, and the offering of first-fruits at Eleusis $(123=\operatorname{LSCG} 5)$, the treaty betwen Delphi and Phaselis about the payment of charges for the consultation of the oracle $(116=$ LSS 39). Accounts - inventories: An account from the Nemesis sanctuary at Rhamnous ( $67=I G \mathrm{I}^{3}$ 248 , 5th cent.), the accounts related to the construction of Athena's statue (91), the accounts of the Delian temples (93), the building accounts of the Parthenon and the Propylaia (94, 95), the accounts of the treasurers of Athena (142), the inventories of the Parthenon (126), the Hekatompedos (127), and the Pronaos (133). Finances of sanctuaries: A document concerning a private loan from the sanctuary at Tegea (73), Athenian documents about loans and payments from sacred treasuries $(92,112,128,141)$, an Athenian document related to the financial administration of Delos (143). Oaths: The oath of the colonists of Kyrene (6), the 'oath of Plataia' (40). The selection also includes many dedications $(5,13,14,15,20,21,24,25,28,31,32,33,37,39,42,49,56$, $59,70,83,105,114,151$ ), the letter of Dareios to Gadatas (22), the Spensitheos decree (26), the imprecations of Teos (47) [cf. infra $\mathrm{n}^{\text {os }} 86,197$ ], a decree about the construction of a bridge on the Hiera Hodos (124), and the records of the confiscation of the property of the Hermokopids (132). 
36) A. BRUGNONE, Le leggi suntuarie di Siracusa, in PP, 47 (1992), p. 5-24: B. studies the 'sumptuary laws' of Syracuse (ATHEN., XII, 521 b-c = PHYLARCHOS, FgrHist $81 \mathrm{~F} 45$ ) against the background of socio-political developments (la. 6th/ea. 5th cent.). The prohibitions of expenses and luxurious clothing in Syracuse applied generally, not in a religious context, but they find some parallels in clothing regulations for women in leges sacrae (e.g., prohibitions against $\alpha{ }^{\prime} v \theta_{i} v \alpha$ ).

*37) P. BRulé, Fêtes grecques: Périodicité et initiations. Hyakinthies et Panathénées, in Initiation, I, p. 19-38: A comparative study of the festivals Hyakinthia in Sparta and Panathenaia in Athens in the light of literary and epigraphic sources demonstrates their similarity (mythical background, position in the religious calendar, participation of the entire community, procession, offering of a peplos, integration of the youth in the adult population). Based on this similarity B. argues that the original core of the Panathenaic festival was a 'rite de sortie' for both sexes, celebrated annually.

38) W. Burkert, Perikles von Mylasa, Architekt des Tempels der Venus und Roma, in Kotinos, p. 415-417 [BE 1994, 82]: B. republishes with translation and commentary the grave epigram for Perikles (I.Mylasa 8, ea. 4th cent. AD), who built a great temple in Rome, most probably the temple of Venus and Roma, finished in AD 312. Perikles claimed descent from

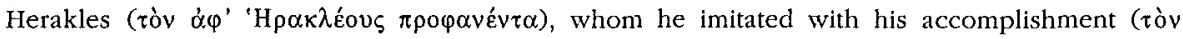

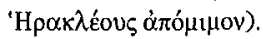

39) M.L. CALDELLI, Curia atbletarum, iera xystike synodos e organizzazione delle

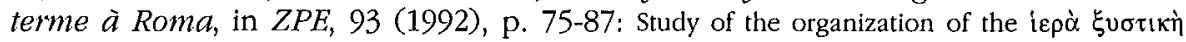

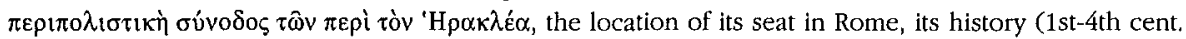
$\mathrm{AD}$ ), its administration, and esp. the responsibilities of the officials xystarcbes and epi balaneion; the latter was probably responsible for that part of the thermae which was frequented by the athletes.

40) M.D. Campanil.te, Un sommo sacerdote del II secolo d.C., in SCO, 42 (1992), p. 277-279: The high priest of the emperor cult in Asia mentioned in I.Ephesos 664b (2nd cent. AD) is Herennius Rufus, who may be identified with a person mentioned in an Athenian inscription (BE 1952, 51).

41) O. CAVALIER, "Rencontre dans une grotte". A propos d'un autel votif grec, in Revue du Louvre, 6 (1990), p. 443-454 [SEG 40, 201]: Ed. pr. of a small altar with a relief representation of Apollon, Pan, and two dancing women in a grotto (Attika?, late Hell.). An Inscription names the two gods and the dedicant. C. discusses in detail the iconographic parallels and argues that this dedication alluded not only to the musical competence of the two gods, but also to their divinatory powers.

42) F. CHamoux, Un pigeonnier antique près d'Apollonia en Cyrénaique, in CRAI, 1992, p. 623-642: C. reports the discovery of a columbarium at Apollonia, the hatbour of Kyrene (imp.?). After a detail study of parallels $C$. argues that this columbarium was a public monument, probably erected in a sanctuary, and presents the literary and epigraphic evidence for the relation of pigeons to certain gods (Aphrodite, Apollon, Demeter, Zeus) and for the dedication of columbaria to gods (esp. a text from Phildelpheia, EBGR 1989, 36].

43) A. Chaniotis, Die Inschriften von Amnisos, in J. SCHÄFER (ed.), Amnisos nach den archäologiscben, bistorischen und epigrapbischen Zeugnissen des Altertums und der Neuzeit, Berlin, 1992, p. 287-323: Reedition of the inscriptions found in the sanctuary of Zeus Thenatas at Amnisos (territory of Knosos) with historical and prosopographical commentary ( $c f . S E G 33,717-729), 12$ inscriptions name eponymous magistrates of Knosos (1-12, ca. 110-75 BC). The nature of their activity in the sanctuary, in honour of Zeus Thenatas ( $c f .1:$ Tnvi Gevó $\tau \alpha l)$ is not stated, but since there is no indication of building activities which could have lasted more than twelve years, these texts cannot be building inscriptions; they probably commemorated the offering of an annual sacrifice. A dedication of a marble krater to Zeus Thenatas (13, late Hell.) and a lamp with the signature of Klaros $(14,2 \mathrm{nd} / 3 \mathrm{rd}$ cent. AD) were also found in this sanctuary. 
The inscriptions found in the 'cave of Eileithyia' at Amnisos include a fragmentary graffito on a vase (iعpóv) probably dedicated to Artemis (15, late Hell./ea. imp.), two lamps of the workshop of Eutyches (16a-b, imp.), and a loom weight inscribed with the letter E (17); loom weights are common dedications in Cretan sanctuaries. The cults of Amnisos (Eileithyia, Artemis, Zeus Thenatas) are discussed on the basis of the literary and epigaphic sources (p. 84-104). There is no evidence for a cult continuity in the sanctuary of Zeus Thenatas, from the Minoan period to the Geometric period, as suggested by the excavator of the site S. MARINATOS. Zeus' cult was probably established in Amnisos after the coming of the Dorians; his epitheton derives from a place name (Thene/ai), probably the name of a mountain. The cult, which flourished in the geometric and archaic period, reveals elements of syncretism of a Minoan fertility god and the Greek Zeus and may have been related to the mystery cult of Zeus Idaios. Its revival in the late Hellenistic period seems to be related to Knosos' efforts to defend its eastern boundaries from the expansion of Lyttos.

44) A. CHANIOTIS, Watcbing a lawsuit: A New Curse Tablet from Soutbern Russia, in GRBS, 33 (1992), p. 69-74 [BE 1993, 375]: The curse tablet EBGR 1987, 50 should be attributed to Olbia. In the context of a lawsuit, an unknown person cursed his opponents, their supporting speakers, and 'those who observe'. Several literary and epigaphic sources reveal the influence 'onlookers' (supporters on one of the parties) could have on the verdict of the jurors/judges.

45) A. CHANIOTIS - G. RETHEMIOTAKIS, Neue Inscbriften aus dem kaiserzeitlichen Lyttos, in Tycbe, 7 (1992), p. 27-38 [BE 1993, 400]: Ed. pr. of 5 honorific inscriptions on statue bases dedicated to emperor Hadrian (1-3) and his wife Sabina (4-5) from Lyttos (Crete). Three of these bases were found in situ in a room which may have been devoted to the emperor cult. A close study of the numerous statue bases for emperors (I.Cret. I,xviii 17-44), which were probably set up in the aforementioned room, shows that the statues were usually dedicated on the emperor's birthday. Sometimes the city dedicated pairs of statues, consisting of a statue of the emperor and a statue of a female member of his family (i.e., his wife or sister) [for annual dedications of imperial statues see also $S E G 41,1106$ ]. In the inscription which records the construction of the Serapeum in Gortyn (SIRIS 170) the name of the dedicant's son should be read as C. Petronius (not Metronius) Maximus (p. 38); the family of the Petronii Maximi may have been of Lyttian origin, since the name Petronius is attested only in Lyttos (I.Cret. I,xviil 140 and 141).

46) P. CHARNeuX, Sur un décret des forgerons d'Argos, in BCH, 116 (1992), p. 335343 [BE 1993, 261]: Ed. pr. of a document related to the association of the Argive smiths. After a statue ( $\alpha \dot{\alpha} \varphi(\sigma \mu \alpha$, an hapax) of Hephaistos had been stolen from the temple, a foreigner offered to fund the dedication of a new one (Argos, 1st cent. AD?).

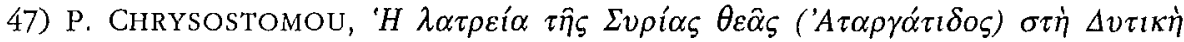

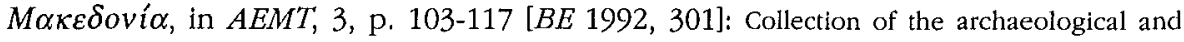

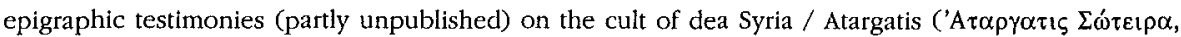

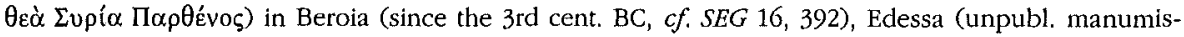
sion of the 2nd cent $\mathrm{AD}$ addressed to Thea Parthenos), Exoche Eordaias, Pella, Agios Nikolaos

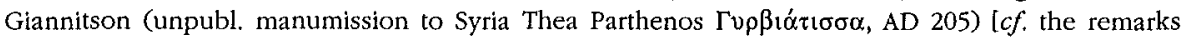
of M.B. HATZOPOULOS, in $B E$ 1992, 301 about the derivation of this epithet from an ethnic name; the popularity of the cult in the region of the Bryges and the manumission of slaves through dedication to this goddess indicate that her cult may have continued the local cult of a Mother Goddess]. C. also discusses the diffusion of Atargatis' cult in mainland Greece and the Aegean Islands since the Hell, age, and the importance of fish in her cult.

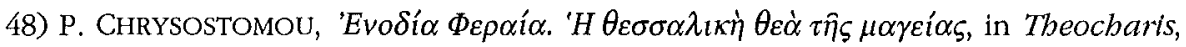
p. 532-533: C. presents a short summary of his research on the cult of Enodia, well attested archaeogically and epigraphically in Pherai (Thessaly) [cf. EBGR 1991, 43]. Unlike Athens, where Enodia was associated with Hekate and Persephone, in Thessaly her cult was always associated with those of Artemis, Zeus Meilichios, Zeus Thaulios, and Poseidon. The inscriptions attest a great variety of epithets (Astike, Polias, Hosia, Patroia, Korillos, Stathmia, Mykatia, Alexeatis). [ES] 
*49) M. Clauss, Cultores Mitbrae. Die Anbängerschaft des Mithras-Kultes, Stuttgart, 1992: C. collects 1003 inscriptions mentioning worshippers of Mithras, basically in the western provinces of the Roman Empire; the Greek East (including Moesia Inferior and Thrace) is rather weakly represented (p. 218-244). The study of this material shows that the cult originated in Italy; from Rome it spread out to the provinces. The rôle of soldiers and publicani for the cult's diffusion was substantial, but despite the strong presence of soldiers among the devotees of Mithras, this cult was widespread among the lower strata of society. Women were excluded from it. The majority of the worshippers was simply initiated into the cult, without proceeding to the initiation into the 'seven grades' [cf. SEG 40, 1720]. Mithras' cult flourished from the middle of the 2nd cent. AD; since the reign of Marcus Aurelius it was increasingly associated with the emperor and the emperor's cult. A revival can be noticed in the 4th cent. $A D$, esp. in aristocratic circles.

*50) S.G. COLE, Gunaiki ou themis: Gender Difference in the Greek Leges Sacrae, in Helios, 19 (1992), p. 104-122: C. gives an excellent overview of the regulations related to women in leges sacrae (restrictions and exclusions, purity requirements, priestesses). The regulations about the exclusion of women from cults are closely related to the exclusion of foreigners;

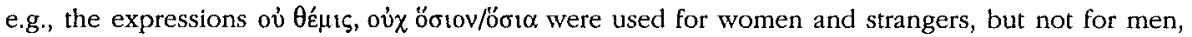
which implies that "the privileged group defined iself by exclusion of others". Women were usually excluded from cults of male gods (Herakles, Zeus Hypatos, Zeus Amalios, Zeus Apotropaios, Poseidon Phykios), especially of gods related to typical male activities [but for a priestess of Ares for lifetime see infra $\mathrm{n}^{\circ} 160 \mathrm{l}$. C. collects the evidece for purity requirements for worshippers and the various sources of pollution (birth, abortion, sexual intercourse, death). It seems that the popular tradition usually described the pollution as having a female source, gender neutral terms (e.g., ḋंò ovvovoías) being less common than terms which explicitly mention intercourse with a woman ('่) intercourse within and outside marriage. The treatment of male and female priesthoods by the Greeks reveals a 'gender assymetry'; male priests of female deities are more often attested than priestesses of male gods, priesthoods reserved for a certain clan were usually transmitted through male lineage, the prices for the purchase of a priesthood were higher for the offices of priests than those of priestesses, and the sexual requirements for priestesses were more stringent [on priestesses cf. infra ${ }^{\text {os }} 118,206$ ]. C. also discusses the rôle of women in mixed cults (esp. family cults), the various restrictions valid in women cults (restrictions of clothing, etc.), and the evidence for oaths of purity and marital fidelity. The regulations about women in the leges sacrae reflect the Greek system of social hierarchy based on distinction of gender.

51) Th. CORSTEN - Th. Drew-Bear, Sur deux inscriptions d'Eumeneia et d'Apameia en Pbrygie, in EA, 20 (1992), p. 135-142 [BE 1994, 566]: Reedition (with restorations) of the funerary inscriptions MAMA IV 388 A -B and IGR IV 803 which mention fines for violations of the graves,

52) F. Costabile (ed.), Polis ed Olympieion a Locri Epizepbyri. Costituzione, economia e finanze di una città della Magna Grecia, Catanzaro, 1992: The volume contains various contributions concerning the sanctuary of Zeus Olympios in Lokroi; notice the reedition of the Lokrian tablets (with translation) which concern loans made by the sanctuary to the city [cf. EBGR 1988, 118 and supra ${ }^{\circ}$ 3]. [ES]

53) L. Costamagna - C. SabBione, Una città in Magna Grecia: Locri Epizefiri, Reggio, 1992: Archaeological guide of Lokroi with extensive reference to the local sanctuaries and cults (Zeus Olympios, Persephone, Ares, Pan, the Nymphs, Aphrodite) in the light of the archaeological and epigraphic evidence. [ES]

54) J. COUPRY, Catalogue cbronologique par génération, dans leur existence mytbique, des dieux et béros belléniques à Marseille et dans les borizons massaliètes, in Marseille grecque, p. 155-160: Presentation of the cults attested in Massalia and the adjacent areas (esp. in Ligurian Olbia) and the respective myths (Mother deities, 
Aphrodite, Apollon Delphinios, Artemis Ephesia, Hera, Herakles, Leto, Poseidon Hippios, and Aristea). These cults find close parallels in cults of Ionia.

55) M.-L. CREMER, Hellenistisch-römische Grabstelen im nordwestlichen Kleinasien. 2. Bithynien (Asia Minor Studien, 4.2), Bonn, 1992 [BE 1993, 557; 1994, 27]: The second part of this study of the grave stelae in Northwest Asia Minor (Hell., imp. times) [cf. EBGR 1991, 53] presents the material from Bithynia (Nikomedeia, Nikaia, Preietos, Pylai, Otroia, Prusa ad Olympum, Herakleia Pontike, Bithynion, and Klaudioupolis). C. focuses on the iconography of the grave stelae. Their predominant motif is the funerary banquet; the focal point in the Bithynian stelae is the man, usually holding a crown in his hand. Prothesis scenes are also popular in this region. The catalogue (p. 119-180) provides a representative collection of grave inscriptions with banal formulas, including several unpublished texts. Fines for the violation of graves, payable to the city or the fiscus, are mentioned in a few texts (NK 10,11, Y 9, 10). One monument has a funerary

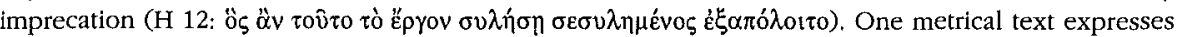
thoughts about the unavoidability of death (Tarpak 1) [cf. SEG 41, 1873]. The catalogue includes

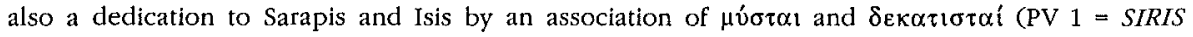
326).

56) B. CROWTHER, Second-Place Finishes and Lower in Greek Atbletics (Including the Pentatblon), in ZPE, 90 (1992), p. 97-102 [BE 1993, 249]: A review of the literary and epigraphic evidence shows that in some athletic contests, e.g., in Eleusis (IG $\mathrm{I}^{2} 846$ ), in the Panathenaia (IG $\mathrm{II}^{2}$ 2311), in the Koan Asklepieia and Koresia (Sy/l. ${ }^{3}$ 958), and in an agon in Aphrodisias ( $C I G$ 2758), places other than the first were recorded; sometimes second-place victors received an award.

57) G. DAREgGI, Dedica ad Hera su di un frammento ceramico a figure nere nel museo di Baranello, in Eumusia, p. 173-178: Ed. pr. of a sherd of a blackfigure vase (late 6th cent. $\mathrm{BC}$ ) with the representation of an ithyphallic Silen and a mule; a graffito shows that the vase was dedicated to Hera ( $\tau \tilde{\varepsilon} \zeta$ Hépe[ $\zeta]$ ). The provenance could be Kyme (Italy), where a similar inscription was found in 1860 .

58) F. DE ANGELIS, A forgotten inscription from Khlembotsári (Asopía), Boiotia, in Boeotia Antiqua, 2, p. 53-55: D. restores the name of the deceased in a gravestone mentioned by the traveler H.N. ULRICHS (Reisen und Forschungen in Griechenland II. Topographische und arcbäologische Abhandlungen, Berlin,1863, p. 81) as Xóponos, a theophoric name related to the cult of Herakles Charops in Thespiai. [ES]

59) M. Debrunner Hall, The Reluctant Rbetor: A Recently Published Inscription from Late Imperial Ephesos, in ZPE, 91 (1992), p. 121-128 [SEG 39, 1193]: D. argues that the epideictic oration, whose end is preserved on a recently published inscription of Ephesos (SEG

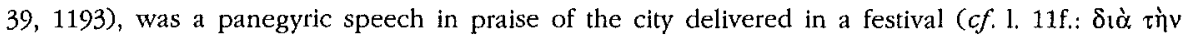

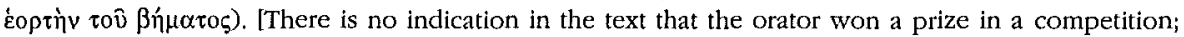

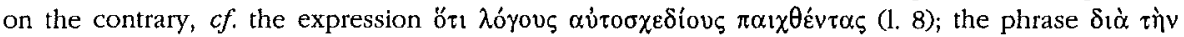

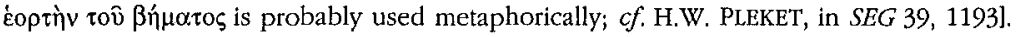

60) C. DE FILIPPIS CAPPAI, Il culto di Asclepio da Epidauro a Roma. Medicina del tempio e medicina scientifica, in Civiltà Classica e Cristiana, 12 (1991), p. 271-284: Overview of the history of Asklepios' cult in the insula Tiberina in Rome with reference to the healing miracles [but with no knowledge of the recent bibliography and citation of the antiquated edition of the healing miracles in CIG 5980; see now IGUR I, 148; for the Roman Asklepieion see now infra $\left.^{\circ} 85\right]$.

61) S. DE VIDO, Segesta: Fonti epigrafiche, in ASNP, 21 (1991), p. 971-980 [BE 1993, 718; $S E G$ 41, 824]: Collection of the inscriptions of Segesta (no new texts, no commentaries). They include a dedication to Aphrodite Ourania ( $I G$ XIV 287, of the statue of her priestess). The text mentions the sacred officials of the city (hierothytes, hieromnemon, hierophylakes). 
62) J. DeVReKer, Nouveaux monuments et inscriptions de Pessinonte et d'ailleurs, in $E A, 20$ (1992), p. 25-31 [ $B E 1993,580]$ : Ed. pr. of a fragmentary imperial letter (Tekören, territory of Pessinous, 1st/2nd cent.). An anonymous emperor permits an individual to dedicated

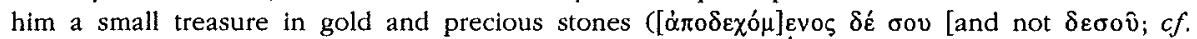

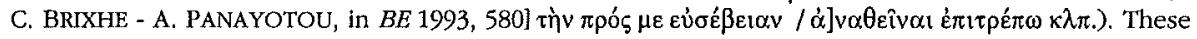
objects were probably deposited in the local Sebasteion.

63) L. DuBoIs, Deux noms mythiques, in RPh, 65 (1991), p. 99-104 [SEG 41, 1709, 1789]: Linguistic study of the names of two satyrs, which appear on Chalcidic vases of the 6th cent.

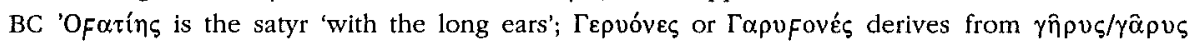
('voice')", i.e., he is the satyr 'with the loud voice'.

64) H. DUCHÊNE, La stèle du port. Fouilles du port 1. Recherches sur une nouvelle inscription thasienne (Études Thasiennes, XV), Paris, 1992 [BE 1993, 395]: Ed. pr. of a Thasian law with regulations aiming at keeping the streets clean and orderly (ca. 470/60). [Cf. the review by A. MARTIN, in $A C, 63,1994$, p. 495f.]. D. offers a very detailed commentary of the regulations, the topography, and the cults. The basic religious interest of the text consists in the mention of the sanctuaries of Herakles and the Charites as points of orientation. One of the streets is called 'the street of the sanctuary of the Charites' (1. 3), i.e., it was used for processions. The fines for violations were paid partly to the city and partly to Apollon Pythios (1. 7-10). The law prohibited the throwing of excrements on the street leading from the sanctuary of the Charites to the Prytaneion; fines for violations of this regulation were to be paid to the city, but if the epistatai neglected to collect the fine, they should pay themselves the duplum to Artemis Hekate (1. 48f). In order to establish the chronology of the text $\mathrm{D}$. republishes all the archaic and early classical inscriptions of Thasos (p. 110-128, ca. 550-430 BC).

65) H. ENGELMANN - A.B. ÜNER, Inschriften aus dem Museum von Karaman (Lycaonia), in Anzeiger Wien, 129 (1992), p. 1-24: Ed. pr. of inscriptions from various places in Lykaonia, including two dedicatory inscriptions to Theoi patrioi (1, Derbe, on a pillar) and Zeus (2, on an altar), and two funerary imprecations addressed to Mes Ouranios and Menes

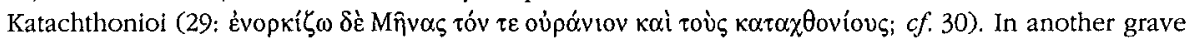
inscription, written on the statue of a lion, the deceased is presented ordering the burial of his

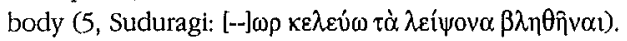

66) S. ENSOLI VITOZZI, Indagini sul culto di Iside a Cirene, in Africa romana, 9, p. 167-250 [BE 1993, 699]: Thorough study of the cult of Isis at Kyrene on the basis of archaeological, literary, and epigraphic sources (5th cent. BC - 5th cent. AD). A local (Libyan-Egyptian) deity was associated by the Greek colonists with Demeter and Kore, Tyche, and Ge; the agricultural and chthonic elements were predominant in her cult. Initiation rituals became part of this cult already in the classical period, i.e., earlier than in other parts of the Graeco-Roman world, probably under the influence of Demeter's cult. [ES]

*67) C.A. FARAONE, Talismans and Trojan Horses: Guardian Statues in Ancient Greek Myth and Ritual, New York-Oxford, 1992: F. collects and discusses an impressive amount of literary, epigraphic, and papyrological testimonia for the manufacture, use, and special treatment of statues and other forms of effigies as a means for averting evil (erection of statues of dogs and lions at the entrances of cities and monumental buildings, erection of effigies of bowbearing plague gods at the gates of cities, burying and binding the images of evil forces). These practices are close parallels to rituals described in the early Near Eastern sources. F. argues convincingly that the scanty evidence for the use of talismanic images in the classical period is a result of the uneavenness of our sources, and does not indicate a discontinuity in the performance of these apotropaic rituals. I focus here on a few epigraphic aspects of F.'s study. F. suggests that the yó $\lambda \lambda$ or mentioned in the lex sacra of the Milesian molpoi (LSAM 50), i.e., stones set up near the statue of Hekate Propylaia and the gates of Didyma, may have performed some protective function (p. 6) [for the apotropaic use of stones and baetyls cf. infra ${ }^{\circ} 121$ and $E B G R$ 1991, 116]. He collects and discusses the literary and epigraphic evidence (esp. oracles of Apollon Klarios) for the 
erection of statues of Apollon during the great plague of AD 165/66 (p. 61-64) [cf. now the new oracle (for Sardis?), infra $\mathrm{n}^{\circ}$ 84]. The binding of a statue of Ares, which an oracle of Apollon Klarios recommended to the city of Syedra, finds close parallels in apotropaic practices mentioned in the mythological and literary tradition (p. 74-78) [cf. $E B G R$ 1991, 68]. F. interprets the

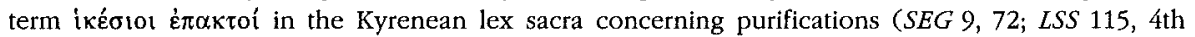
cent.) as 'visitants' or 'evil spirits', and sees in the ritual described in this text a 'ghost-banning ritual' (p. 81f.) [for the same view, with reference to a new text from Selinous, $c f$. M.H. JAMESON D.R. JORDAN - R.D. KOTANSKY, A Lex Sacra from Selinous (GRBS Monographs, 11), Durham, 1993,

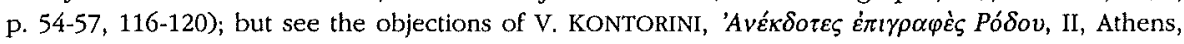
1989 , p. 17-29 (EBGR 1989, 60)], Also notice a collection of testimonia for gods regarded as $\pi \rho 0 \pi u ́ \lambda \alpha$ ol (p. 7-9) [for Herakles $c f . E B G R$ 1991, 157; for Apollon see infra $\mathrm{n}^{\circ}$ 178] and brief

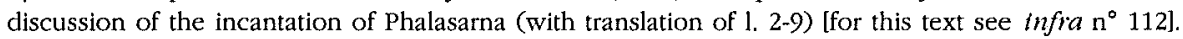

68) C.A. FARAONE, Sex and Power: Male-Targetting Apbrodisiacs in tbe Greek Magical Tradition, in Helios, 19 (1992), p. 92-103: F. presents some evidence (basically literary and papyrological, but also one amulet) that support the view that the erotic magical rituals aimed at attracting men were different than those aimed at attracting women. The male-targeting spells were primarily concerned with enervating and controlling the 'normally' active men, whereas the female-targeting spells aimed at energizing the 'naturally' passive female. This association of effeminacy and sexual excitement reflects the Greek attitude that linked male sexual identity with the ability to control one's sexual desire. It sould be noticed that the male-targeting magic appears often in contexts which involve the usurpation of male power. Consequently, this magic, which weakened self-control, could be associated with political magic.

69) C.A. FARAONE, Aristophanes, Amphiaraus, fr. 29 (Kassel-Austin): Oracular Response or Erotic Incantation?, $C Q, 42$ (1992), p. 320-327: The hexametrical verses

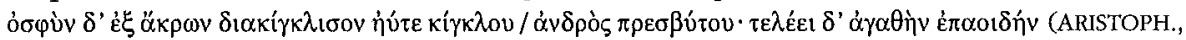
fr. $29 \mathrm{~K}-\mathrm{A})$ are not an oracular response which proscribes how the petitioner might increase the sexual ardour of an old man, but an erotic incantation. Both the formulaic expression $\tau \varepsilon \lambda \varepsilon i ̂ v$ $\varepsilon \dot{\varepsilon} \alpha 01 \delta \eta \dot{v} v$ and the content of the verses (Aphrodite's 'attack' on a specific body part, allusion to the

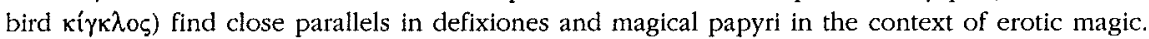

70) Th. FISCHER, Tryphons verfeblter Sieg von Dor?, in, ZPE, 93 (1992), p. 29-30 [BE 1993, 117]: F. restores the inscription on a lead sling-bullet from Dor (Palestine, SEG 32, 1500; 35,

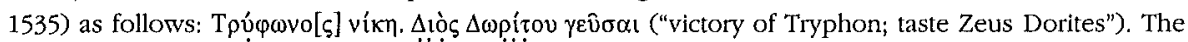
text was written by followers of the usurper Tryphon $(138 \mathrm{BC})$ in Dor during the siege of the city by the troops of Antiochos VIII.

71) S. FOLLET, Hadrien ktistès kai oikistès: lexicographie et realia, in F. LÉTOUBLON (ed.), La langue et les textes en grec ancien. Actes du colloque Pierre Chantraine (Grenoble 5-8 septembre 1989), Amsterdam, 1992, p. 241-254: In an honorific inscrip-

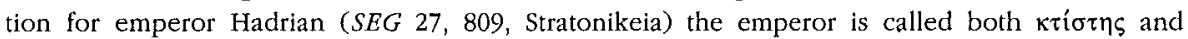

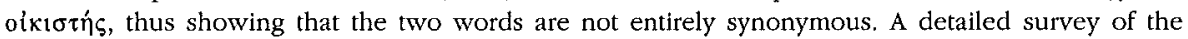
semantic field of these words, esp. when used to designate benefactors, heroes (founders of cities), and emperors, implies that the word xriotns underlines the material procedure of the foundation of the city ("bâtisseur"), whereas oikıðтn's underlines the settlement of population ("colonisateur").

72) J.M. FossEy, A Dedication from Thisbe, Wrongly Assigned to Kborsiai, in Boeotia Antiqua, 2, p. 47-51 [BE 1993, 63]: Reedition of a dedication to Artemis Soteira (SEG 36,420 , ea. 2nd cent. BC ), which should be assigned to Thisbe, not to the Chorsiai. The cult of Artemis Soteira was already attested for Thisbe (Hell., imp.); the goddess was probably worshipped only in the two larger cities of southwest Boiotia (Thespiai and Thisbe), but was also diffused in the neighbouring areas to the South-East and in Megaris. [ES] 
73) D. FrENCH, Sinopean Notes 3, in EA, 19 (1992), p. 45-59: Ed. pr. of inscriptions from Sinope. A grave inscription ( 3 , imp.) mentions a fine payable to the city for violations of the grave

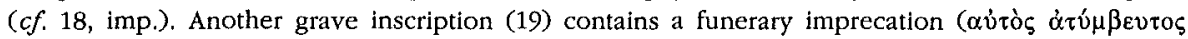

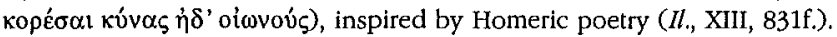

74) D. FRENCH, Amasian Notes 2, in EA, 20 (1992), p. 63-68 [BE 1994, 577, 579-581]: Ed. pr. of the gravestone of Helonios (Amaseia, AD 252/3) which attests the month-name Neronios, previously unrecorded in the Amaseian calendar. The other four month-names attested in Amaseia are also related to Augustus' family: Sebastos, Agrippeos, Oktavios, Aphrodiseos (-eos for -aios). The next parallels of these month-names can be found in the Cypriote calendar introduced in $15 \mathrm{BC}$ (Sebastos, Agrippaios, Livaios, Oktavios, Ioulaios?, Neronaios, Drusaios, Aphrodisaios, Anchisaios, Rhomaios, Aineadaios, Kapetolios). These observations permit the restoration of the month-name

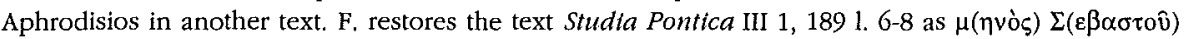

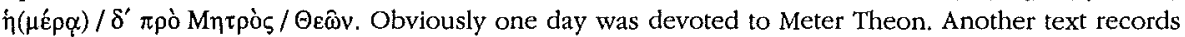

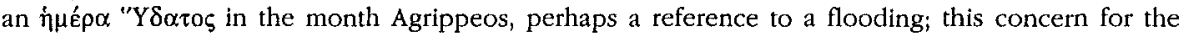

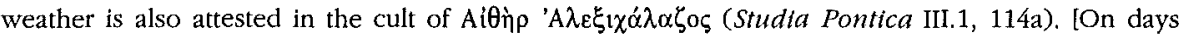
named after a deity, a festival, or a cult see, e.g., supra $\mathrm{n}^{\circ} 12$ : 'the day of Apollon' (40)].

75) S.S. FRERE - R.S.O. TOMLIN, The Roman Inscriptions of Britain. Volume II. Instrumentum Dometicum. Fascicule 4, Stroud, 1992: The corpus of the inscriptions on instrumentum domesticum found in Britain contains a few Greek texts of religious importance. The words $\theta \varepsilon[\hat{\varphi}]$ or $\theta \varepsilon[o \hat{\zeta}]$ and [i $\varepsilon]$ póv may be restored on fragments of a wallplaster (2447.18 b, c, Tripontium). Also notice the inscription MATRI (Marti) on a small circular object of mudstone with the respresentation of a figure wearing a wreath and armed with shield and sword, obviously Mars (2453.3, Newtown, Powys). The dedicant of the mosaic inscription in the temple of Nodens (2448.3 = CIL VII 137 add. p. 314, Lydney Park) T. Flavius Senilis may have had the title pr(aepositus religionis) (not (rel(iquationis) as suggested by TH. MOMMSEN); he was assisted by the dream interpreter Victorinus. The mosaic of the Nine Muses in a private house at Isurium preserves the Greek inscription 'E $\lambda \eta \times \omega ́ v$ (2448.5 = IG XIV 2549).

*76) J.G. GAGER, Curse Tablets and Binding Spells from the Ancient World, New York-Oxford, 1992 [BE 1993, 104]: Collection of 168 translations of curse tablets and spells, preserved on Greek and Latin inscriptions from the entire Mediterranean and in Graeco-Roman papyri, with brief commentaries, rich illustration, a glossary, and a very informative introduction on Greek and Roman defixiones (materials used, types of messages, gods invoked in spells and curses, use of 'voodoo dolls', depositing of curse tablets, Near Eastern and Egyptian parallels). The collection includes curses concerning competition in theater and circus, love, political and legal disputes, economic conflicts, appeals to justice [cf. EBGR 1991, 261], antidotes, and counterspells.

77) M. GARCIA TEIJEIRo, Langage orgiastique et glossolalie, in Kernos, 5 (1992), p. 59-69: Study of the use of 'pseudo-words' and crys in the context of orgiastic and mystery cults, divination, and magic, with reference to literary sources, magical papyri, and inscriptions (e.g., an

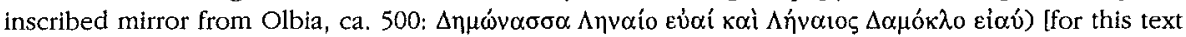
see H.S. VERSNEL, infra $\mathrm{n}^{\circ} 234$ p. 140]. With regard to the use of a jargon by secret associations $\mathrm{G}$. refers to the inscribed kantharos from the Theban Kabeireion (5th cent.) with representations of Mitos, Krateia, and Protolaos, pointing out the association between weaving and procreation ffor Orphic elements in this representation see most recently EBGR 1991, 168].

78) DJ. Gargola, Grain Distribution and the Revenue of the Temple of Hera on Samos, in Pboenix, 46 (1992), p. 12-28 [BE 1993, 392]: G. argues that the Samian law concerning free grain distribution to the citizens ( $S y l l .^{3} 967,3 \mathrm{rd} / 2$ nd cent.) did not aim at preserving the standard of living of citizens, but at simplifying the financial administration of the Heraion. This view is based on a series of observations: The Samian grain fund concerned only grain from the Samian territory, and thus it could not ameliorate a grain shortage in Samos itself. The law neither maximized the amount of grain available nor did it establish a fixed price. The interest from the estimated amount of the fund (ca. 50,000 drachmas) couldn't have provided more 
than 5,000 drachmas annually for the purchase of grain (less than 1,000 medimnoi); consequently, the monthly ration of two metra (cboinikes rather than medimnol) distributed to the citizens would have provided subsistence for no more than 2 days. Consequently, the law could have never provided a significant amount of grain for the population. G. finds a clue for the interpretation of the text in the provision that grain was to be bought primarily from the grain delivered to Hera as tithe for the cultivation of the region Anaia (5\% of the produce) [for this practice cf. supra $\mathrm{n}^{\circ} 3$ ]. Only after the grain of the goddess had been bought could the remaining money be used for secondary purchase of grain. With this system the revente paid to Hera in kind (in grain) could be converted into money. Precaution was taken to establish a price not lower than $5 \mathrm{dr}$ and 2 obols. [This ingenious interpretation remains too hypothetical, given the fragmentary preservation of the text and the fact that we know neither the size of the population of Samos nor if the grain was distributed to all the citizens. The recipients could have been defined in a lost portion of the text. Furthermore, the estimation of the amount of the fund is hypothetical, as is the identification of the metron with the choinix, and not with the medimnos. See also the remarks of Ph. GAUTHIER, in $B E$ 1993, 392].

*79) R. GARLAND, Introducing New Gods: The Politics of Athenian Religion, Ithaca, 1992: G. studies the introduction of new cults in Athens in the 5 th cent. BC, i.e., between the Persian Wars and Sokrates' trial. In this period, the cult of Pan was introduced from Arkadia after the battle at Marathon, Themistokles established the cult of Artemis Aristoboule after the victory at Salamis, Theseus' cult was supported by Kimon, the cults of Bendis and Asklepios were introduced

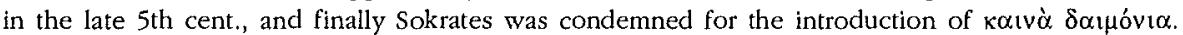
[For the significance of Theseus for the Athenian collective memory and identity, see C. CALAME, Thésée et l'imaginatre atbénten, Lausanne, 1990, not used by G. For a critical appraisal of recent works on Theseus and his worship in Athens see D. VIVIERs, Thésée l'Atbénien. $\grave{A}$ propos de quelques ouvrages récents, in $A C, 62$ (1993), p. 239-245; for the cult of Bendis in Athens see C. MONTEPAONE, Bendis tracia ad Atene: L'integrazione del "nuovo" attraverso forme dell'ideologia, in Mélanges Lévêque, 6, p. 201-219; infra $\mathrm{n}^{\circ}$ 234]. G. focuses on the political background of the introduction of these cults (thanksgiving for victories, contribution to national feelings, imperialistic propaganda), demonstrating the increasing interference of the demos in the regulation of religious matters. G. argues that because of the people's authority to approve the entry of new cults, persons introducing new cults without official approval were liable to prosecution; he also claims that the arrival of new gods in Athens often had a profound impact upon their status throughout the Greek world (Pan, Asklepios). [For the shaky evidence for the last two claims see B. JORDAN's review, in $A J P b, 115$ (1994), p. 132]. I focus here only on a few aspects of the book, for which G. exploits the epigraphic evidence. a) G. suggests that the reorganization of the Herakleia of Marathon ( $I G \mathrm{I}^{3} 3=\operatorname{SEG}$ XXXIV 1, ea. 5th cent.) may have been decreed shortly after the battle of Marathon in acknowledgement of Herakles' contribution to the Athenian victory (p. 57). In the same period the cult of Nemesis in Rhamnous, to the north of Marathon, reminded the Athenians of the Persian hybris. b) $G$, interprets the Athenian decree concerning the Praxiergidai and their duties in the festivals Plynteria and Kallynteria $\left(I G \mathrm{I}^{3} 7\right)$ as an early example of the people's rising power in religious matters; he suggests that the decree was passed in order to resolve a dispute between the demos and the Praxiergidai concerning the latter's prerogatives (p. 100-102). A further example of public intervention in the running of a possibly gentilician cult is the decree which opened the priesthood of Athena Nike to all Athenian women ( $I G \mathrm{I}^{3} 35, \mathrm{c} .448, \mathrm{p} .102 \mathrm{f}$.). c) The examples which demonstrate how Athenian cults served the foreign policy of imperialist Athen (p. 106-109) include the decree concerning the conribution of Erythrai to the Panathenaia (IG $\mathrm{I}^{3}$

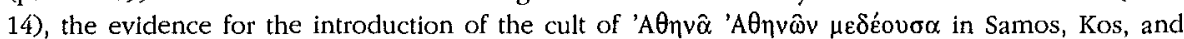
Chalkis, and the decree regulating the offering of first-fruits to Eleusis (IG $\mathrm{I}^{3} 78$ ), d) $\mathrm{G}$. discusses the introduction of the cult of Asklepios in Athens $(420 \mathrm{BC})$ against the background of the plague which afflicted Athens in the first years of the Peloponnesian War; he underlines its connection to the cult of the Eleusinian goddesses and its gradual transformation to a public cult. [The discussion of Asklepios' cult is characterized by several mistakes and a very limited use of the most recent bibliography. G. ignores the books of G. SOLIMANO, Asclepio, le aree del mito, Genova, 1976 and 
A. KRUG, Heilkunst und Heilkult, Munich, 1985. As regards the probable origin of Asklepios' cult in Thessaly (p. 116-118) see, e.g., A. SEMERIA, Per un consimento degli Askleptela della Grecia continentale et delle isole, in ASNP, 16 (1986), p. 931-958; C. BENEDUM, Asklepios - Der bomerische Arzt und der Gott von Epidauros, in RbM, 133 (1990), p. 210-226; on the introduction of the cult in Athens, ibid. p. 222-224. On the question of Apollon Maleatas in Epidauros (p. 117), G. does not take into consideration the recent reserarch in the Asklepieion and the sanctuary of Apollon Maleatas (see, the annual reports of V. LAMPRINOUDAKIS, in PAAH). The assertion that "only at Epidauros did grateful patients set up lengthy inscriptions recording their cure in minute detail" is wrong; similar practices are attested from the Asklepieia at Lebena (I.Cret. I,xvii 8, 17-19), Kos, and Trikka (STRAB., VIII, 6, 15; XIV, 2, 19). G. speculates on "the possible existence of an extensive network of sanctuaries dedicated to the god and his entourage throughout Attica" (p. 133), with no reference to the evidence for Asklepios' sanctuaries in Acharnai, Prospaltai (A. MLCHHÖFER, in MDAI (A), 13, 1888, p. 284, 339; F. KUTSCH, Attische Götter und Heilheroen, Giessen 1913, p. 118), Sounion ( $I G \mathrm{II}^{2} 1181$, late 4th cent.), and Pentele (SEG 28, 229). Asklepios' cult was not the only cult of a healing deity introduced to Athens after the great plague; see LOUKIAN., Skythes 1-2, for the cult of Toxaris. On the relation of Asklepios to Demeter see C. BENEDUM, Asklepios und Demeter. Zur Bedeutung weiblicher Gotthetten fitr den friben Asklepioskult, in JdI, 101 (1986), p. 137f. For Telemachos' monument see A. CHANIOTIS, Historle und Historiker in den griechiscben Inschriften, Stuttgart, 1988, p. 220-222. For recent work on the Athenian Asklepieion see supra $\mathrm{n}^{\circ} 1$ and $E B G R$ 1989, 3; 1991, 2, 3. The sanctuaries of Asklepios are discussed in the (unpublished) dissertation of J. RIETHMÜLLER, Asklepieia. Heiligtiumer und Kulte elner griechischen Heilgottheit, Heidelberg, 1994, which I was able to consult for this review]. In the case of Sokrates' trial, G. convincingly argues that Sokrates' philosophical and religious views were equally responsible for his conviction as his political attitudes [for charges of asebeia in Athens see H.S. VERSNEL, infra $n^{\circ} 234$, p. 123-131). In a few instances $G$. considers epigraphic parallels outside Attika, e.g., on epiphanies of gods which lead to the introduction of their cult (Sarapis in Delos and Opous: IG XI 4, 1299; IG X.2.1, 255) and on the consultation of oracles (p. 14-22).

80) T. GESZTELYI, Zur Deutung der sogenannten Grylloi, in Acta Classica Universitatis Sctentiarum Debreceniensis, 28 (1992), p. 83-90: G. discusses the 'mask-animal gems', i.e., gems with respresentations of various body parts combined with silen masks ('grylloi'). A close

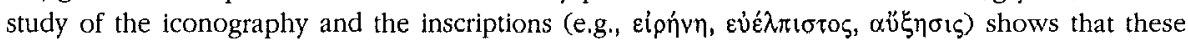
gems fulfilled a variety of functions (apotropaic, benedictory, love-magic). G. finds close parallels between the representations and the contemporary love poetry (esp. with regard to the symbolic significance of animals). The representations did not aim at depicting a specific daemon, but rather combined a variety of components according to the specific symbolism intended by their purchaser.

81) F. GHINATTI, Dedica votiva siceliota, in Sileno, 18 (1992), p. 67-74: Ed. pr. of a lead tablet from Palma di Montechiaro (territory of Akragas, ea. 3rd cent. BC) with a dedicatory inscrip-

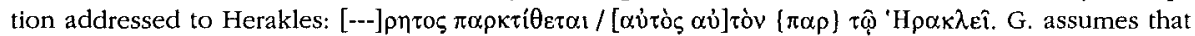
the dedicant dedicated his image in a sanctuary of Herakles, whose cult is attested in this area. The verb $\pi \alpha \rho \alpha \kappa \alpha \tau i \theta \varepsilon \mu \alpha \mathrm{l}$ is used in the similar texts from Herakleia (SEG 30, 1163-1164) for their interpretation see infra $\left.{ }^{\circ} 199\right]$.

82) P. GHiron-Bistagne, Un autel massaliote de Zeus Patrôos, in Marseille grecque, p. 151-154: Ed. pr. of an altar dedicated to Zeus Patroos by a cult association (Massalia,

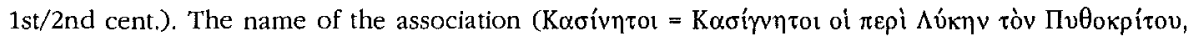
'the brothers together with Lykes, the son of Pythokritos) indicates that its members claimed common descent.

83) Z. GoČEVA, Le culte d'Apollon, in DHA, 18 (1992), p. 163-171: G, argues that Apollon's cult was introduced in Thrace approximately in the same period as it was introduced in mainland Greece. However, in Thrace his worship was influenced by local factors, and the god was associated with local deities, e.g., Derainos in Abdera, Kendreisos in Philippoupolis, and the local 
Thracian hero. Apollon's epithet Aularkenos probably characterizes the god as protector of the household. [ES]

84) F, GRAF, An Oracle Against Pestilence from a Western Anatolian Town, in ZPE, 92 (1992), p. 267-279 [ $B E$ 1993, 49; $S E G$ 41, 981]: G. republishes the metrical oracle of Apollon found in Ephesos (SEG 41, 981; $E B G R$ 1991, 160). I give G.'s translation: “[... For Help, you have to look tol Artemis with the golden quiver, born from my family; for she is the ancestral leader of the entire town from its origin, midwife and augmenter of mortals, giver of harvest. Her form bring in from Ephesus, brilliant with gold. Put her up in a temple, full of joy; she will provide deliverance from your affliction and will dissolve the poison (or: magic) of pestilence, which destroys men, and will melt down with her flame-bearing torches in nightly fire the kneaded works of wax, the signs of the evil art of a sorcerer. But when you have performed for the goddess my decrees, worship with hymns the shooter of arrows, the irresistible, straight shooting one, and with sacrifices, her, the renowned and vigilant virgin; and during dancing and feasting, you girls together with the boys, above the salty lands of Maeonic Hermus, praising her in every respect wear crowns of large myrtle, having called from the Ephesian land the pure Artemis, in order that she might always be to you an unfailing helper. If you should not fulfill the rites, then you will pay the penalty of fire". The god, after describing the properties of his sister as protector of birth and fertility, prescribes the actual course of action. A statue of the goddess (probably bearing two torches, as depicted on coins of Ephesos) was to be brought to the town from Ephesos in order to avert the plague. Then the city should perform a thanksgiving ritual (probably in the sanctuary of Artemis Koloene). G. identifies the plague with the one of AD $165 / 6$, the petitioner with Sardis, and the oracle with that of Klaros, which is known to have advised the aversion of plague through the erection of statues [cf. $\ln f r a \mathrm{n}^{\circ}$ 67]. The two torches show that the goddess was worshipped as Artemis Soteira or Phosphoros, who was often regarded as averter of evil. The golden statue recalls the use of fire for averting evil. This is an isolated example for the use of fire to undo black magic by the Greeks: Artemis' torches were supposed to burn the waxen figurines ('voodoo-dolls'), with which an evil sorcerer $\left(\mu \alpha \gamma_{0}\right)$ was believed to have caused the plague. The text offers an interesting example for the aversion of a crisis caused by magic through recourse to divine help.

*85) F. GRAF, Heiligtum und Ritual. Das Beispiel der griechisch-römiscben Asklepieia, in Le sanctuaire grec, p. 159-199: Thorough discussion of the common features of Asklepios' sanctuaries with ample use of the epigraphic evidence. G. focuses on the Asklepieia of Epidauros and Rome, on the usually liminal locations of Asklepieia (outside urban centers, in the vicinity of water sources and groves), on the incubation and the related rituals.

86) A.J. Graham, Abdera and Teos, in JHS, 112 (1992), p. 44-73 [BE 1993, 453; SEG 41, 1001]: $G$. discusses the political implications of those passages of the Tean imprecations (SEG 31 , 985) [cf. infra $\mathrm{n}^{\circ}$ 197] which refer to Abdera. The fact that Teos legislated for Abdera implies some merging of the political identities of the two cities.

87) W. GÜNTHER, Athenisches Biirgerrecht für Theoren aus Milet, in EA, 19 (1992), p. 135-143 [BE 1993, 482]: Ed. pr. of an Athenian honorific decree for Milesian theoroi (Miletos, ca. 180/160). The sacred embassy of Miletos to Athens consisted of five theoroi and the architheoros Hermophantos, the son of the prominent politician Lichas. Hermophantos was already known as member of another Milesian theoria to Athens [EBGR 1991, 93]. The Milesian theoroi were honoured with crowns, citizenship, and anouncement of these honours in the festivals of the Dionysia in Athens and in Miletos. G. collects the epigraphic evidence for the Milesian Dionysia and comments on the religious relations between Athens and Miletos (cult of Athena, kinship, sending of theoriai).

88) Ch. HABICHT, Athens and the Ptolemies, in ClAnt, 11 (1992), p. 68-90 [BE 1993, 237]: In an overview of the relations between Athens and the Ptolemies, H. discusses briefly the nature and date of the Ptolemaia in Alexandria (p. $70 \mathrm{n}$. 10), esp. in view of the information included in the honorific decree for Kallias (SEG 28, 60). He suggests that the Ptolemaia were originally a one-time celebration, part of the funeral ceremonies for Ptolemy I (282 BC); Ptolemy II 
transformed them into a pentaeteric festival in 280 or $279 \mathrm{BC}$. The revival of the Panathenaia should be dated in $282 \mathrm{BC}$. H. also presents the evidence for the participation of members of the house of the Ptolemies in the Panathenaia (in horse and chariot races) in the 2nd cent. (p. 78).

89) H. HARRAuer, Soubrom, Abrasax, Jabwe u.a. aus Syrien, in Tyche, 7 (1992), p. 3944 [BE 1993, 107]: 1) Ed. pr. of a magical gem from Syria. The inscription $\Sigma$ OYB POM-

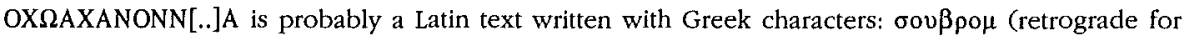
$\mu \circ \rho \beta o v \sigma$, i.e., morbus), (b)oc o (b)ac a non nlocela(t) or non nloxja; an alternative reading of the last words is $0 \chi \omega \alpha \chi$ (magical words) $\alpha$ vóv $(v)[\eta \tau] \alpha$ ('ineffectual'). The text is arranged in such a way that the letters $A$ and $\Omega$ occupy the central position. 2) Ed. pr. of a gem with the texts $A \beta \rho \alpha \sigma \alpha \xi{ }_{1} \alpha \omega$

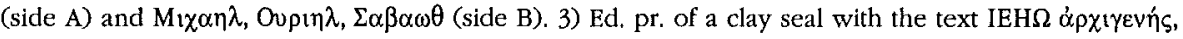

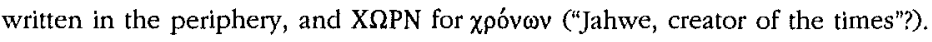

90) D. HARRIS, Bronze Statues on the Athenian Acropolis. The Evidence of a Lycourgan Inventory, in AJA, 96 (1992), p. 637-652 [BE 1993, 89]: H. argues that the inventory $I G \mathrm{II}^{2} 1498-1501 \mathrm{~A}$, a list of bronze statues, was a catalogue of dedications removed from the Akropolis in order to be melted and recast into new cult equipment under the responsibility of the treasurers of Athena. [Not all the objects listed in this inventory were necessarily made of bronze. H. assumes that the stelai mentioned in $I G \mathrm{II}^{2} 1498 \mathrm{~A}$ col. I 1. 6, 8-10 were made of bronze (p. 639); but since their material is not specified, we should rather expect common stone stelai. Since the

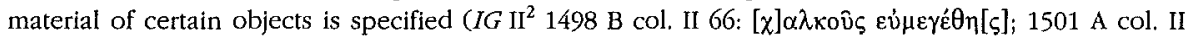
13: tò $\chi \alpha \lambda \kappa o[\hat{v} v]$, shouldn't we assume that not all the object were made of the same material? Otherwise the differentiation makes no sense]. As can be inferred from the detailed description of the statues, many of them were damaged. The list may be part of the measures taken on the initiative of Lykurgos for the reorganization of the Akropolis in the $330 \mathrm{~s} \mathrm{BC}$. The inventory mentions a large number of statues of children holding animals and objects; this kind of dedication is unknown from the archaic Akropolis, but seems to have been common in the 4th cent.; these statues may have stood in the shrine of Artemis Brauronia. [If this was the case, why doesn't the inventory mention any statues of girls?]. The statues were probably full-size, Except for statues of children, the inventory mentions three Palladia and statues of nude or dressed, bearded men. The prosopography of the dedicants shows that they belonged to various social strata. H. gives a very conservative edition and translation of the inventory. [Since several standard formulas are used in this inventory, substantially more restorations are possible; e.g., the standard expression $\dot{\alpha} \pi 0 \sigma \tau \alpha \tau \varepsilon \hat{\imath}$ ö, $\tau 1$

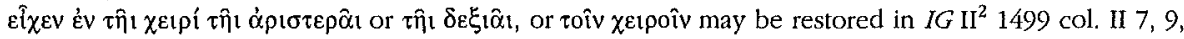
10; $1500 \mathrm{~A}$ col. I 9f., col. II 19; $1498 \mathrm{~B}$ col. II 47, 62, 68, 70,72f.?, 76?, 79; 1500 B col. I 33f., 35f., 37f.;

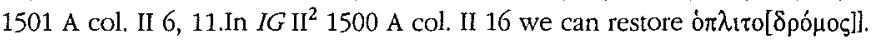

91) W.V. HARRIS, An Inscription Recording a Proconsul's Visit to Samothrace in 165 $A D$, in $A J P h, 113$ (1992), p. 71-79: H. reedits an inscription found in Samothrake (BE 1966, 342) which records the visit of the proconsul of Macedonia P. Anteius Orestes, six of his friends, and several slaves, who were probably initiated in the local mysteries. The text dates from May 1st, AD 165 (May = Mounychion in the local calendar).

92) M.B. HATZOPOUlos - L.D. LouKopoulou, Recherches sur les marches orientales des Téménides (Antbémonte - Kalindoia). 1ère Partie, Athens, 1992 [SEG 40, 542; BE 1993, 365]: Corpus of the inscriptions of Anthemous and Kallindoia (Chalkidike). M.-L. discuss in detail the Macedonian expansion in this area, the literary sources, the political institutions, the cults (p. 64f.), and the origin of the population. New texts are marked with an asterisk. Antbemous: A honorific decree was to be set up in the sanctuary of Zeus (A1*, 2nd cent. BC). Dedications to Demeter (A3, ea. 2nd cent. BC), Sarapis, Isis, and Anubis (A6 = SIRIS 112, 1st cent. BC, by a

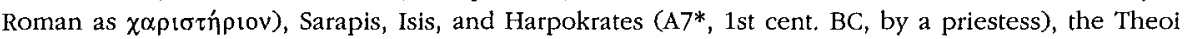
Agoraioi (A4*, 106/5 BC, by two agoranomoi after their term of office), Zeus Hypsistos (A5, 2nd cent. BC). Kalindoia: The priest of Zeus, Dea Roma, and Augustus Apollonios (K2 $=B E 1987,688$; SEG 35,744) is honoured for his benefactions; he funded the monthly sacrifices to Zeus and Augustus, the annual festival ( $\pi \alpha v \eta_{1} \gamma v p$ is) of Zeus and Augustus (with sacrifices, procession, and agon), and an $\ddot{\alpha} \gamma \alpha \lambda \mu \alpha$ of Augustus [on the use of this word, see $E B G R$ 1988, 85]. H.-I. republish with 
an historical and prosopographical commentary the list of priests of Asklepios, eponymous priests of the city (K31 = SEG 36, 626; cf. EBGR 1988, 64]. Dedications to Apollon Pythios and Artemis Hegemone (K3*, late 2nd cent., with representations of Apollon Kitharodos and Artemis Kynegos),

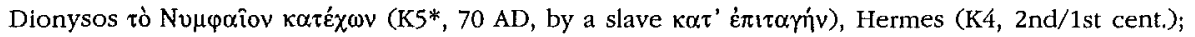
dedication of an altar for a temple (K6, 1st/2nd cent., notice the name Mysta). Notice the use of the term $\ddot{\eta} p \omega \varsigma$ for deceased persons in honorific and grave insciptions (A8*, A12, K15*, K16, K17*, K18, K19*). In an appendix H.-L. republish with topographical commentary the boundary description $E B G R$ 1990, 316 (3rd/2nd cent. BC?; $B E 1990,481$ ) which mentions sanctuaries of Hermes, the Dioskouroi, and Artemis.

93) R.A. HAZZARD, Did Ptolemy I get bis Surname from the Rbodians in 304?, in $Z P E, 93$ (1992), p. 52-56 [BE 1993, 379]: According to PAUS., I, 8, 6 Ptolemy was given the name Soter by the Rhodians in $304 \mathrm{BC}$, but a close study of other statements of Pausanias on the Ptolemies reveals his unreliability as a source. Neither does Diodorus mention this surname among the honours bestowed on Ptolemy by the Rhodians, nor do the Rhodian inscriptions apply this epiklesis, nor does there exist other evidence that an epiklesis was attached to Ptolemy's name in 304 (or during his lifetime).

94) M.-C. Heldmann, Recberches sur le vocabulaire de l'architecture grecque d'après les inscriptions de Délos, Athens-Paris, 1992 [BE 1993, 54]: H.'s important contribution to the study of Greek architecture assembles all the architectural terms attested in the inscriptions of Delos. Besides the discussion of terms related to the architecture and decoration of temples (p. 268-271) the book contains an analysis of many terms of religious significance, i.e.,

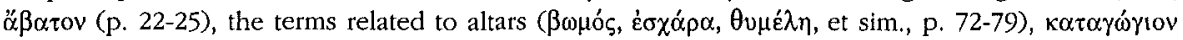

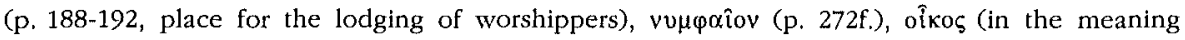
'temple', 'shrine', p. 303f.), $\pi \alpha \sigma \tau o$ ópiov (in the context of the cult of Egyptian deities, p. 327-329),

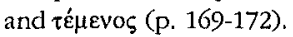

95) P. HERRManN, Epigraphische Notizen 4-9, in EA, 20 (1992), p. 69-73 [BE 1993,

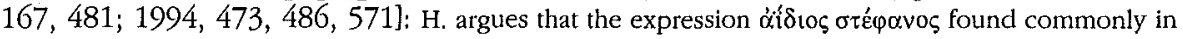
grave inscriptions of Kyzikos does not mean that the deceased was awarded a crown annually (E SCHWERTHEIM's view, see EBGR 1990, 275], but that this honour was proclaimed annually (p. 71). H. restores the expression $\dot{\omega} \oint \theta \varepsilon \hat{\varphi}$ in a grave inscription from Hadrianeia (I.Hadrianeia 179); the deceased is compared to a god (further examples: $B E 1964,596$ ) [and supra ${ }^{\circ} 12$ ].

96) P. HERZ, Asiarchen und Archieriai, in Tyche, 7 (1992), p. 93-115 [SEG 40, 1197]: H.'s thorough study of high priestesses of Asia leaves no doubt that asiarchai and archiereis were not separate officials; while the title archiereus underlined the magistrate's function as high priest of the provincial emperor cult, the title asiarches designated him as president of the provincial council. $H$. argues convincingly that the function of an archiereia became necessary after Drusilla's death (AD 38), when Drusilla's cult was integrated to the imperial cult; Iuliane was the first woman to become archiereia of Asia (I.Magnesia 158). H. also reconstructs the stemma of a family in Kibyra, whose members served as asiarchai and archiereis and points out that the title of archireia was not necessarily given to the wife of the archiereus, but sometimes to his sister or daughter (p. 102) [or mother; $c f$. infra $\mathrm{n}^{\circ}$ 244; also see the remarks of H.W. PLEKET, in $S E G$ 40, 1198].

97) B. HINTZEN-BOHLEN, Herrscherrepräsentation im Hellenismus. Untersucbungen $z u$ Weibgescbenken, Stiftungen und Ebrenmonumenten in den mutterländiscben Heiligtümern Delphi, Olympia, Delos und Dodona, Köln-Weimar-Wien, 1992: The selfrepresentation of Greek cities through dedications in sanctuaries is well attested from the late 6th cent. BC on; this phenomenon became very common after the Persian Wars and formed an important element of self-representation of kings and koina also in the late classical and in the Hell. period. $\mathrm{H}$. collects the respective material (monuments, inscriptions, literary testimonia) for the sanctuaries of Delos, Delphi, Olympia, and Dodona, i.e., honours awarded to kings, members of their families, and officers (esp. statues), royal dedications and foundations, victory monuments, dedications of war booty, and festivals established for or by Hellenistic kings (Delos: Antigoneia 
and Demetrieia founded by the Koinon of the Islanders, Ptolemaia, Philadelpheia, Philetaireia, Antigoneia, Stratonikeia, Paneia, Soteira, Demetrieia, Theuergesia, Philippeia, Attaleia; Delphi: Attaleia, recognition of the Nikephoria in Pergamon and the Eumeneia in Sardis).

98) M. Hockey - A. Johnston - S. LA Niece - A. Middleton - J. Swaddling, An Illyrian Helmet in the British Museum, in ABSA, 87 (1992), p. 281-291 [BE 1993, 112]: Ed. pr. of an Illyrian helmet dedicated to Zeus Olympios, probably by the Koroneans (la. 6th cent. $\mathrm{BC}$ ). The helmet was probably booty from a war between Koronea and another (possibly Boiotian) city.

99) M.C. HoFf, Augustus, Apollo, and Athens, in MH, 49 (1992), p. 223-232: Ed. pr. of a lead token with a representation of the laurel-crowed head of Apollon, the six-rayed star representing the comet or star which heralded the apotheosis of Caesar, and the inscription KAILAP, i.e., Octavian (Athens, ca. $31 \mathrm{BC}$ ). The token may have alluded to Octavian's victory at Actium, representing Apollon Aktios. The inscription probably identified Octavian with Apollon; $\mathrm{H}$. presents ample evidence for Octavian's association with this god, which may have been a response to Antonius' association with Dionysos. In Athens Octavian was honoured as Neos Apollon and his birthday (12 Boedromion) was celebrated in connection with Apollon's birthday (7 Boedromion). The use of the lead token is not known; it may have been exchanged for free gifts (e.g., grain).

100) G.H.R. Horsley, The Mysteries of Artemis Ephesia in Pisidia. A New Inscribed Relief, in $A S, 42$ (1992), p. 119-150 [BE 1993, 95]: Ed. pr. of an honorific inscription for

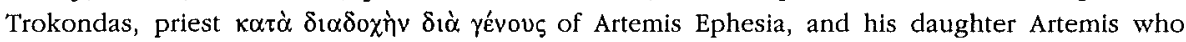
succeeded him, while he was still alive, as priestess of Artemis (Kremna?, 1st c. AD). Trokondas' family had provided the temple and the statue of Artemis; Trokondas watched over the mysteries of

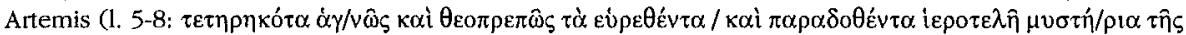

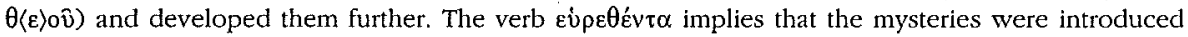
after the discovery of an item, e.g., a written document ('Himmelsbrief'), probably in the 1st c. BC. The priest is represented in relief, wreathed, offering a libation in front of the temple and the statue of the seated goddess. He was succeeded by his daughter Artemis, probably because he had no surviving son. $\mathrm{H}$. offers a thorough commentary focusing on the hereditary priesthoods, the theophoric name Artemis, which the priest of Artemis gave his daughter, the spread of Artemis Ephesia in Asia Minor (esp. in Termessos and Kremna), the links between the officials of the Eleusinian mysteries and the sacred officials at Ephesos, the association of Artemis with Kybele, and the mysteries of Artemis Ephesia (with a list of all the epigraphic attestations). H. discusses the

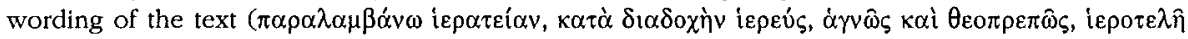
$\mu v \sigma \tau \eta \dot{p i \alpha}$, the latter attested only here) [for $\dot{\alpha} \gamma v \sigma_{\delta} \varsigma$ in the context of mystery cults $c f . E B G R$ 1990, 54]. Following a suggestion made by G. PETZL, H. corrects the reading of a dedication to Artemis Epekoos (SEG 19, 802); the dedicant was 'A temple for Artemis at Kremna (SEG 37, 1175; EBGR 1987, 47), was probably holding a priesthood involving the mysteries of Artemis, as $\mathrm{H}$. infers from the epithet $\pi \alpha v \alpha \gamma$ m $\zeta$, well attested in Athens in the context of the Eleusinian mysteries.

101) C. IÇTEN - H. ENGELMANN, Inschriften aus Ephesos und Umgebung, in ZPE, 91 (1992), p. 283-295: Ed. pr. of a dedication of an altar to Aphrodite Epekoos (3, Ephesos, no date). Ed. pr. of several grave inscriptions mentioning funerary constructions, l.e., $\beta \omega \mu$ ió $(20)$, ทे

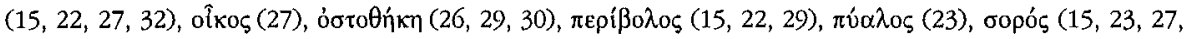

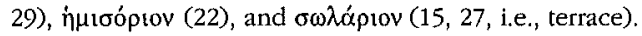

102) L. INNOCENTE, La tribui dei Dordopes, in PP, 47 (1992), p. 446-454: I. discusses the dedication of the phyle of the Dordopes to an Archegetes (Paros, 4th cent. BC, SEG 33, 687). The ethnic name Dordopes belongs to a group of ethnic names well attested in Northern Greece. The dedication of the Dordopes commemorated their coming to Paros, Archegetes being the founder of their colony. [ES] 
103) B. IPLIKÇIOGLU in Zusammenarbeit mit G. ÇELGIN und A. VEDAT ÇELGIN, Epigraphiscbe Forschungen in Termessos und seinem Territorium I (SB Akad. Wien, 575), Wien, 1991 [BE 1992, 511; SEG 41, 1256, 1263-1265, 1268-1272, 1274, 1277, 1278, 1280-1282]: Ed. pr. of 24 inscriptions from Termessos in Pisidia, including a dedication to Hadrian called Olympios (1), an honorific inscription for a winner in wrestling in the agon Sebasteia Solymeia (3, 2nd/3rd cent.), the epitaph of a priest of Zeus (18, 2nd cent. AD), and a

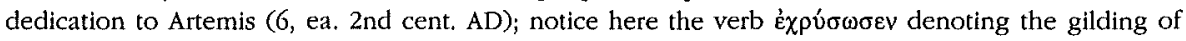
the statue. Grave inscriptions mention fines payable to Zeus Solymeus in case of violation of the grave $(7,9,17,19,20,21,2$ nd-3rd cent. AD); there are ca. 250 attestations of fines payable to this god. Other grave inscriptions (2nd-5th cent. AD) mention the crime of $\tau \nu \mu \beta \omega \rho v \chi i \alpha(9,13,16)$ and fines payable to the city $(8,13,19)$ or the fiscus $(10,16)$. According to a grave inscription the deceased had ordered the burning of his body (11, 3rd cent $A D$; $c f . T A M$ III 356, 562, 689)

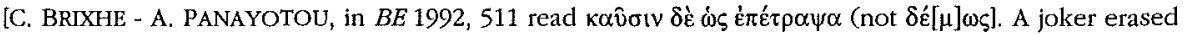

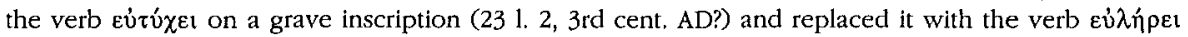
("get mad").

104) B. IPLIKÇIOGLU - G. ÇELGIN - A. VEDAT ÇELGIN, Epigraphische Forschungen in Termessos und seinem Territorium II (SB Akad. Wien, 583), Wien, 1992 [SEG 41, $1259,1266,1267,1285-1290,1294]$ : Ed. pr. of 16 inscriptions (imp.). An inscription (1, ca. 200) commemorates the victory of a boy in wrestling in the commemorative agon for Ti. Claudius Varro and Asklepiodotos; the agon took place under the priesthood of their parents who also functioned as gymnasiarchoi. Their father Timodoros was already attested as priest of Zeus Solymeus for lifetime. Also notice dedications to the local god Kakasbos (3) and an anonymous deity (4) and the epitaph of a priest [of Zeus Solymeus?] (10). Grave inscriptions mention the crime of $\tau v \mu \beta \omega \rho v x i \alpha$ (8, 11) and fines for violation of graves payable to Zeus Solymeus $(6,7,10)$ and the demos $(9$, ei 5 $\dot{\alpha} \sigma \varphi \alpha \dot{\lambda} \varepsilon \varepsilon \alpha \alpha \tau \hat{\omega} \vee \tau \varepsilon \iota \chi \hat{\omega} v, 15)$.

105) B. IPLIKÇIOGLU - G. ÇELGIN - A. VEDAT CELGIN, Neue Inscbriften aus NordLykien I (SB Akad. Wien, 584), Wien, 1992 [cf. SEG 41, 1365, 1370, 1371, 1375, 1376]: Ed. pr. of 15 inscriptions: A honorific inscription for the high priest of the emperor cult M. Aurelius Kiliortes (4, Komba?, under Constantine I) is one of the latest attestations of the emperor cult in the 4th cent. AD. An ampelophylax and priest of Zeus Olympios made a thanksgiving dedication

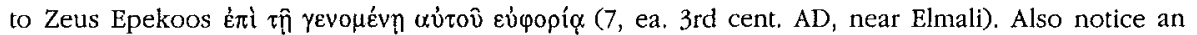
honorific inscription for a priest of Zeus Olympios ( 5 , Terponella?, 2nd cent. AD), and a dedication to the Dioskouroi ( 8 , near Elmali, imp.), Herakles (9, near Elmali), and the $\theta$ eoi oúvvoot

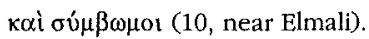

106) S. ISAGER, Sacred Animals in Classical and Hellenistic Greece, in Economics of Cult, p. 15-19: I. collects the epigraphic evidence for livestock owned by sanctuaries (Amorgos, Tegea, Delphi, Delos?) and illuminates the various uses of sacred animals; besides their use in sacrifices and processions, the animals contributed to the income of sanctuaries (through sale of animals, of wool, etc.). (On the inscription from Tegea (LSCG 67) see now L. DUBOrs, Recherches sur le dialecte arcadien, Louvain, 1986, vol. II, p. 20-34. On Delos sew the objections of J. TRÉHEUX, in $E B G R$ 1991, 243. To the epigraphical evidence for sacred animals add I.Cret. II,xi 3 1. 9f. (Diktynnaion, Crete, $6 \mathrm{BC}$ ), which attests the leasing of unfree shepherds and oxen through the sanctuary and the selling of wooll.

107) S. ISAGER, Sacred and Profane Ownership of Land, in B. WELLS (ed.), Agriculture in Ancient Greece. Proceedings of the Seventh International Symposium at the Swedish Institute at Atbens, 16-17 May 1990, Stockholm, 1992, p. 119-122: I. studies some economic and legal aspects related to the ownership of land by sanctuaries. The revenues from the leasing of the sacred land were used for religious purposes (e.g., celebration of festivals). I. argues that the sacred land was liable to taxation when sold or leased. [The scanty evidence neither supports this conclusion nor permits generalizationsl. 
108) A. JACQUEmIN, Thyta et Castalie, in Delphes, p. 167-175: The exact location of Thyiai, a place name mentioned in Delphic inscriptions, is not known. J. rejects the identication of Thyie/Thyiai with Thystion (AESCH. III, 122). The mythological traditions concerning Thyia, daughter of Kastalios, associate her with Kastalia, and this implies that the temenos of Thyia was located in the eastern part of the sanctuary.

109) J. JARRY, Nouvelles inscriptions de Syrie du Norde (suite), in ZPE, 90 (1992), p. 103-112: Ed, pr. of 22 inscriptions from Northern Syria. Among them a dedication in fulfillment of a vow (10, Lubnan, $231 \mathrm{AD})$, two grave inscriptions of priestesses $(15,19$, 'Is, imp.), and a funerary imprecation (22, Rbeita).

*110) S.I. Johnston, Hekate Soteira: A Study of Hekate's Roles in the Chaldean Oracles and Related Literature, Atlanta, 1990: J. portrays the prominent rôle of Hekate in the 'Chaldean Oracles' of the late 2nd cent. AD, esp. her association with the cosmic soul and her rôle in theurgy and magic (esp. in the magical papyri). Hekate was chosen to play the rôle of an intermediary between the worlds of men and of gods or between the spheres of the Sensible and the Intellegible, because of her earlier association with liminal points (e.g., crossroads, doorways, etc.) [cf. $E B G R$ 1991, 115]. Hekate's conception in late antiquity roots in her earlier nature as a guide across boundaries, esp. across the boundary between the underworld and the world of the living (p. 21-28). Some epigraphic evidence is considered in the chapter about Hekate's earlier nature, e.g. the rites performed for Hekate in the procession of the molpoi in Miletos (LSAM 50, p. 21 note 3) [cf. supra $\mathrm{n}^{\circ}$ 67] and the key-procession in Stratonikeia (p. 41f.). The latter ritual is associated with Hekate's perception as a key-holder, her rôle as intermediary, and her association with passages and liminal points. [On Hekate Kleidouchos see also A. KEHL, $s, v$., in RAC 14 (1988), p. 319f, On Hekate Enodia (p. 23f.) see now $E B G R$ 1991, 43; on Hekate Pheraia (p. 27) $c f . E B G R$ 1990, 216. For Hekate's popularity in late antiquity $c f$. her invocation in alphabetical oracles: $c f . E B G R$ 1988, 23. Her association with liminal points and her rôle as guide and intermediary is also reflected in her association with Hermes; see, e.g. I.Trallets 11-12 (dedications of Hermes statues by priests of Hekate); $E B G R$ 1990, 321 (invocation of Hermes Eriounios and Hekate in a curse)].

111) S.I. JOHNSTON, Riders in the Sky: Cavalier Gods and Theurgic Salvation in the Second Century A.D., in CPb, 87 (1992), p. 303-321: To shed new light on the religious movement of the theurgists of the late 2nd cent. $\mathrm{AD}$, J. studies one particular magical epiphany, that of a divinity which will manifest himself to the theurgist as a child, either covered with gold or naked, riding on a horse and shooting a bow and arrow (cf. Chald. Oracle fr. 146, an oracle probably spoken by Hekate). The epigraphic and iconographic material provides ample evidence for divine horsemen, usually conceived as saviours (e.g., the Dioskouroi, Horus/Harpokrates, Mithras, the Jewish Logos figure, the Danubian Rider, the Gallic Jupiter, and the Thracian Rider God Heron, worshipped with the epithets Theos Sozon, Epekoos, Soter, Thaumatourgos, Panthopoios, Agathopoios, Katoikadios, and Propylaios). The popularity of these divine horsemen in the first three centuries $A D$ indicates that the interest of the theurgists on this soteriological figure was part of a general religious development. The weaponry and armour of the riding divinity as described in the Chaldean oracle can be associated with the contemporary iconography, which was influenced by military movements. The attributes of this divine horseman represent useful knowledge and protection and are associated with the battle of the magician against a demonic onslaught. This example shows that the movement of the theurgists was not disconnected from other Mediterranean religious trends of the 2nd cent. AD.

112) D.R. JORDAN, The Inscribed Lead Tablet from Phalasarna, in ZPE, 94 (1992), p. 191-194 [BE 1993, 106]: After autopsy of the lead tablet of Phalasarna (ca. 300 BC, I.Cret. II,xix 7), now in the National Museum at Athens, J. offers a tentative new text. According to this reconstruction the metrical text was intended to avert evil ( $c f$. the first lines: "I bid you to flee from these houses of ours... I call on Zeus the averter of ills, Herakles the sacker of cities, Iatros, Nike, Apollon"). 
113) F. KAYSER, Oreilles et couronnes. À propos des cultes de Canope, in BIFAO, 91 (1992), p. 207-217 [BE 1992, 565; SEG 41, 1628-29]: The dedicatory reliefs with representa-

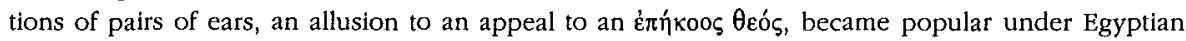
influence. K. edits two inscribed reliefs (SB I 1603 and an unpublished piece), with representations of pairs of ears and the atef-crown, an attribute of Osiris (2nd cent. AD); the first relief was dedicated by a freedman to Isis, the other by Arrian, probably to Osiris. K. argues that these reliefs were dedicated in the sanctuary of Sarapis and Osiris at Kanopos, where Isis was also worshipped.

114) E. KEARNS, Between God and Man: Status and Function of Heroes and their Sanctuaries, in Le sanctuaire grec, p. 65-99: General presentation of the common features shared by sanctuaries of heroes, with particular focus on their similarities to sanctuaries of gods, their location (esp. near water sources or on mountains and hills), the rôle of heroes as protectors of cities, and the links between sanctuaries.

115) D. KNOEPFLer, Sept années de rechercbes sur l'épigrapbie de la Béotie (19851991), in Chiron, 22 (1992), p. 411-503 [BE 1993, 268]: Useful annotated bibliography of recent research in Boiotian inscriptions, including several lemmata on cults and agons ( $\mathrm{n}^{\text {os }} 45-49$ ). K. modifies the view of P. ROESCH $\left(n^{\circ} 47\right)$ that the diffusion of Egyptian cults in Boiotia was the result of Boiotian diplomatic contacts with the Ptolemies. The list of proxenoi and benefactors who represented their states in a festival in Boiotia $(S E G 37,388)$ is not necessarily related to Thebes, as suggested by V.N. BARDANI. It records the first celebration of a new agon or the reinstitution of an agon, after an interruption, e.g., during the Mithridatic War (for a similar interpretation see $E B G R$ $1989,10 ; 1991,13]$. K. also discusses the cult of Herakles Leuktriades in Thespiai $\left(n^{\circ} 106\right)$ and the documents concerning the agons Basileia in Lebadeia $\left(n^{\circ} 157\right)$ and Charitesia in Ochomenos $\left(n^{\circ} 161\right)$.

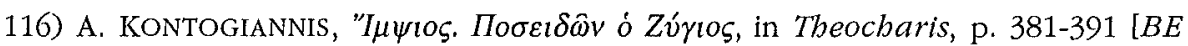
1993, 322]: K. restores the epithet Impsios in four dedicatory inscriptions addressed to Poseidon from Nikaia (ancient Chalke?, on the territory of Larisa) in Thessaly (3rd cent. BC). The epithet Impsios is epigraphically attested only in Thessaly; it means Zúvios (HESCH., s.v., cf. the epithet Zev $\xi_{\alpha} v \theta 10 \xi$, also attested for Poseidon in Thessaly) and is the Thessalian equivalent to "I $\pi \pi 10 \varsigma$. [ES]

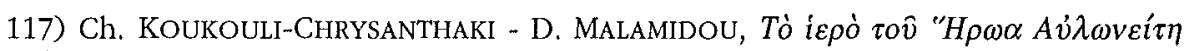
$\sigma \tau \dot{o}$ M $\alpha \gamma \gamma \alpha \hat{\imath} o$, in $A E M T, 3$, p. 553-567 [BE 1992, 323; SEG 40, 539]: The sanctuary of the rider god Heros Auloneites, whose cult is known from dedicatory inscriptions, was found between Kepia and Akrobouni on the foot of Mt. Pangaion; it was in use from the Hell. period to the 4th cent. AD. As the name of the hero indicates (from $\alpha \dot{u} \lambda \operatorname{siv}^{2}$, 'strait, passage'), he was regarded as protector of passages. Numerous graffiti on pottery (with the worh tors) were found in the sanctuary; in the inscription on a Hell. relief the hero is called $\dot{\varepsilon} \pi \hat{\eta} \kappa o \circ \varsigma$ ). Several jugs (imp.) bear sealings with the inscription ñpwos and the abbreviations $\Theta \mathrm{E}$ and HP. Notice also a dedication of a Roman officer.

*118) R.S. KRAEMER, Her Share of the Blessing: Women's Religions Among Pagans, Jews, and Cbristians in the Greco-Roman World, New York-Oxford, 1992: Comprehensive study of the religious activities of women [the term 'women's religions' is inappropriate] against the background of the social constraints for women and the definiton of their rôles in Greek and Roman society. K. makes extensive use of epigraphic sources in her discussion of women's devotion to Dionysos, esp. in Asia Minor (p. 36-49) [cf. infra $\mathrm{n}^{\circ}$ 150; EBGR 1991, 46-47)] and Isis (p. 71-79), and the religious offices held by women (p. 80-92) [cf. supra $\mathrm{n}^{\circ} 50$, infra $\mathrm{n}^{\circ} 206$ ].

119) C. KRITzAS, Aspects de la vie politique et économique d'Argos au Ve siècle avant J.-C., in Polydipsion Argos, p. 231-240 [BE 1993, 259; SEG 41, 282, 284, 291]: $K$. sketches the process of democratization and the expansion of Argos in the first half of the 5 th cent. BC. He mentions an unpublished bronze tablet of the late 4th cent. which concerns payments made by a collegium of magistrates ('the Twelve') to the twelve phratries, the hodelonomoi, and the two hierothytai [on this office see infra $\mathrm{n}^{\circ} 243$; this text is mentioned in $E B G R$ 1991, 134]; the 
text also attests that the money from the sale of the skin of sacrificial animals was spent for the celebration of the pentaeteris, i.e., the Heraia (p. 235f.). Another unpublished inscription of the late Hell. period (p. 237-240) refers to the services of an official who managed to give back to the sanctuaries of Hera (i.e., the Argive Heraion), Herakles (near Tiryns?), Apollon Pythaeus (at Asine), and Alektryon (at Midea) their sacred land, which had been usurped by some citizens. This sacred land was probably allotted to the sanctuaries after the Argive expansion of the 5 th cent. The same

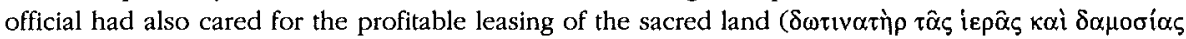
$\chi(\omega \rho \alpha \varsigma)$, thus securing large revenues for the city; it is obvious that the money collected from the

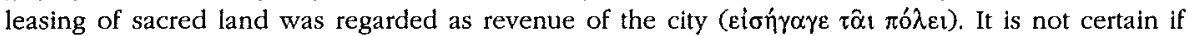
Alektryon is a male name (the father of Alkmene, king of Midea) or the second name of Alkmene, Herakles' mother. K. also mentions an unpublished boundary stone of the sanctuary of Apollon Pythacus found near Iria (southeast of Asine, 4th cent. BC, p. 239).

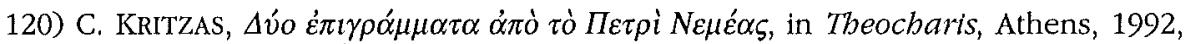
p. 398-413 [BE 1993, 256; SEG 41, 273]: Ed. pr. of two epigrams from Petri in Nemea (Keleai?), written by Aristomenes on a monument dedicated to his ancestors Flavianus from Korinth and Salvia from Thessaly (2nd cent. AD). Salvia is claimed to have descended from Achilleus' father,

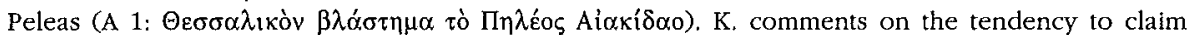
heroic ancestry in imp. times (p. 402). The dedicant most probably belonged to the prominent Korinthian family of the Gellii, who had friendly contacts with several scholars, like Herodes Atticus and Arrian. K. argues convincingly that APULEIUS in the Metamorpboseis is alluding to the Salvia of this inscription, when he mentions a Salvia from Thessaly, the wife of a Korinthian nobleman.

121) U. KRON, Heilige Steine, in Kotinos, p. 56-70: K. sketches the significance of 'sacred stones' in Greek religion, focusing esp. on the aniconic representations of gods, on baetyls, meteorites, argoi lithol, and pebbles dedicatied to gods [cf. also C. FARAONE, supra $\mathrm{n}^{\circ}$ 67, p. 5f.]. Several 'sacred stones' were inscribed, e.g., the herms in Tegea, monoliths in Elea inscribed with the letters EP, probably dedications to Eros, a pebble dedicated to Aphrodite in Kamarina, the argol litboi of Antipolis dedicated to Aphrodite, the stones found near the agora of Metapontion, dedicated to various deities, esp. Apollon Lykeios. The interpretation of the latter stones is a matter of controversy (aniconic representations of gods, dedications, boundary stones?) [Cf. EBGR 1991, 88]. The study of this material demonstrates that 'sacred stones' fulfilled a great variety of functions (aniconic representations, apotropaic symbols, dedications) and that generalisations should be avoided.

*122) U. KRON, Frauenfeste in Demeterbeiligtimem: Das Thesmopborion von Bitalemi, in $A A, 1992$, p. 611-650: K. presents the material found in the sanctuary at Bitalemi (near Gela), which has been identified as a Thesmophorion thanks to an inscription (EBGR 1989, 29

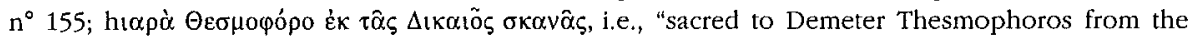
'tent' of Dikaio"). The objects found here (terracottas, pottery, lamps, jewelry, pebbles, various cult and sacrificial implements, loom weights) are related to the rituals of the Thesmophoria. $\mathrm{K}$. discusses in detail the literary evidence concerning the Thesmophoria, esp. in Athens, the use of 'skenai', and the cultic prescriptions for the skenai.

*123) D.G. KYLE, The Panathenaic Games: Sacred and Civic Atbletics, in Goddess and City, p. 76-101: Study of the program of the Panathenaic contests and the significance of the festival for the civic identity in Athens.

124) A. LAJTAR, Ein zweiter Beleg fir doumos in Thessalonike, in ZPE, 94 (1992), p. 211-212: L. recognizes in $I G \times 2,860$ Thessalonike (2nd/3rd cent.) another attestation of the word $\delta 0 \hat{v} \mu \circ \varsigma$ ('association') and presents further evidence for professional associations and for grave monuments erected by associations for their deceased members [cf. infra $\mathrm{n}^{\circ} 237$ ]. 


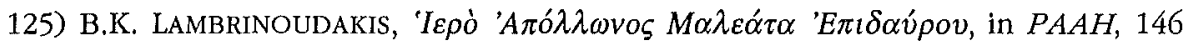
(1991) [1994], p. $70-78$ [SEG 41, 304]: L. mentions two dedications of pyrphoroi (Hell. and imp. times) and an altar dedicated to Hera (4th cent.) found in the sanctuary of Apollon Maleatas in Epidauros (p. 70).

126) G. LAMINGer-PASCHER, Die kaiserzeitlichen Inschriften Lykaoniens. 1. Der Süden (Ergänzungsbände zu TAM, 15), Wien, 1992 [BE 1993, 771]: Corpus of the inscriptions of Lykaonia (imp., all the texts of religious interest were already published). Ilistra-Kassaba:

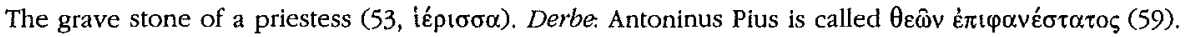
Barata: A woman, who dedicated the grave inscription of her husband, uses the expression

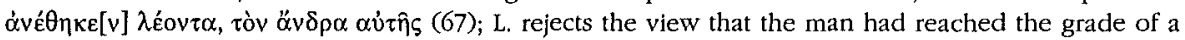
leo in the Mithraic mysteries and assumes that the woman dedicated the statue of a lion, as guardian of the grave. [Notice, however, that the son of the deceased has the name Leontion, 'the

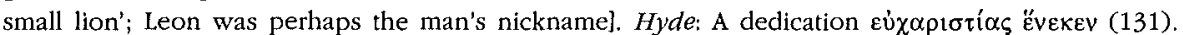

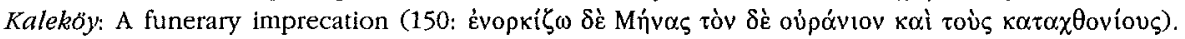
Thebesa: A dedication to Artemis with the epithet Astai[--], probably deriving from a place name (153). Lystra: A dedication to Ploutos (4th cent. AD); an altar dedicated by a hieros thiasos to Apollon, i.e., probably to Augustus, identified with Apollon [cf. supra $\mathrm{n}^{\circ}$ 99]; two funerary impreca-

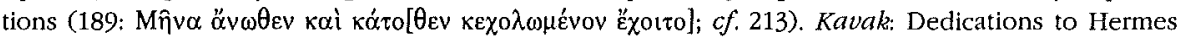
and another god with the epithet Epekoos (227) and to Ge (228). Akviran: A dedication to Athena

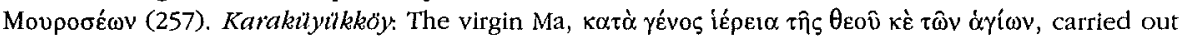
some contructions in a temple, probably of a mystery cult (293); the priest Theophilos dedicated an altar to Dionysos and Pantheos (294). Also notice the usual accusations against $\beta \alpha \dot{\sigma} \sigma \alpha v \vee \varsigma \varsigma$ $\delta \alpha i \mu \omega v$ (Dinoma, 242) and $\varphi \theta 0$ vos (406, Dorka) in grave inscriptions.

127) L.R. LIDONNICI, Compositional Background of the Epidaurian Iamata, in AJPh, 113 (1992), p. 25-41: L. gives an overview of the collection of healing miracles from the Asklepieion of Epidauros (4th cent.) and illuminates the way it was formed. The various afflictions mentioned in the iamata are related to those cured by profane medicine, but the healing described in the iamata has a miracular character [for the assimilation of these healing miracles to the profane medicine see A. CHANIOTIS, Illness and Cures in the Greek Propitiatory Inscriptions and Dedications of Lydia and Phrygia, in Ph.J. VAN DER EIJK - H.F.J. HORSTMANSHOFF - P.H. SCHRIJVERS (eds), Ancient Medicine in its Socio-Cultural Context, Amsterdam-Atlanta, 1995, II, p. 335l. L. suggests that the reading and discussion of the iamata must have been an important preparatory activity before the incubation. The collection in its present form is an amalgamation of earlier inscriptions, votives, and oral traditions. It incorporates texts of inscriptions removed from the sanctuary during the process of its monumentalization in the 4th cent.; in this way the iamata reflect the text of earlier inscriptions and pictorial representations.

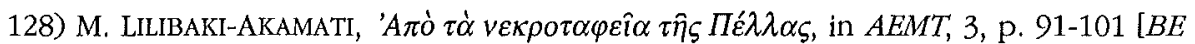
1992, 307]: Mention of two gold laurel leaves found in two cist graves in Pella (la. 4th cent. BC).

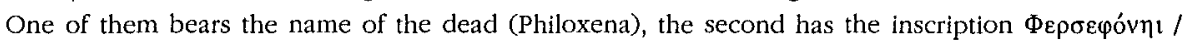

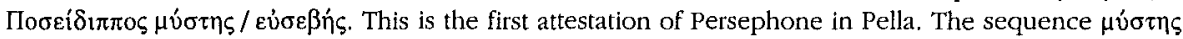

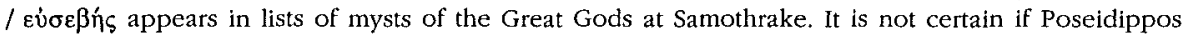
had been initiated in one of the panhellenic mystery cults or in a particular cult of Persephone in Pella. [M.B. HATZOPOULOS, in $B E 1992,307$, reminds that the expression is used in a funerary epigram from Lete (SEG 31, 633), where an important sanctuary of Demeter existed. For similar golden leaves with the names af the deceased designated as mysts $c f . E B G R$ 1991, 177 (Aigion)].

129) T. LINDERS, Sacred Finances: Some Observations, in Economis of Cult, p. 9-12: Focusing on the sanctuaries of Apollon in Aktion and Delos L. sketches the various aspects of cult finances (revenues, expenses for cult) and defines the economic rôle(s) of sanctuaries in the world of the Greek city (banking activities, employment of labour, consumption of goods): "The sanctuary resembled Weber's city in that - on the whole - it lived on contributions and did not produce any material goods. I suggest, however, that what we may call its spiritual wares, the cult, created a 
demand for certain material commodities, which stimulated production and provided the producers with a market they might not otherwise have had" (p. 11).

130) T. LINDERS, Inscriptions and Orality, in SymbOsl, 67 (1992), p. 27-40: In this stimulating article $\mathrm{L}$. studies the temple inventories of Athens and Delos as examples of oral communication (here, between officials). Several discrepancies appear from one year to another: Groups of votives may be omitted or mentioned in a different sequence from one year to another. L. supports her view that the aim of the inventories was not administrative, as records, but symbolic, as an expression of the piety of the officials [cf. EBGR 1988, 100 and infra $\mathrm{n}^{\circ} 131$ ].

131) T. Linders, The Delian Temple Accounts: Some Observations, in OpAth, 19 (1992), p. 69-73: L. argues that the temple inventories of Delos were not primarily 'book-keeping records' of the dedications, but an expression that the sacred officials had fulfilled their administrative duties with piety [for the same view $c f . E B G R$ 1988, 100 and supra $\mathrm{n}^{\circ} 130$ ].

132) T. LoCHMan, Une stèle phrygienne, in Revue du Louvre, 6 (1990), p. 455-461 [SEG 40, 1241]: Ed. pr. of a relief aquired by the Musée Calvet (ea. 3rd cent. AD) with a representation of the two deceased persons, a triple Hekate, Mes, Demeter, Zeus, Helios, and Selene. A group of relatives dedicated to Hekate Soteira Tateis and her son. The inscription reads: 'A $\alpha \alpha \theta \hat{\eta}$,

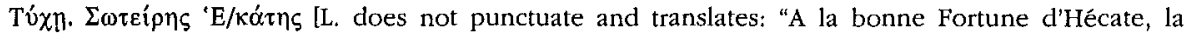

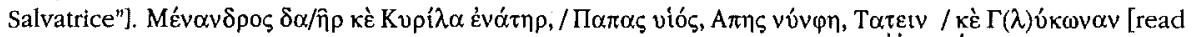

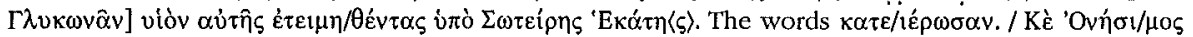
$\tau \varepsilon / \theta \rho \varepsilon \mu \varepsilon ́ v / o \zeta \quad \alpha \pi \varepsilon \varepsilon \varepsilon \rho / \omega / \sigma \varepsilon / v$ were added above the text. Grave stones dedicated to Hekate are common in Phrygia; sometimes a god (Zeus or Hekate) is mentioned as "honouring" the deceased. L. discusses the iconography and the typology of Phrygian grave stones.

133) T. LOCHMAN, Eine Gruppe spätrömiscber Grabsteine aus Pbrygien, in E. BERGER (ed.), Antike Kunstwerke der Sammlung Ludwig III, Mainz, 1990, p. 453507 [SEG 40, 1291; $B E$ 1994, 562 bis]: L. studies, with ample archaeological and epigraphic commentary, seven inscribed funerary reliefs from Phrygia ( $\mathrm{nd} / 3 \mathrm{rd}$ cent. AD). According to one of them (258) the deceased was hnoured by Soteira Hekate (cf. supra $\mathrm{n}^{\circ} 132$ ). L. argues that the epithet reflects the belief that Hekate could free the souls of the deceased and lead them from the underworld. [ES]

134) M. DEL AMOR LÓPEZ JimeNo, $Z$ u einer Flucbtafel vom Athener Kerameikos, in $Z P E, 91$ (1992), p. 201-202 [BE 1993, 105]: L, restores the last lines of a defixio against legal opponents (Kerameikos, 4th cent. BC) [EBGR 1990, 321, I 515]; the text should be read tò ouv8[ixos]

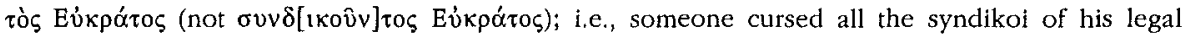
opponent Eukrates. Syndikoi are often mentioned in Attic defixiones.

135) F.G. LO PORTO, Timmari: L'abitato, le necropoli, la stipa votiva, Rome, 1991: Two new epigraphic finds provide further evidence for the cults of Persephone and Aphrodite, already attested through archacological finds (dedications) in Timmari. A bowl bears the invocation $\Pi \alpha \hat{\imath}$, i.e., Kore/Persephone (la. 2nd. cent. BC); a sherd of an Apulian vase is inscribed with the name of Aphrodite.

136) $\mathrm{H}$. MALAY, $\Theta v \mu o \lambda v \tau \varepsilon \hat{i} v$ and $\theta v \mu o \lambda v \sigma i \alpha$ and the Cult of Apollon Axyros in Lydia, in $E A, 20$ (1992), p. 75-76 [BE 1994, 509]: Ed. pr. of a new confession inscription from Saittai. Throphimos was punished for disregarding ( $\pi \alpha \rho \hat{i} \delta \varepsilon$ ) his mother-in-law, and after his propitiation ( $(\dot{\theta} \theta \mu \mathrm{v} \lambda \dot{v} \tau \eta \sigma \varepsilon)$ he dedicated a stele to Apollon Axyros. This texts permits the interpretation of the words $\theta v \mu \circ \lambda v \tau \varepsilon i v$ ('mitigate the divine wrath') and $\theta v \mu \circ \lambda v \sigma i \alpha$ [cf. EBGR 1989, 123] and gives the correct form of the epithet of Apollon Axyros (not Azyros as in SEG 37, 1737). Notice the use of the expressions $\sigma \tau \eta \lambda_{0 \gamma \rho} \alpha \varphi \varepsilon \hat{v} v$ and $\varepsilon \dot{v} \chi \alpha \rho ı \tau \varepsilon \hat{\imath}$, common in confession inscriptions.

137) G. MANGanaro, Istituzioni pubbliche e culti religiosi, in L. BRACCESI - E. DE MIRo (eds), Agrigento e la Sicilia greca. Atti della settimana di studio, Agrigento, 28 maggio 1988, Roma, 1992, 207-218: Using the epigraphic evidence (also some inedita) M. discusses briefly the cults of Akragas, which include those of Zeus Atabyrios, Zeus Soter, Zeus 
Exakester ("dio purificatore"), Eleithyia (mentioned on a still unpublished sherd), Polystephanos Soteira, and Apollon ( $c f$. the month name Karneios). The influence of Akragas' mother cities (Gela and Rhodos) is evident in the cults. M. associates a graffito on a vase with the text [--]MNAMO[--] with the graffito $\Theta \varepsilon ́ \sigma \tau \alpha v \mu v \alpha \dot{\mu} \omega \nu$ (Phintias, near Gela) and interprets both texts as references to the Nymphs [but see $E B G R$ 1988, 42: thestai is the designation of a cult association].

138) G. MANGANARO, Tra epigrafia e numismatica, in Chiron, 22 (1992), p. 385-410 [ $B E$ 1993, 722]: $M$. edits four stone inscriptions from Lipara (p. 388-390): 1) A dedication to Isis (?) Thea Epekoos, originally thought to be a dedication to Artemis [G. MANGANARO, in $P P, 20$ (1965), p. 176f.]; 2) an altar dedicated to Aphrodite (?); 3) a funerary inscription, written on an altar originally dedicated to Apollon (?). 4) An inscription recording a construction related to a

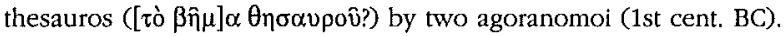

139) J. MANGAS, El culto de Appolo en Hispania. Testimonios epigráficos, in Mélanges Lévêque, 6, p. 171-192: Collection of 26 Latin inscriptions from various cities of Spain, which attest Apollon's cult, esp. as a healing deity. This cult seems to have been particularly supported by the local elites.

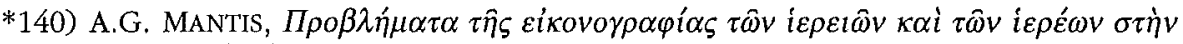
$\dot{\alpha} \rho \chi \alpha i ́ \alpha \dot{\varepsilon} \lambda \lambda \eta v \imath \kappa \dot{\eta} \tau \dot{\varepsilon} \chi v \eta$, Athens, 1990: Study of representations of priests and priestesses (esp. bearers of keys and xoana) in the archaic and classical art. The 'small temple' at Rhamnous is usually interpreted as a temple of Themis, because a colossal statue was found there. The inscriptions found there do not support this identification (p. 104-113); they record joint dedications to Nemesis and Themis, who must have been worshipped together, but not in the 'small temple'.

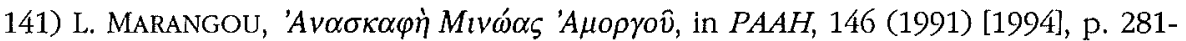
305: A vase probably dedicated to Dionysos was found in a sanctuary in the acropolis of Minoa (Amorgos, 4th cent., p. 287).

142) J. MARCILLET-JAUBERT, Une nouvelle inscription grecque à Falaika, in Y, CALVET - J. GACHET, Falaika. Fouilles françaises 1986-1988, Paris, 1990, p. 193-195: Ed. pr. of a dedication by an Athenian mercenary to Poseidon Asphaleios, found in the fortress on Falaika/Ikaros ( $3 \mathrm{rd}$ cent. BC). The same person appears in another dedication of soldiers to Zeus Soter, Poseidon, and Artemis Soteira [cf. EBGR 1990, 249].

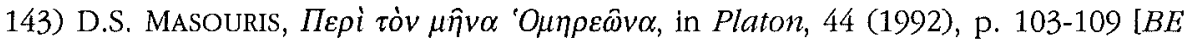
1993, 22]: M. discusses $I G$ XII 5, 15 (Ios), which mentions a sacrifice to be offered on the 16th day of the month Homereon. The literary sources imply that this day was the anniversary of Homer's death. The literary tradition which affirms that Demosthenes died on the same day as Homer (16 Pyanopsion) permits the identification of the month Homereon with Pyanopsion. $M$. argues that in Ios the sacrifice to Homer was offered during the festival Thesmophoria.

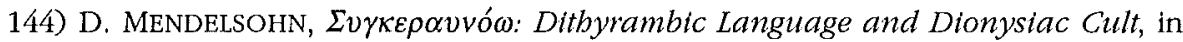

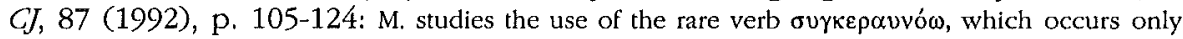
three times in classical literature, always in Dionysiac contexts (ARCHIL., fr. 77B; KRATINOS, fr. 199 K-A; EURIP, Baccb. 1103), arguing that it is a survival from the vocabulary of early Dionysiac cult dithyramb. The verb ('utterly blasted with lightning') expresses the elements of drunken inspiration and sudden, violent destructiveness, which seem to be related to early cult dithyramb. In this context $M$. presents the evidence for the rôle of thunder in Dionysos' myth (the god's birth and Semele's death) and possibly also in the Dionysiac mysteries. There is a reference to death by

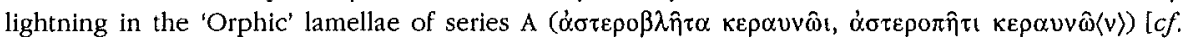
$E B G R$ 1989, 21], perhaps an allusion to the crime of the Titans. The abrupt appearance of a brilliant light, an allusion to the lightning that punished the Titans, may have been part of the initiaton. The initiate, lightning-blasted like the Titans, escaped from the evil through his punishment for unjust deeds "and found the better". 
145) R. Merkelbach, Aurelia Artemisia aus Epbesos, eine gebeilte Augenkranke, in $E A, 20$ (1992), p. 55 [BE 1994, 496]: M. republishes the dedicatory relief of Aur. Artemisia (ed. pr.: W. HORNBOSTEL, in Jabrbucb Hamburger Kunstsammlungen, 23, 1978, 215s.), addressed to Theos Epekoos Hypsistos. Artemisia dedicated the relief in fulfillment of a vow, after her eye

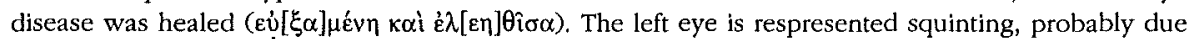
to a temporary paralysis of the nervus abducens.

146) T.B. MITFORD, Inscriptiones Ponticae. Sebastopolis, ZPE, 87 (1991), p. 181-243 [SEG 41, 1112, 1119]: M. presents a corpus of the inscriptions of Sebastopolis, partly presented in $E B G R$ 1991, 166 (new texts are marked with an asterisk). The honorific inscription for a high

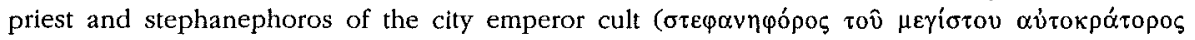

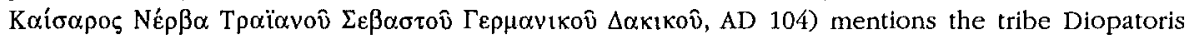
(11*) [probably named after Zeus Pater or Patroios; for tribes named after gods see EBGR 1988, 75, $117 ; 1990,166]$. A prominent citizen, high priest of Hadrian for lifetime (with his wife), is honoured for his services; he organized many spectacles and served often as thiasarches (12). For another high priest see $n^{\circ} 20$ (2nd cent. AD). Caesellia Maxima, matrona stollata and high priestess, proudly bore the name Amazonis (19,2nd/3rd cent.); according to a local tradition the land of the Amazons was not far from Sebastopolis, in the plain of Iris and Thermodon. The metric grave inscription for Theotima mentions the establishment of a temenos, with an altar surrounded by a grove $\left(24^{*} 1.14-16\right)$. A grave inscription is dedicated to $\theta$ coi $\alpha \alpha \tau \alpha \chi \theta$ óv1ol $\left(28^{*}\right)$.

147) V. Mitsopoulos-LeON, Bronzekästchen fïr Artemis, in Eumusia, p. 137-140 [SEG 40, 370]: Presentation of three bronze boxes dedicated to Artemis Hemera at Lousoi, one of them inscribed with the name of the goddess and that of a male dedicant (la. 4th cent. BC). Another inscribed box was known already, also inscribed with the name of a man. Bronze boxes are typical female dedications; this explains perhaps why male dedicants chose to write their names.

*148) J. MOLTHAGEN, Die ersten Konflikte der Christen in der griechisch-römischen Welt, in Historia, 40 (1991), p. 41-76 [BE 1992, 402; SEG 41, 918]: M. (p. 47 n. 27) comments on the term $\theta \varepsilon 0 \sigma \varepsilon \beta \varepsilon i \varsigma \zeta$ (proselytes) in an inscription of Aphrodisias concerning the local Jewish community (SEG 36, 970; EBGR 1987, 95; cf, infra $\mathrm{n}^{\circ} 209$ ). With regard to the title asiarches $M$. rejects R.A. KEARSLEY's view that the titles asiarches and archiereus denote two different offices in the province Asia [cf. supra $\mathrm{n}^{\circ} 96$ and infra $\left.\mathrm{n}^{\circ} 244\right]$.

149) L. MORETTI, Dagli Heraia all'Aspis di Argos, in $M G R, 16$ (1991), p. 179-189

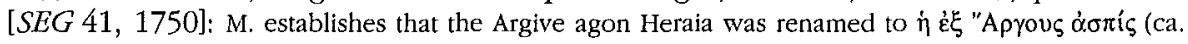
AD 85); the older name was still used later, in exceptional cases.

150) A. MOTTE - V. PIRENNE-DELFORGE, Le mot et les rites. Apercu des significations de ö $\rho$ i $\alpha$ et de quelques dérivés, in Kernos, 5 (1992), p. 119-140: In this general study of the use of the term orgia in the cults of Demeter, Dionysos, Hekate, the Samothrakean gods, Aphrodite, and the Muses, notice a collection of the epigraphic attestations of the term in relation to Dionysos' cult in Miletos, Magnesia, and Delphi (p. 129 n. 37-39).

151) H. Müller, Pbyromacbos im pergamenischen Nikepborion?, in Chiron, 22 (1992), p. 195-226 [BE 1993, 70; SEG 40, 1131]: M. disproves B. ANDRAE's speculations about the place where Phyromachos' statue of Asklepius was set up; ANDRAE's views were based on misinterpretations of the literary and epigraphic evidence (esp. POLYB., XXXII, 15, 1-8; OGIS 332, an honorific decree for Attalos III concerning the erection of his statue in the Asklepieion). M. demonstrates that only one sanctuary of Asklepios existed in Pergamon, that the statue made by Phyromachos was set up in Asklepios' temple outside the city (not in the sanctuary of Athena Nikephoros), and that the inscription found in 'temple $\mathrm{R}$ ' of the gymnasium is not a dedication to Asklepios, but simply names an official with a theophoric name (e.g., Asklepiodoros). 
152) D. MulliEz, Un document financier inédit de la fin du ITe siècle av. n.è., in Delphes, p. 317-332 [BE 1993, 276]: Ed. pr. of a leasing or loan contract (la. 2nd cent. BC) between a citizen of Delphi and the sanctuary. It is the earliest attestastion of the bosioi, a collegium of five officials. An individual was to pay annually, in four installments, an amount to the hosioi; the document mentions the guarantees and penalties if the contract was not fulfilled. The duties of the hosioi were obviously not limited to religious matters, but covered also the financial interests of the sanctuary.

153) D. MulliEz, Les actes d'affranchissement delphiques, in Cabiers du Centre G. Glotz, 3 (1991), p. 31-44 [BE 1992, 278]: M. gives an overview of the manumission documents in Delphi, focusing on the formulaic expressions of the inscriptions (manumission as 'sale' to Apollon), the provenance of slaves, the procedure of manumission and its evolution. [ES]

154) M. NAFISSI, Mageirike skeue e sacrificio nel territorio di Taranto, in PP, 47 (1992), p. 132-146 [BE 1993, 471, 484, 712]: Reedition of the archaic inscription from Taras with a list of cult implements [EBGR 1987, 65;1989, 30;1990, 3 and 243]. N. proposes several restorations and interpretations of the objects (1. 7: * $\sigma \mu \varepsilon v i \alpha$, 'axts'; 1. 8: $\sigma \kappa \alpha \varphi[i \delta \alpha 1]$, 'cooking pots'; 1. 8f.: ${ }^{*} \kappa \rho \varepsilon o \delta \alpha^{\prime} \theta \varepsilon \alpha$, 'hook for the meat'). $N$. establishes that the objects listed here were related to the sacrifice and the cooking of the meat of sacrificial animals [cf. EBGR 1990, 3]; the text is not necessarily an inventory [the view of L. DUBOIS], but a list of objects dedicated (by the city?) to the

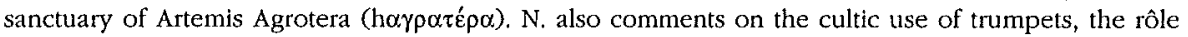
of the hierokeryx, and the cult of Artems Agrotera, a goddess associated with the borderland.

155) A.M. NAGY, EYOПАI EYTYXI, in Bulletin du Musée Hongrois des Beaux-Arts, 76 (1992), p. 15-29: Ed. pr. of a small bronze bell of unknown provenance with an engraved

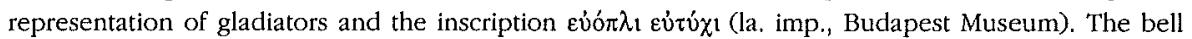
was probably used as an amulet. While the wish evirúxet is common on amulets, this is the first attestation of $\varepsilon \dot{v} o \dot{ } \pi \lambda \varepsilon 1$, obviously an encouragement to a gladiator to use his weapons successfully. $N$. collects numerous examples of similar bells, often inscribed with wishes of the type $\varepsilon \ddot{b} \pi \lambda_{01 \alpha}$,

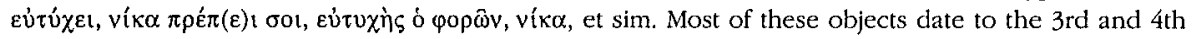
cent.

156) A.M. NAGY, Ein kaiserzeitlicher Talisman, in $A A, 1992$, p. 99-108 [BE 1993, 123]: Ed. pr. of a chalcedony gem with the representation of an eagle holding a crown with his beak (Budapest Museum). The owner of the stone, Asklepiakos, invokes all the angels to give him success,

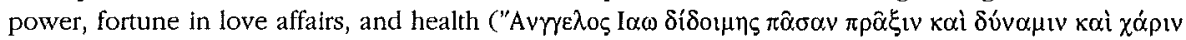

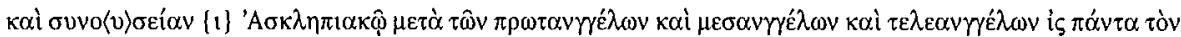

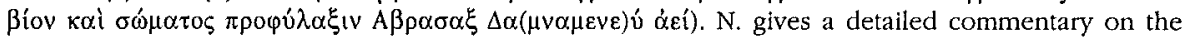
iconography and the text.

157) J. NEILs, Panathenaic Amphoras: Their Meaning, Makers, and Markets, in Goddess and Polis, p. 28-51: General presentation of the iconography, production, and inscriptions of the amphoras given as prizes in the Panathenaia.

158) G. NENCI, I decreti di Entella I-V, in ASNP, 21 (1991), p. 137-145: An autopsy of five of the decrees of Entella (EBGR 1989, 29), basically confirms the readings. N. presents the texts and photographs of the inscriptions.

159) G. NENCI, Florilegio epigrafico Segestano, in ASNP, 21 (1991), p. 920-929 [BE 1993, 718; $S E G 41,825,827$ ]: Ed. pr. of a dedication to the Diskouroi by the young and adult men of the gymnasium of Segesta (1, Hell.) and an inscription recording constructions in the gymnasium during the term of office of an hieromnemon (2, 4th/3rd cent.).

160) J. NOLLÉ - F. SCHINDLER, Die Inschriften von Selge (IGSK, 37), Bonn, 1991 [SEG 41, 1249-1252]: Corpus of the inscriptions and the testimonia of Selge in Pisidia; new texts are marked with an asterisk. The most interesting new text is an 'astragal-oracle' $(4, * 2 \mathrm{nd} / 3 \mathrm{rd}$. cent). It must have included 120 answers, but only five fragments survive. The correct answer was found by throwing the dice seven times. The names of Herakles, Nike Themis, Asklepios, Zeus, and the 
Dioskouroi head each answer, which is given in four hexametric verses; some of the verses are known from other 'astragal-oracles'. $N$. will present a detailed commentary in a forthcoming corpus of the alphabetic and astragal-oracles of Asia Minor. A group of texts concerns the prominent family of the Plancii Magniani, whose members held the most important priestly offices (15, 17-20). Dedications: to the emperors, Artemis, and the city (1, imp.), Athena (2, 1st/2nd cent.), and an anonymous deity (3*, imp.). Sacred officials: Priests of Artemis (1), Helios (84*), Athena (84*), a

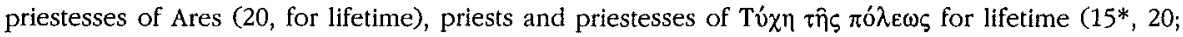
cf. 17), high priests and priestesses for the emperor cult in the city $\left(15^{*}, 16^{*}, 20\right)$, archierothytai $(17$, $20,57^{*}$ ) [on the office of hierothytes see infra $n^{\circ} 245$ ], a hierophantria of a mystery cult (15*), and agonothetai, usually members of the family of the Plancil Magniani, for lifetime $\left(15^{*}, 16^{*}, 20\right)$.

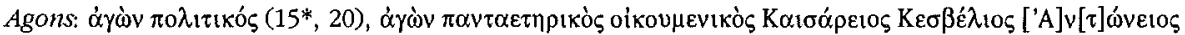

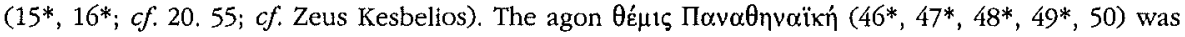
founded by Valeria Briseis for the memory of her sons Memnon, Hermolaos, and Kotyseus (ea. 3rd cent. AD); the only known contest was a stadion-race for boys and men; two men served as agonothetai. The agon Artemisios $\left(51^{*}, 52,53,54^{*}\right)$ was founded in the ea. 3rd cent. AD by $M$. Aurelius Memnonianus Tlepolemos and Aurelius Diogenianus Hermolaos $\left(54^{*}\right)$, in honour either of Artemis or of a woman with the name Artemisia; the agonothetes (and founder) Tlepolemos

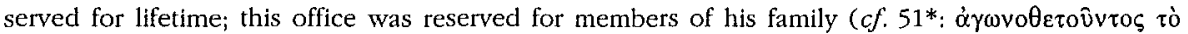

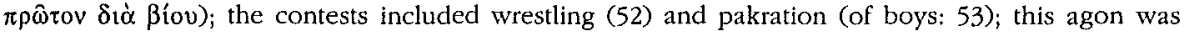
celebrated at least 8 times (53). Other agons (probably the agones politikoi) included contests in boxing of boys and men $\left(56^{*}, 57^{*}\right)$. An agonothetes of an unknown agon is mentioned in $n^{\circ} 82^{*}$. Other inscriptions commemorate the victories of a pankratiast in the Olympic games $\left(58^{*}\right)$ and victories of two other athletes in local agons $\left(59^{*}, 60^{*}\right) . \mathrm{N}^{\circ} 17$ mentions the temple of Ares (17) and a sanctuary of Tyche (Tychaion).

161) J. Nolí, Zur Geschichte der Stadt Etenna in Pisidien, in E. SCHwErTHEIM (ed.), Forscbungen in Pisidien (Asia Minor Studien, 6), p. 61-141 [BE 1993, 590; SEG 41, $1246,1247]$ : N. studies the history of Etenna, also focusing on the epigraphic and numismatic evidence for the cults of this city (Zeus, Hera, Demeter, Asklepios, Apollon, Nemesis, Helios, Tú $\chi \eta$ $\tau \hat{\imath} \varsigma$ $\pi$ ó $\lambda \varepsilon \omega \varsigma$, probably Herakles). He also presents a collection of the testimonia and the inscriptions of Etenna (new texts are marked with an asterisk). Seleukos (a Seleucid king or a local citizen) was honoured as ktistes (2, 1st cent. AD). Priests: High priests of the city emperor cult $\left(3,11^{*}, 12^{*}\right)$, a priestess for lifetime of Demeter $\kappa \alpha \tau \dot{\alpha} \pi \operatorname{co}_{\mathrm{Iv}}\left(4,3 \mathrm{rd}\right.$ cent. $\left.\mathrm{AD}, c f .5^{*}\right)$, a priest for lifetime of Dea Roma $\left(5^{*}, 2 \mathrm{nd} / 3 \mathrm{rd}\right.$ cent.). Also notice the rare word $\kappa \alpha$ v́ $\tau \alpha$ mentioned in a grave inscription; its meaning is not clear (18, 'urn', 'crematorium', 'grave'?) [probably 'urn']. In an introductory chapter (p. 78-86) N. discusses the methodological background for the use of coins as a source of information for (public) city cults, criticizing H. BRANDT's reconstruction of the cults of Aspendos [EBGR $1988,22]$.

162) E. Oustinoff, Marble Lamps, in Samotbrace, 7, p. 329-330: Ed. pr. of two marble lamps with the inscription @eŵv found in the Rotunda of Arsinoe in Samothrake (ea. 3rd. cent. BC).

163) O. PALAGIA, Cult and Allegory: The Life Story of Antemidoros of Perge, in Pbilolakon, p. 171-177 [BE 1994, 594]: P. studies the rock reliefs and the inscriptions of the sanctuary founded by Artemidoros of Perge on Thera (3rd cent. BC; IG XII 3, 421-422, and Suppl. 1333-1348). Traditionally, the relief representations of animals (eagle, lion, dolphin) were interpreted as symbols of gods (Zeus, Apollon, Poseidon). P. observes the analogy between these reliefs and representations on coins of certain cities: She interprets the laureate head as the head of Artemis Pergaia, the eagle as an emblem of Alexandria, the lion as a symbol of Miletos, the dolphin as that of Tenos. P. speculates that these cities marked important stages in Artemidoros' career in the service of the Ptolemies [but see the objections of F. GRAF, Bemerkungen zur buirgerlichen Religiositat im Zeitalter des Hellenismus, in M. WÖRRLE - P. ZANKER, Stadtbild und Bïrgerbild im Hellenismus, München, 1995, p. 107-109]. 
164) A. PARIENTE, Le monument argien des "sept contre Thèbes", in Polydipsion Argos, p. 195-225 [BE 1993, 29]: Ed. pr. of a boundary stone of a heroon dedicated to the cult

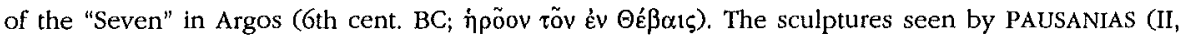
$20,5)$ must have stood in this heroon. P. suggests that the cult of the "Seven" was established in Argos in the middle of the 6th cent;; a cenotaph for the heroes fallen in Troy was built in the same time. After their victory at Oinoe (ca. 460) the Argives dedicated statues of the "Seven" and the Epigones at Delphi and renovated the heroon in Argos. P. discusses the political significance of these myths for Argos against the background of the wars against Sparta. [For the consequences of this new find for the interpretation of monuments in Argos and Delphi $c f$. M. DAUMAS, Argos et les Septs, in Polydipsion Argos, p. 253-264; J.-F. BOMMELAER, Monuments argiens de Delphes et d'Argos, in Polydipsion Argos, p. 265-3037.

165) A. PARIENTE, Chroniques des fouilles et découvertes archéologiques en Grèce en 1991, in BCH, 116 (1992), p. 833-954: The boundary stone of a sanctuary of Artemis was found in Myrina (Lesbos, p. 923). A lex sacra found in Kos contains a calendar of sacrifices to Apollon, the Dioskouroi, Artemis, Aphrodite, Zeus Polieus, Athena Polias, Hekate Soteira, and Leto (p. 931). An inscription on a vase names the hero Kerkaphos, to whom probably a sanctuary was dedicated at Trianda (Rhodes, 5th cent., p. 932).

166) C. PARISI PRESICCE, Panakeia, Iatros e le altre divinità asclepiadi a Cirene, in Africa Romana, 9, p. 147-166 [BE 1993, 698]: Study of the cult of Asklepios in Kyrene based on the archaeological and epigraphic evidence. One new inscription on an altar mentions the deity Panakeia (4th c. BC). The cults of Asklepios, Iatros, and Panakeja show some similarity with the respective cults in Kos; however, the further development of this cult in Kyrene was strongly influenced by the political situation in the city, i.e., by the aristocratic rule and later the democratic regime. [ES]

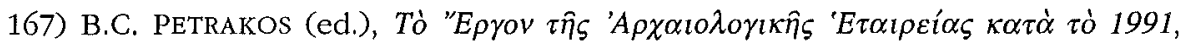
Athens, 1992: Report of the activities of the Archaeological Society at Athens with reference to new epigraphic finds in Rbamnous [infra $\mathrm{n}^{\circ} 169$ ], Epidauros (p. 11) [supra $\mathrm{n}^{\circ} 125$ ], Messene [infra $n^{\circ} 221$ ], Vergina [supra $n^{\circ} 5$ ], and Minoa on Amorgos [supra $\left.n^{\circ} 141\right]$.

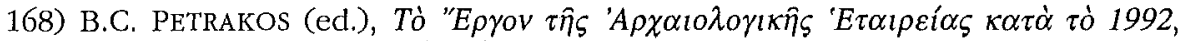
Athens, 1993 [SEG 41, 127, 361-363]: Report of the activities of the Archaeological Society at Athens with reference to new epigraphic finds. Rhamnous: A security horos mentioning an eranos. Messene: Dedications to Herakles and Hermes were found in the gymnasium (3rd-2nd/1st cent.).

169) B.C. PETRaKos, 'Av $\alpha \sigma \kappa \alpha \varphi \eta \dot{~ P \alpha \mu \nu o v v \tau o \zeta, ~ i n ~ P A A H, ~} 146$ (1991) [1994], p. 1-63 [SEG 41, 124]: $P$. presents 30 new inscriptions found in the fortress and the sanctuary of Nemesis at Rhamnous (p. 24-59), i.e., honorific decrees for Athenian officers in charge of the fortress (1-14, la. 4th cent.-la. 3rd cent.), dedicatory inscriptions (15-23, 6th-1st cent.), and grave inscriptions (27-30). The stele with the decree $n^{\circ} 1$ was to be erected in the sanctuary of Dionysos in Rhamnous. Several officers were honoured for the performance of the traditional sacrifices $(3,13,14)$; one text mentions the offering of $\pi \varepsilon \lambda \alpha$ voi to gods and heroes. The texts include dedications to Heros Archegetes $(15,17$; la. 6th-5th cent.) and Aphrodite (23, 4th/3rd cent.), a boundary stone of the iepò $\alpha \dot{v} \lambda \dot{n}$ of Heros Archegetes $(16,4 \mathrm{th} / 3 \mathrm{rd}$ cent.), and a list of eranistai $(24,1 \mathrm{st}$ cent.). The victors of torch races organized for the soldiers (19: Ptolemaia, 3rd cent.; 20-21: Diogeneia, 3rd-2nd cent.; $c f$. 23) dedicated torches to Zeus Soter and Athena Soteira.

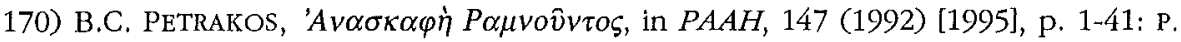
presents 11 new inscriptions from Rhamnous; one of them is a security horos mentioning an eranos (p. 38, no. 8, 4th cent.) $\left[=\right.$ supra $\left.^{\circ} 168\right]$.

*171) M. PETTERsson, Cults of Apollo at Sparta. The Hyakintbia, the Gymnopaidiai, and the Karneia (ActaAth, 12), Stockholm, 1992: P. argues that the three Spartan festivals of Apollon formed a ritual cycle related to the Spartan age system. Some epigraphic evidence is used in relation to the myth and worship of Hyakinthos in and outside Sparta but notice the absence of 
references to the cult of Artemis Hiakynthotrophos; $c f$. more recently $E B G R 1987,90$ ], the cult of Apollon Karneios and its distribution in the Dorian areas, and the Gymnopaidiai [for problems of method in P.'s study see the review by P. CARTLEDGE, in OpAth, 20 (1994), p. 287-290).

172) G. PETZL, Lukians Podagra und die Beichtinscbriften Kleinasiens, in Métis, 6 (1991), p. 131-145 [SEG 41, 1016, 1830]: A close analysis of LUKIAN's work Podagra shows that it reflects the same religious attitudes that are attested in the 'confession inscriptions' (sickness as punishment for sin, epiphany of the avenging deity, propitiation, manifestation of the divine power in the presence of a large crowd, praise of the power of the deity, belief in the healing power of the

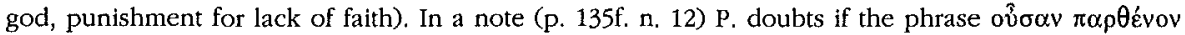

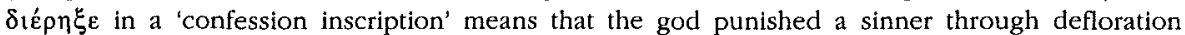
[EBGR 1990,53], since there is no evidence that sexual intercourse with the god was regarded as a punishment; on the contrary LUKIAN's treatise about the false prophet Alexandros (Alex. 42) implies that women proudly claimed to have had sexual intercourse with a god. P. contends that the sinner was punished by death. [For a similar interpretation: M. RiCL, The Appeal to Divine Justice in the Lydian Confession-Inscriptions, in E. SCHWERTHEIM (ed.), Forschungen in Lydien (Asla Minor Studien, 17), Bonn, 1995, p. 72 n. 13. However, P. overlooks the problem that the verb $\delta 1 \alpha \rho p \eta$ ivvut is not attested in the meaning 'to kill'; in P.'s example (DIO CHRYS., VIII, 32) the verb

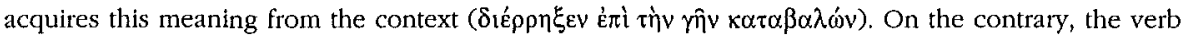
is well attested in the context of defloration, in medical literature. Besides, P.'s examples of women proud of having had sexual intercourse with a god concern married women, and not virgins. Finally, the 'confession inscriptions' indicate the death of the sinner always using clear und unequi-

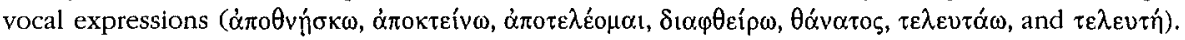
For the interpretation of this text, the starting point has to be the linguistic evidence, which quite clearly indicates what had happened to the virgin].

173) G. PETZL, Zum neupythagoreiscben Monument aus Pbiladelpheia, in EA, 20 (1992), p. 1-5 [BE 1994, 42, 43, 511]: P. discusses the grave monument of Pythagoras of Philadelpheia (ea. 1st. cent. AD), a follower of the Neopythagoreans. The relief has a symbolic representation of the crossroad which leads either to vice or to virtue; it indicates the two alternatives ( $\dot{\alpha} \rho \varepsilon \tau \eta^{\prime}, \dot{\alpha} \sigma \omega \tau(\alpha)$ and their consequences. The representation is framed by a grating in the form of $¥ ;$ in Neopythagorean thought, the letter $Y$ alluded to this crossroad. According to P.'s interpretation the personification of Arete gives the man, who has chosen the road of pain and virtue, a palm-branch, symbol of victory and honour; this honour will accompany the deceased to

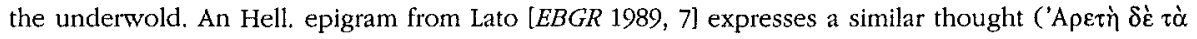

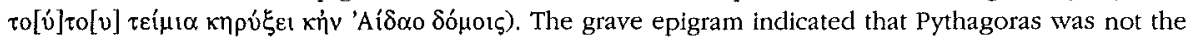
name given to the deceased at his birth, but a nickname which he won through his wisdom.

174) G. PETZL, Ein frühes Zeugnis filr den Hosios-Dikaios-Kult, in EA, 20 (1992), p. 143-146 [BE 1994, 484; SEG 41, 1060]: Ed. pr. of the grave inscription of Apollonios. A metrical funerary imprecation is addressed to Hosios kai Dikaios (near Hadrianoutherai, Mysia, 1st

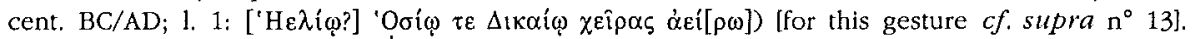

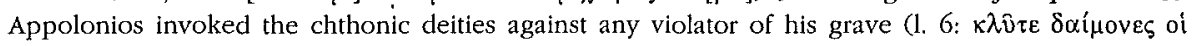

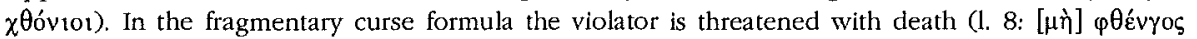

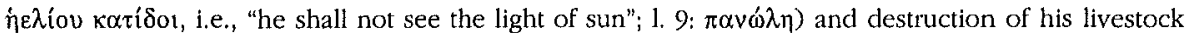

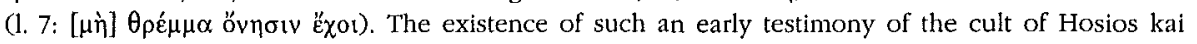
Dikaios in Mysia casts doubt on M. RICl's view [infra $\left.n^{\circ} 185\right]^{2}$ that the cult originated in the nortwestern part of Phrygia.

175) M. PIÉRART, Rapport sur les travaux de l'École Française d'Athènes en 1991. Argos. Agora, in BCH, 116 (1992), p. 673-676: A fragmentary honorific inscription for an emperor mentions Hera (Argos); her name was perhaps part of the title of a magistrate, e.g., a priest (p. 674). 
176) L. PIETILÄ-CASTRÉN, L. Mummius' Contributions to the Agonistic Life in the Mid Second Century BC, in Arctos, 25 (1991), p. 97-16 [SEG 41, 276, 286]: Collection of the epigraphic evidence for the activities of L. Mummius concerning agons in Greece. Mummius carried out constructions in the site of Isthmus and served as agonothetes of the Isthmia; he was honoured in Argos with the erection of his statue, possibly in connection with his arbitration between Argos and Kleonai over the organization of the Nemean games; in Eretria he was honoured with the organization of a race. $P$. rejects the view that this latter agon implies the establishment of a cult [but see EBGR 1991, 126; R.S. STROUD, in SEG 41, 276 points out that one of the texts used by $P$. was found in Aulis, and not in Nemea].

177) S.E. PORTER, Artemis Medeia Inscription Again, in ZPE, 93 (1992), p. 219-221: Reedition with new readings of the grave stele of 'Poseides the just', which contains funerary invocations of Artemis Medeia (Anahita?) and Artemis Ephesia (SEG 32, 1612; Asia Minor).

178) D.S. POTTER, The Inscriptions on the Bronze Herakles from Mesene: Vologeses IV's War with Rome and the Date of Tacitus' Annales, in ZPE, 88 (1991), p. 277-290 [BE 1992, 63; SEG 41, 1520]: Study of the historical evidence that can be extracted from the inscription on a statue of Herakles found in Seleukeia on the Tigris [EBGR 1990, 24, 39, 140] about the relations between Rome and the Parthians. P. comments on the temple of Apollon ( $\tau 0 \hat{v}$

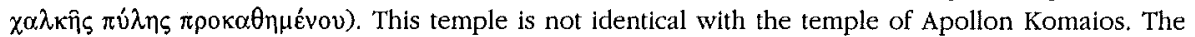
statue of Herakles (Nergal) was placed in this temple near the 'bronze gate' because of the apotropaic powers attributed to Herakles (protector of gates) and Apollon Propylaios. The statue of Apollon 'seated in front of the bronze gate' may be identified with the seated figure with kalathos and lyre depicted on coins of Seleukeia.

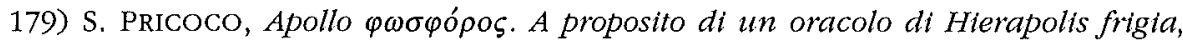
in Studi di filologia classica in onore di Giusto Monaco, Palermo, 1991, I, p. 491495 [BE 1993, 50; SEG 41, 1196]: The alphabetical oracle written in the temple of Apollon

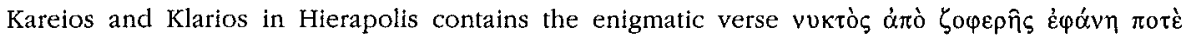

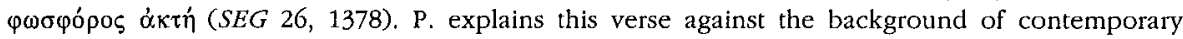
religious beliefs and practices in Asia Minor, i.e., the nocturnal divination in the sanctuary of Apollon Klarios (IAMBL., myst., III, 124), and the use of the adjective pwopópos as an attribute of

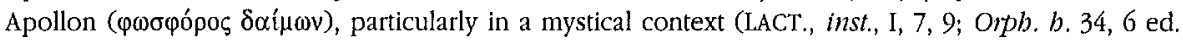
QUANDT). This oracle alludes to Apollon, the source of light, who guides man to security.

180) G. Pugliese Caratelli, Sul culto di Afrodite Euploia in Napoli, in PP, 47 (1992), p. 58-61: P. makes several critical remarks on E. MrRANDA's study on the cult of Euploia in Neapolis [EBGR 1989, 72]. There is no proof that the cult of Aphrodite Euploia was introduced in Knidos later than that of Aphrodite Doritis and Akraia, since PAUSANIAS (I, 1,3 ) does not refer to the date of the introduction of these cults, but only to the foundation of their sanctuaries. Euploea in STATIUS (Silvae 148-153) refers to a sanctuary of Euploia, and not to a place name. The introduction of Euploia's cult in Italy under Rhodian influence cannot be excluded.

181) F. QUEYREL, Les acclamations des inscriptions peintes du xyste, in Delphes, p. 333-348 [BE 1993, 277]: After a short introduction to the practice of acclamations for benefactors, agonothetai, contestants in competitions, kings, and emperors, in Hell. and imp. times, Q. gives a preliminary presentation of the dipinti found in the gymnasium at Delphi (imp.). The

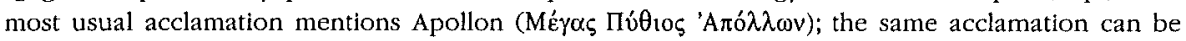
restored in inscriptions in honour of artists ( $F d D$ III 1, 226, 469). The Delphic acclamations are to be seen in the context of athletic and artistic contests and spectacles. Q. presents some parallels for acclamations underlining the greatness of a god, esp. in 'confession inscriptions' and narrations of miracles. [To Q.'s examples of acclamations add the acclamations of Aphrodisias (SEG 34, 10461065), Perge (SEG 34, 1306; EBGR 1991, 273), and Tralleis (SEG 38, 1172; EBGR 1988, 104); Q. overlooked the important article of T. KLAUSER, Akklamation, in RAC, 1 (1950), p. 216-233]. 
182) A. RAubitSCheK, Die Inschrift auf dem Apollon Béarn (I.G. V/2, 403), in Kotinos, p. 171 [SEG 41, 382]: The bronze statuette of Apollon from Lousol (ca. 470/60) made its appearance in the antiquities trade, so that the inscription (IG V.2, 403) could be studied again.

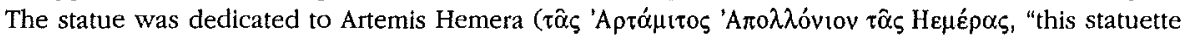
of Apollon belongs to Artemis Hemera"). [The reading 'A $S E G$ 41, 382].

183) J.R. REA, A New Bitbynian Month List, in ZPE, 90 (1992), p. 289-291: A recently published codex, perhaps part of a Latin-Greek glossary, of the 7th cent. A.D. (D. MONTSERRAT, in $B A S P, 27,1990$, p. 163-168) contains a list of Bithynian month names. The list may be reconstructed as follows: Dionysios, Herakleios, Dios, Bendidios, Stratios, Perites (Peritios or Prietios?), Areios, and Aphrodisios.

184) B. RÉmY - B. ÖZCAN, Trois inscriptions impériales grecques du musée de Tokat (Turquie), in EA, 19 (1992), p. 119-123: Ed. pr. of three inscriptions from Pontos, dedicated to Trajan (1), Hadrian (2), and Septemius Severus (3).

185) M. RICL, Hosios kai Dikaios. Seconde partie. Analyse, in EA, 19 (1992), p. 71 $102[B E 1993,546 ; S E G$ 41, 1836]: In the second part of her study on the cult of Hosios kai Dikaios [cf. EBGR 1991, 204] R. studies the diffusion of the cult (basically in Phrygia Epiktetos, but also in Galatia, in Lydia, and partly in other areas of Asia Minor), its nature, and iconography. Her study demonstrates the great diversity which characterizes the cuit. In Maionia the epithets Hosios and Dikaios are usually (with one exception) connected with the conjunction $\kappa \alpha i$ and designate one divinity. On the contrary, in Phrygia the conjuction $\alpha \alpha$ í is often omitted despite the fact that Hosios kai Dikaios were conceived as two distinct figures ( $c f$. the evidence from the sanctuary at Yaylababa Köyü). Some texts name only Hosios, whereas texts addressed only to Dikaios are extremely rare; this might reflect an earlier aspect of the cult. The neuter form of the name (Hosion kai Dikaion) is very rare. Hosios kai Dikaios present a distinct deity, and not a 'nom divin mystique' or an hypostasis of another deity (Apollon or Helios). R. also studies the combination of the notions of hosion and dikaion in the Greek literary tradition [one should add the oath of the hierai in the

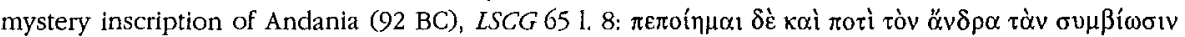

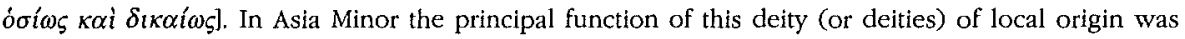
to remind the humans to respect the divine and secular laws. The iconography, influenced by the iconography of Nemesis and Dikaiosyne, sometimes presents Hosios kai Dikaios as one divinity and sometimes as a couple. The iconographical motives reflect the divinity's role as protector of animals, agriculture, and especially viniculture. In Maionia the god is often respresented as a rider, wearing a solar crown and holding a long palm branch; in Phrygia his usual attributes are the solar crown, a balance, and a staff, which reflect the weighing of souls and the administration of justice. Usually the dedications were made after a vow for the welfare of the dedicant, his/her family, and property; some monuments were dedicated by village communities. Two interesting exceptions are a funerary inscription with the appeal to Hosios kai Dikaios to punish persons who had wronged the deceased woman and one text closely related to the 'confession inscriptions'. In Maionia the cult was practiced in many small sanctuaries, the modest religious personnel consisting of priests, in one case of a prophetes; in Phrygia a major sanctuary is known at Yaylababa Köyü, where also

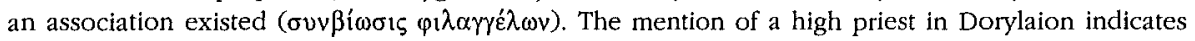
the existence of an hierarchy. Deities associated with the cult of Hosios kai Dikaios were Hosia, Hosia kai Dikaia, Apollon, Helios, Mes, Meter Theon (Kybele), and, sporadically, Dike, Zeus Hypsistos, Zeus Bronton, Zeus Olbios, Herakles, Chrysea Parthenos, Selene, Hermes, Dionysos, Dikaiosyne, Tyche, and Asklepios. The epigraphic evidence shows that Hosios kai Dikaios could be conceived either as angel(s) of a more distant god or as god(s) on their own right. The first conception is probably earlier. R. argues that the cult originated in Phrygia [but see supra $\mathrm{n}^{\circ} 174$ ] and was not influenced by Judaism.

186) M. RICL, Hosios kai Dikaios. Notuveaux monuments, in EA, 20 (1992), p. 95-100 [BE 1994, 559; SEG 41, 1241, 1242]: Ed. pr. of six new inscriptions related to the cult of Hosios kai Dikaios (Museums of 'Eski Sehir and Afyon). An altar with a relief representation of a Helios was 


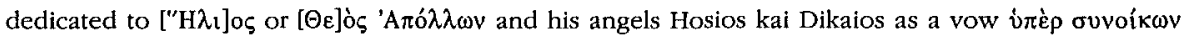
[members of the same oikos, i.e., perhaps a cult asociation] (1, Bozan, 2nd/3rd cent.). The dedicants

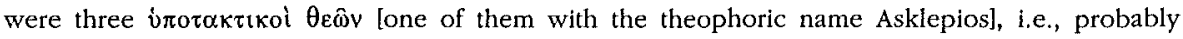
members of the cult personnel. This is the first unequivocal identification of Hosios kai Dikaios as angels of Apollon. Another altar was dedicated by a man to Helios, Hosios kai Dikaios for the welfare of his household and his village (2). In another dedication for the welfare of a household, Hosios kal Dikaios Theos is conceived as one deity and is representated wearing a solar crown (3, 2nd cent.). Another fragmentary dedication is addressed to Hosios Dikaios (4). Herakles is represented on one of the sides of an altar dedicated to Hosios; Hosios is represented holding a staff; Herakles' association with Hosios kai Dikaios is well attested (5). A dedicatory tablet is addressed to Hosios (6, 2nd/3rd cent.).

187) J. ROBERT - L. ROBERT, Décret de Colophon pour un chresmologue de Smyrne appelé à diriger l'oracle de Claros, in BCH, 116 (1992), p. 279-291 [BE 1993, 456]: Ed. pr. of an important honorific decree of Kolophon (2nd cent. BC) for the chresmologos

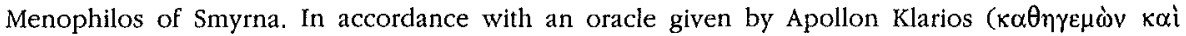

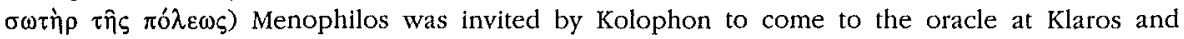

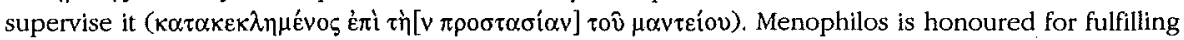
his duties as $\dot{\pi} \pi 0 \varphi \eta$ ins ("interprète des choses divines", p. 283-287) in a way worthy to the oracle's fame. The honours were to be announced at the festivals Dionysia and Great Klaria. The stele was

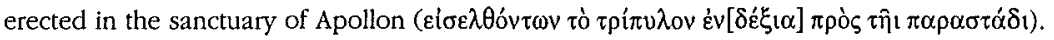

*188) N. ROBERTSON, Festivals and Legends: The Formation of Greek Cities in the Light of Public Ritual (Phoenix, Suppl. 31), Toronto-Buffalo-London, 1992: Making extensive use of the epigraphic evidence, R. studies the way old Greek festivals reflect early forms of public organization and warfare. He argues that each of the three Athenian festivals of the month Hekatombaion had served in its turn as the chief new year's festival in different periods of Athenian history. The Hekatombaia, a festival of Apollo in which the youth was introduced to the citizen body, is a relic of the days when Athens was a small community southeast of the Akropolis; the Synoikia arose when Attika was organized in phratries; the Panathenaia were introduced by Peisistratos, who placed the phratries under some constraint, in order to display the unitary strength of Athens. The Oschophoria and the Olympieia are interpreted against the background of Athens' concern with seafaring and cavalry respectively. $R$. also studies the Spartan Gymnopaidiai as a festival related to the enrollment of citizens. He suggests that three early agonistic festivals (Parparonia, a festival near Kenchreai, and Ithomaia) and the sacrifice at Phigaleia were later associated with the wars of the Argives and the Messenians against Sparta. [R.'s analysis is stimulating, but the result too hypothetical, due to the late and often equivocal source material. To mention only one example, the two epigraphic testimonia for the festival Parparonia discussed in

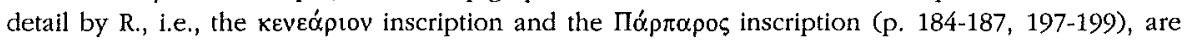
objects of great controversy with regard both to their reading and to their interpretation; see more recently $E B G R$ 1989, 92; 1990, 85; SEG 41, 295. For the Athenian festivals related to the myths of Theseus R. could not consult C. CALAME, Thésée et l'imaginaire atbénien, Lausanne, 1990].

189) G. ROGERS, The Constructions of Women at Ephesos, in $Z P E, 90$ (1992), p. 215$223[B E 1993,71]$ : R. studies the contribution of women benefactors for the repair or construction of buildings in Ephesos in imperial times. Until the 3rd cent. AD they usually appear in inscriptions recording the construction, dedication, or restoration of buildings as the wives and daughters of male benefactors. Numerous texts from the first four centuries AD attest constructions funded by priestesses, who either drew upon family wealth to fulfill the obligations of their office or spent their own funds. From the middle of the 3 rd cent. women were represented as builders in their own right. This increasingly prominent rôle of wealthy women in public life can be seen also, e.g., in their service as prytaneis, gymnasiarchs, Asiarchs, or theoroi to the Olympic games.

190) D. ROUSSET, Review of C. ANTONETTI, Les Étoliens, image et religion, Paris, 1990, in RPh, 66 (1992), p. 377-379: R. corrects A.'s view that the epithet Apollon Thermios is attested only from the late 3 rd cent. BC (see ISE 78, 247/6). This epiphet may be attested already 
as early as the 5th cent. (IG IX $1^{2}$ 91: ӨPEMION, with a metathesis). [The ethnic name Opépı / $\Theta \varepsilon ́ p \mu$ to is not necessarily a divine epithetl.

191) G. RouX, The History of the Rotunda of Arsinoe, in Samotbrace, 7, p. 231-239 [BE 1993, 69]: The name of the husband of Queen Arsinoe in her dedicatory inscription to the Dioskouroi (Samothrace, 2.1, $\mathrm{n}^{\circ} 10$ ) is not preserved. R. restores the name of Ptolemy II (not Lysimachos); consequently Arsinoes' Rotunda was dedicated ca. 276-270 BC. This is the only dedication of a Hell. queen alone, without the king. This can be explained in view of Arsinoes' adventurous life; with the dedication of the Rotunda she expressed her gratitude to the Diskouroi for saving her life and helping her become queen of Egypt.

192) C. Russo, Sul v. 9 della laminetta orfica di Hipponion, in $P P, 47$ (1992), p. 181$182[B E 1993,25 ; 1994,55]$ : In 1.9 of the Orphic text from Hipponion R. suggests the reading

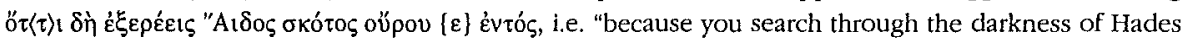
inside (its) confines" (ONOEENTOE, on the gold leaf) [for other restorations see EBGR 1989, 109; 1991, 153]. The proposed restoration corresponds to the idea that the path which the initiate will take with the other mysts begins in the kingdom of Hades.

193) G. SACCO, Alcune iscrizioni greche d'Italia, in $M G R, 16$ (1991), p. 217-224: Ed. pr.

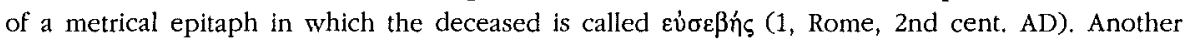

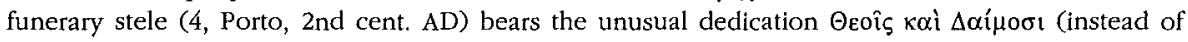

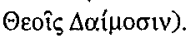

194) F. Salviat, Calendrier de Paros et calendrier de Tbasos. Boédromion, Badromia et la solidarité des arms, in Mélanges Lévêque, 6, p. 261-267: s. attempts a reconstruction of the calendars of Paros and its colony Thasos, based on the epigraphic evidence (esp. LSS 69, Thasos, 4th cent. BC). According to $S$. the calendar of Thasos had the following months (agreements with the calendar of Paros are marked with an asterisk): 1. *Apatourion, 2. Maimakterion, 3. *Posideon, 4. *Anthesterion, 5. Galaxion, 6. *Artemision, 7. *Thargelion, 8. *Plynterion, 9. Hekatombaion, 12, *Badromion. The calendar of the two Ionian cities has a strong similarity to that of Athens.

195) F. SALVIAT, Sur la religion de Marseille grecque, in Marseille grecque, p. 141150: Overview of the various cults attested in Massalia (Artemis Ephesia, Apollon Delphinios, Apollon Thragelios, Dionysos, Leukothea, Kybele) and the local festivals (Anthesteria, Thargelia, Apatouria). The religious calendar of Massalia presents a close similarity to those of Lampsakos and Phokaia.

196) D. SANSONE, Cleobis and Biton in Delphi, in Nikephoros, 4 (1991) [1992], p. 121132 [BE 1993, 91; SEG 41, 521]: The inscription on the statues of Kleobis and Biton in Delphi has been read in various ways by P. FAURE and C. VATIN. Even if the reading of the name of the Dioskouroi should be correct (Fovókov, "of the Anaktes"), it means that the statues were dedicated to the Dioskouroi, not that they represented the Dioskouroi.

197) R.-A. Santiago Alvarez, Sobre las "Teiorum dirae", in Faventia, 12/13 (1990/1991), p. 327-352: S. studies the similarities (in content and in formulaic expressions) between the old and new fragments of the imprecations of Teos $(S E G 31,985)$ [cf. EBGR 1991, 91 and supra $\mathrm{n}^{\circ}$ 86]. [ES]

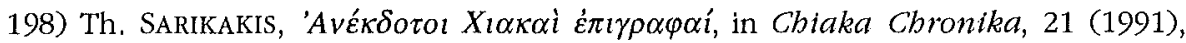
p. 13-21: Ed. pr. of 17 inscriptions, including a dedication to a Heros and the Gerousia (Chios, imp., 9); S. interprets the text $\mathrm{n}^{\circ} 17 \Delta$ pókıо $\Sigma \varphi \eta \dot{\tau} \tau \omega$ as a dedication of a woman to the Athenian eponymous hero Sphettos.

199) F. SARTORI, Ancora sulle dediche a Demetra in Eraclea Lucana, in Mélanges Lévêque, 6, p. 269-277: After a critical examination of the interpretations proposed for the graffiti on sherds and lead tablets found in the sanctuary of Demeter in Herakleia (SEG 30, 11501170 ), i.e., as dedications of statuettes of the dedicants to Demeter or as sacred manumissions, 
S. endorses G. MANDOLI's view (Manomissione sacre in Eraclea Lucana, in PP, 41, 1986, p. 99-107) that these texts record manumissions in the form of a dedication to the deity; other interpretations, however, cannot be excluded, e.g., dedications by people seeking the protection of the goddess.

200) M.H. SAYAR, Der thrakische König Mostis, in Tyche, 7 (1992), p. 187-195 [BE 1993, 99]: Ed. pr. of a dedicatory inscription (Heraion Teichos, Propontis, 2nd/1st cent.). An agoranomos dedicated a statue of Hermes Agoraios for the welfare of King Mostis and the demos of the Heraitai.

*201) P. SCHMITT PANTEL, La cité au banquet. Histoire des repas publiques dans les cités grecques, Rome, 1992 [BE 1993, 169]: S.'s impressive work on the history of public banquets in the Greek cities, from the archaic to the Roman period, contains many significant contributions to apects of public cult, esp. to the rôle of banquets in festivals. S. makes ample use of the epigraphic evidence, esp. of the lex sacra of the Labyadai in Delphi (CID 9, p. 81-93) and the Hell. inscriptions concerning religious festivals and the contributions of benefactors (p.255-420; for a list of inscriptions see p. 527-544). I indicate briefly some of the subjects of religious significance discussed in her book: participation in banquets after a sacrifice and its rôle for the construction of identity (p. 45-52), banquet and the initiation of the youth (p. 76-81), various festivals (Atbens, Apatouria: p. 81-91, 131-135; Panathenaia: p. 126-130; Dionysia: p. 130f.; Thesmophoria: p. 131-135; Theseia: p. 136-139; Bouphonia: p. 139-143; Delphi, Apellai: p. 81-91), the vocabulary of banquets used in the inscriptions (p. 261-289), and the public banquets, usually funded by benefactors, in Hell. festivals (organization, participation, funding, location, food and wine, distributions, p. 291420). [For a critical review of the part dedicated to euergetism see Ph. GAUTHIER, in $B E 1993,169$, who comments on several inscriptions and points to a methodological problem of the book. The public banquets are mainly known from 2nd cent. BC inscriptions, whose focus on the rôle of benefactors may be misleading, esp. with regard to the participation of non-citizens. Many festivals, however, for which we have no Hell. regulations and which continued to be celebrated according to the old traditions, were probably limited to the citizensl.

202) J. SCHWARTz, Décrets de prêtres sous Ptolémée III Evergète, in ZPE, 91 (1992), p. 83-84 [BE 1993, 677]: A fragment of a drecree of the synod of priests found in Elephantine [now in Louvre; see supra $n^{\circ} 13,23$ ] and a fragment now in Uppsala $(S B$ 10036) belong to the same decree. S. publishes the fragment of Uppsala with commentary ffor the decrees of synods of Egyptian priests for Ptolemies see EBGR 1991, 104].

203) E. SCHWERTHEIM, Neue Inschriften aus Adramyttion, in $E A, 19$ (1992), p. 125-133 [BE 1993, 44, 435]: Ed. pr. of a honorific inscription for the benefactor Alkippides by the demos of Adramyttion and the Roman merchants (late 1st cent. BC); Alkippides received heroic honours (1. 6: й $\rho \omega \alpha)$.

204) H.A. SHAPIRO, Mousikoi Agones: Music and Poetry at the Panathenaia, in Goddess and Polis, p. 52-75: Based on the iconographic evidence S. argues that Perikles did not introduce or reintroduce the musical contests at the Panathenaia, but reorganized them, adding certain events, dropping others, and enacting the new program as law. $I G \mathrm{II}^{2} 2311$ (early 4th cent.), which lists contests of kitharodoi, aulodoi, men kitharistai, and auletai, probably also boys kitharistai and aulodoi, reflects the program laid down by Perikles. A close analysis of the iconography of archaic vases shows that the earlier program included contests of auletai and aulodoi (probably from 566 on, under the influence of the Pythia); contests of kitharodoi and kitharistai were added later, still in the 6th cent. Contests of rhapsodes had probably taken place before Hipparchos limited this contest to perfomances of the Iliad and the Odyssey.

205) P.J. SIJPESTEIJN, A Remark on SB V 7905, in CE, 134 (1992), p 328: s. interprets the dedication to Zeus Soter by Besarion. According to the metrical text the god saved Besarion, a messenger of the prefect (not Besarion and a messenger of the prefect, as understood by $\mathrm{E}$. BERNAND (supra $\mathrm{n}^{\circ} 13$, text 30 ). 
*206) S.J. SimON, The Function of Priestesses in Greek Society, in The Classical Bulletin, 67 (1991), p. 9-13: Overview of the requirements, ritual and administrative duties, remuneration, and honours of priestesses in the Greek cities, basically in the light of the epigraphic evidence.

207) K.W. SLANE, Corinth. Volume XVIII, Part ii. The Sanctuary of Demeter and Kore. The Roman Pottery and Lamps, Princeton, 1990 [SEG 40, 305]: A basin found in the sanctuary of Demeter in Korinth bears a graffito on the underside (p. $122 \mathrm{n}^{\circ} 265$ ). [The editors of $S E G 40,305$ suggest the reading 'A $\theta \mathrm{v} v \hat{\alpha}]$.

208) J. SLIWA, Egyptian Scarabs and Magical Gems from the Collection of Constantine Scbmidt-Ciazynski, Warszawa, 1989 [SEG 40, 1659]: Ed. pr. of magical gems in a private collection; I mention some interesting pieces (2nd-3rd cent): Representation of Isis and Harpokrates and the text ABP/AKA/THI (51); representation of Isis-Fortuna and the name of the

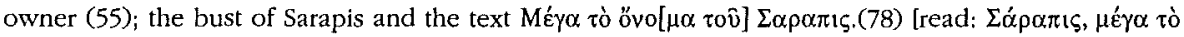

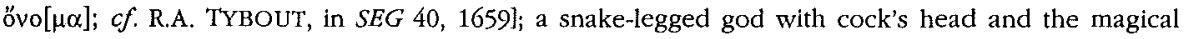

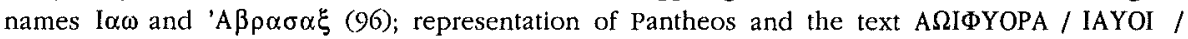

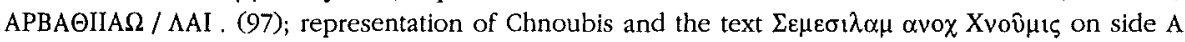

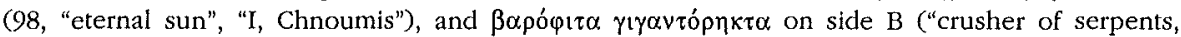
breaker of giants"); the gem may have been a medical amulet (98); representation of Chnoumis

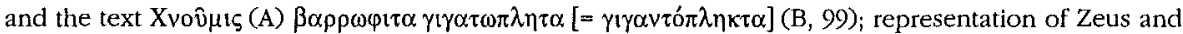

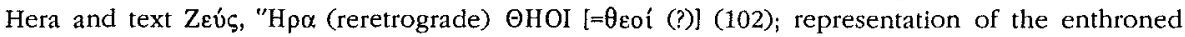

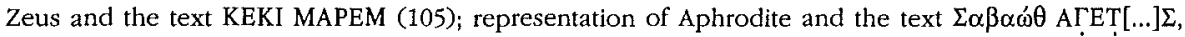
$\left.P \alpha \beta \rho \imath^{\prime} \lambda \lambda\left[=\Gamma \alpha \beta \rho เ \eta^{\prime} \lambda\right)\right](106)$; the text I $\alpha \dot{\omega}^{\prime} A \beta \rho \alpha \chi \alpha$ (108); representation of Herakles seated on a rock

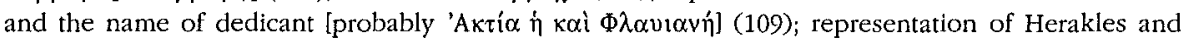
the texts $I \Omega H(A)$ and $H \Omega Y O I(B, 110)$; representation of Helios-Harpokrates and the text I $\alpha \omega, \alpha 1 \psi \omega \omega$,

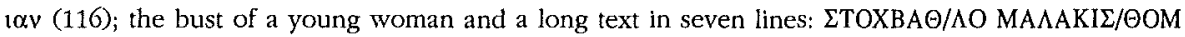

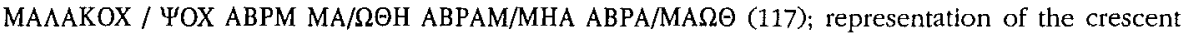

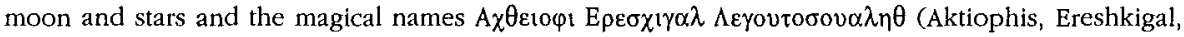
Neboutosualeth, 119); representation of Apollon and Daphne and the text $\Omega Y O A \Omega O$ OYEI ПYPऽOПAI (148).

209) H. SOlin, Review of J. REYNOLDS - R. TANNENBAUM, Jews and Godfearers at Apbrodisias, Cambridge, 1987, in Arctos, 25 (1991), p. 207-208 [BE 1993, 508; SEG 41, 918]: Short discussion of the term $\theta \varepsilon \circ \sigma \varepsilon \beta \varepsilon i \xi$, which in the inscription concerning the Jewish community of Aphrodisias ( $S E G$ 36, 970; $E B G R$ 1987, 95) denotes the gentiles, but in the epigraphic record, in general, can have a variety of meanings (Jews, converts, sympathizers of the Jewish religion).

210) L. SOVERINI, Il "commercio nel tempio": Osservazioni sul regolamento dei

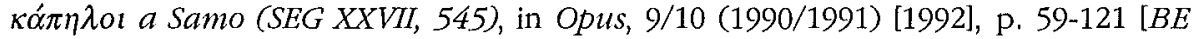
1993, 393]: S. reedits with ample commentary the Hell. inscription of Samos which regulates the operation of shops in the Heraion (SEG 27, 545). S. focuses on the economic and legal aspects of the document, giving numerous parallels for the operation of shops in sanctuaries, the presence of soldiers (esp. in periods of war), the exclusion of slaves from financial activities in the sanctuary, and prohibitions against fugitive slaves and suppliants.

211) A.J.S. SPAWFORTH, Spartan Cults under the Roman Empire, in Pbilolakon, p. 227-238: S. studies the various aspects of worship in Roman Sparta, esp. the administration of public cults by the hieromnemones and the hierothytai [on this office see $\operatorname{lnfra~} \mathrm{n}^{\circ} 243$ ], the civic priesthoods, the public divination, the religious innovations (esp. the introduction of the emperor cult and the establishment of a Serapeum), and the private cult-practices (esp. dedications). This material "underlines the extent to which civic religion played a major part in evoking the old Sparta which the Roman city was so intent in placing on show". 
212) A. STEINER, Pottery and Cult in Corintb: Oil and Water at the Sacred Spring, in Hesperia, 61 (1992), p. 385-408: S. studies a group of oil-containing vessels found at the sanctuary called 'the Sacred Spring' in the agora of classical Korinth (5th-2nd cent. BC). They were probably used in a chthonic cult. $\mathrm{S}$. collects evidence from leges sacrae for the use of oil in the cult (p. $402 \mathrm{n}, 70$ ).

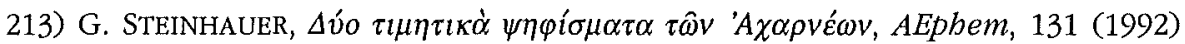
[1993], p. 179-193: Ed. pr. of two honorific decrees of the demos of the Acharneis for its officials

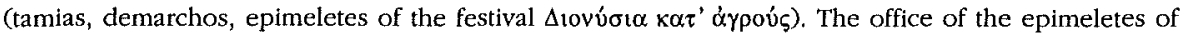
the Dionysia in a demos is attested for the first time. Besides their other duties they offered sacrifices to the gods and heroes, conducted the Dionysia (sacrifice, procession, agon), and dedicated a phiale. The decrees were set up in the sanctuary of Athena Hippia (Athens, 315/4). The officials, in the second decree, and their descendants were given the privilege of prohedria at the Dionysia in Acharnai. The tamias was liable to control of the city authorities, probably because he administered public (Athenian) money for the Dionysia. It is possible that Demetrios of Phaleron (316/5) legislated that the Dionysia celebrated in the demes were to by financed by the city.

214) Frank Stemberg AG, Auktion XXV, 25. und 26. November 1991. Antike Münzen. Renaissance Medaillen. Geschnittene Steine und Scbmuck der Antike. Antike Bronzen, Zürich, 1991 [SEG 41, 1713-1720]: The catalogue includes eight gnostic gems with representations of deities and magical figures (Hekate: 871; Herakles: 865; Hermes: 869; Abrasax: $867,871,872$; Chnoubis: 870 ; Chnoubis-snake: 873 ; a scorpion: 868 ) and inscribed with magical names and words: HHH (865), I $\alpha \omega$ (867, 872), $\Omega$ I $\Theta M E / N X I N I \Delta / M B \Omega(868), A \beta \lambda \alpha \theta \alpha v \alpha \lambda \beta \alpha$

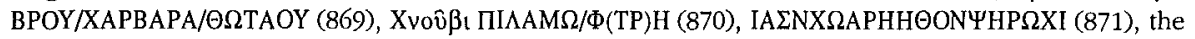

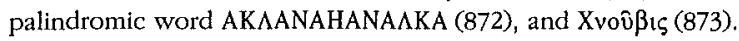

215) Frank Sternberg AG, Auktionskatalog Nr. 4, Juli-August 1992. Münzen und Medaillen. Geschnittene Steine der Antike. Schmuck und Kleinkunst der Antike, Zürich, 1992: The catalogue includes a gnostic gem with a representation of the Chnoubis-snake and the inscription $X v 0 u \hat{\beta} 15$ (525) and a bronze seal in the form of a tabula ansata with a dedicatory

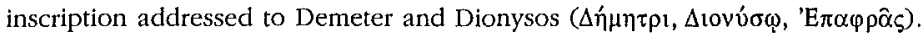

216) Frank Sternberg AG, Auktion XXVI, 16. November 1992. Antike Minzen. Geschnittene Steine und Schmuck der Antike. Antike Kleinkunst, Zürich, 1992: The catalogue includes two inscribed gnostic gems (576: representation of the Chnoubis-snake and the inscription Xvoûus; 577: with a long inscription) [The first five lines are probably pseudo-letters;

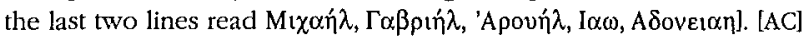

217) A. Stramaglia, Il leone, il tesoro e l'indovinello, in ZPE, 91 (1992), p. 53-59: One of the miracles narrated in the Epidaurian collection of healing miracles $\left(\mathrm{n}^{\circ} 46\right.$ ed. HERzOG) reports how a woman found a lost treasure on the spot where the statue of a lion cast its shadow at noon, in the month Thargelion. This is a folklore motive, probably also applied by IAMBLICHOS in his Babyloniaka.

218) J.H.M. STRUBBE, Grave inscriptions from Pessinus, Galatia, in EA, 19 (1992), p. 33-43 [BE 1993, 581]: S. restores several grave inscriptions from Pessinous with fines ( $4=S E G$ 31,

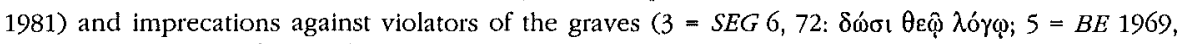

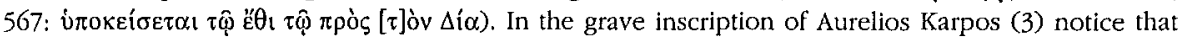
he had erected an altar in the middle of the grave.

219) G.J. SZEMLER - N.C. WILKIE, Two Inscriptions from West Lokris and Doris, in

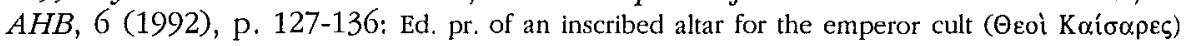
dedicated by the local tagoi (Pyrgos, Doris, late 2nd c. AD?).

220) H. TAEuBER, Eine Priesterin der Perasia in Mopsubestia, in EA, 19 (1992), p. 19$24[B E$ 1993, 604; 1994, 226]: Ed. pr. of the grave altar of Eutychia from Mopsuhestia (Kilikia, 2nd/3rd cent.) [ $c f$. the preliminary report: $E B G R$ 1990, 281]. Eutychia was priestess of the Anatolian

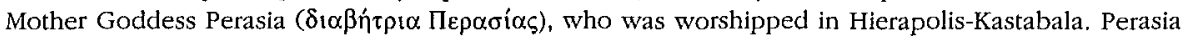


was associated with Artemis, Hekate, Selene, Demeter, and Aphrodite (IGR III 903). The title of Eutychia $(\delta 1 \alpha \beta \eta \dot{\eta} \tau, \alpha)$ is related to the ritual of walking on burning coals (STRAB, XII, 2, 7: $\delta \imath^{\text {' }}$ $\dot{\alpha} v \theta \rho \alpha k i \hat{\alpha}, \zeta \beta \alpha \delta i \zeta_{E \imath}(v), T$, gives a detailed commentary on fire-walking in Perasia's cult. Eutychia's agnomen Metereine (from Meter?) may be related to her office as priestess of Artemis. The name Metereine was already attested in Mopsuhestia.

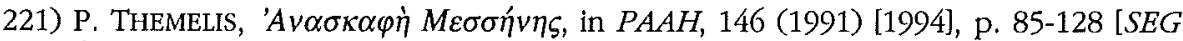
41, 365]: Presentation of new epigraphic finds from the sanctuary of Artemis Ortheia in Messene, including the dedication of an agonothetes to Artemis Ortheia (p. 90,3rd cent), dedications to the gods (p. 91, 2nd cent.?), and to Artemis (p. 97f., $\mathrm{n}^{o s}$ 2-3, 2nd/1st cent.). Notice also the treaty oath preserved in a fragment of a treaty between Messene and Polyperchon (317 BC, p. 96f., $n^{\circ} 1,1.9-11$ )

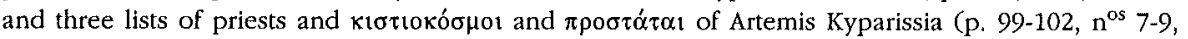
3rd cent.) [cf. EBGR 1991, 233]. One intact list names 28 kistiokosmoi.

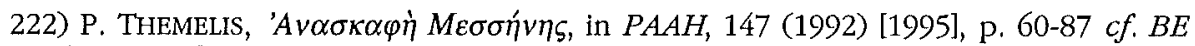
1994, 93, 125]: T. presents numerous new epigraphic finds in Messene. Five dedicatory inscriptions found in the gymnasium were addressed to Herakles and Hermes (3rd-1st cent., p. 63-69). A dedication to Apollon Agyieus was found near the fountain called Arsinoe (p. 84, 4th/3rd cent.), whose sanctuary has to be located on the north side of the agora (cf. IG V 1, 1441).

223) M. TORTORELli GHIDONI, Sul $v .4$ della laminetta di Hipponion: YYXONTAI o IYXOYNTAI?, in PP, 47 (1992), p. 177-181 [BE 1993, 25; 1994, 54]: T. proposes a new

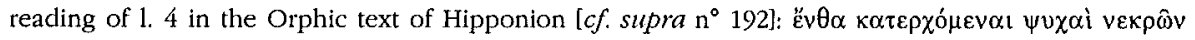

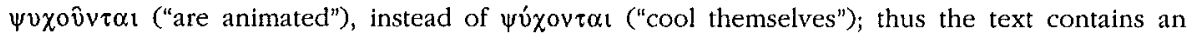
eschatological message, i.e., the souls of the just receive new life.

224) J. Tréheux, L'unité de pesée et l'unité de compte des biéropes à Délos, in Economics of Cult, p. 21-23: The Attic drachma remained the unit of measurement in the accounts of the hieropoioi of Delos even after the island gained its independence (314 BC).

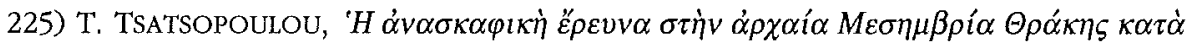
tò 1989, in $A E M T, 3$, p. 577-585: Ca. 200 inscribed sherds were found inside the temple of Apollon in Mesembria and near it (6th/5th cent); most of them are inscribed with the the name of Apollon, which was probably pronounced 'Ampollon'.

226) O. Tzachou-AleXandri, $A$ Vase Painter as Dedicator on the Atbenian Acropolis: A New View of the Painter of Acropolis 606, in D. BUITRON-OLIVER (ed.), New Perspectives in Early Greek Art, Hannover-London, 1991: T.-A. publishes a new amphora painted by the Painter of Akropolis 606. Based on the epigraphic evidence for vases dedicated by their painters to Athena she argues that the masterpiece of this painter, found on the Akropolis, was a dedication by the artist himself (ca. $565 \mathrm{BC}$ ).

227) V. TZAFERIS, The "God who is in Dan" and the Cult of Pan at Banias, in Eretz Israel, 23 (1992), p. 128-135: T. studies two aspects of syncretism and cult continuity in Palestine, i.e., the continuous worship of a local deity called $\theta$ cò $\zeta \dot{~} \dot{\varepsilon} v \Delta \alpha v o \hat{\zeta} \zeta$ until the late imperial period (Banias) and the introduction of the cult of Pan (later called Diopan) in Banias and Caesarea Philippi.

228) Ch. Tzouvara-Souli, 'A $\mu \beta \rho \alpha x i \alpha$, Arta, 1992 [BE 1993, 342]: General presentation of the history and topography of Ambrakia, with thorough discussion of the various cults attested in this city (p. 133-201), i.e., the cults of Aphrodite Aineias, Apollon (Agyieus, Pythios), Athena Chalinitis, Artemis (Agrotera, Hegemone, Pergaia, Pasikrata), Asklepios, Dione, Hestia, the Nymphs, Zeus (Prytanis), and the Egyptian dieties. The cults of Apollon, Athena, and Artemis were strongly influenced by Ambrakia's mother city, Korinth. [B. HELLY, in $B E$ 1993, 342 remarks that one of the inscriptions is a dedication to (Apollon) Soter and Zeus (not Zeus Soter)]. 
*229) F. VAN STRATEN, Votives and Votaries in Greek Sanctuaries, in Le sanctuaire grec, p. 247-284: S. gives an excellent overview of the various aspects of dedications in Greek sanctuaries. The ancient iconography (dedicatory reliefs) shows that worshippers regarded votives as a typical component of a sanctuary. The vocabulary attested in the inscriptions reflects the views of ancient worshippers about dedications, as decorative elements ( $\alpha$ ' $\gamma \alpha \lambda \mu \alpha$, kó $\sigma \mu \varsigma)$ and commemorations of events ( $\mu v \eta \mu o ́ \sigma v v o v)$. In general, dedications established a permanent link between the worshipper and the deity. The leges sacrae both regulate the placing of dedications (LSS 107, 123; LSCG 43) and introduce measures for their protection (LSAM 74). A comparison between the iconography and the inscriptions reveal an interesting aspect of dedications by women. Although some inscriptions indicate that a woman alone was the dedicant, the relief representation presents the dedication as a family affair; on the contrary, private dedications by men could be regarded as a private matter. The iconography of votive reliefs is rather limited, focusing on the elements of incubation, prayer, sacrifice, and, rarely, ritual dances. The sacrifice scenes on reliefs depict only the presentation of the animal to the altar or the placing of the oulat on the altar, and not the actual killing of the animal.

230) E. VARINLIOGLU - A. BRESSON - P. BRUN - P. DEBORD - R. DESAT, Ouranion en Carie, in REA, 94 (1992), p. 155-174 [BE 1993, 519]: Ed. pr. of two Hell. honorific decrees of Ouranion which attest the eponymous official stephanephoros $(1,2)$ and the month Eleutherion (1). One of the decrees was to be inscribed in a sanctuary, probably that of Aphrodite (1). The goddess with the epithet Akraia (I.Keramos 10) should be identified with Aphrodite, and not Hera (p. 171).

231) A. Vegas SANSALVADOR, X $\alpha \mu v v v \eta$ ein Beiname der Demeter in Olympia, in Glotta, 70 (1992), p. 166-180 [cf. SEG 41, 395]: Linguistic study of the epithet Chamyne, attested for Demeter in Olympia (PAUS. VI, 20, 8-9; VI, 21, 1; IVO 485) [cf. EBGR 1991, 259]. The evidence for the association of Demeter Chamyne with the Eleusinian goddesses, her relation to horses, the related cult of Demeter Konia (from xóvis, 'dust'), and the myth of Demeter's sacred marriage with Iasion, one of the Daktyloi related to the $\chi \alpha \mu \varepsilon \hat{v} \alpha_{\alpha}$, support the conclusion that Demeter Chamyne was a chthonic deity; her epithet is probably related to $\chi \alpha \mu \alpha i$ and evivń, i.e., 'having her lair on the earth' [cf. already O. KERN, Die Religion der Griecben, Berlin, 1926, I,

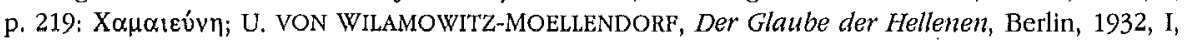
p. 207 n. 1].

232) M. DE Henar Velasco Lopez, Le vin, la mort et les bienbeureux. Á propos des

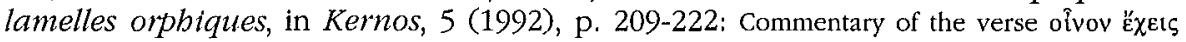
$\varepsilon \dot{v} \delta\langle\alpha\rangle\langle\mu o v \alpha \tau i \mu\langle\hat{i}\rangle \nu$ in the Orphic texts from Pelinna (Thessaly) (for the text see most recently $E B G R$ 1991, 89; for this verse $c f . E B G R$ 1990, 91]. The wine is characterized as "a fortunate recompense' [for an alternative reading ("you have received, fortunate, wine as your honour", see $E B G R$ 1991, 89]. $V$. argues that the reference to wine should not be interpreted as a reference to funerary libations or the initiation ritual, but to the deceased person's life after death; this view can be supported by many literary sources which describe the pleasures of the underworld as a banquet with an abundance of wine.

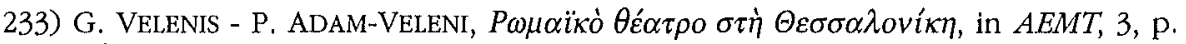
241-256 [BE 1992, 313]: V.-A. report the discovery of a huge building (length $250 \mathrm{~m}$., 1st-4th cent. $A D)$, probably the theatre/stadium mentioned by Byzantine authors. They present a list of archaeological and epigraphic monuments related to performances in this theatre, including an unpublished funerary monument for a winner of a contest.

*234) H.S. VERSNEL, Insconsistencies in Greek and Roman Religion. I. Ter Unus. Isis, Dionysos, Hermes: Three Studies in Henotbeism, Leiden, 1990: The three studies are devoted to the cult of Isis in the Hell. period (p. 39-95, with detailed commentary on the aretalogy of Maroneia), the cult of Dionysos in Athens (p. 96-205, with presentation of the epigraphic evidence at p. 137-146), and an epigram of Martialis $(V, 24)$ for the gladiator Hermes, which resembles an aretalogy (p. 206-251). But besides these studies, this important book contains 
stimulating remarks on a variety of subjects, with extensive use of the epigraphic evidence, esp. on aretalogies and hymns on stone (p. 41-52), on confession inscriptions (p. 65f., 198-204), the perception of a deity (esp. Isis) as saviour (p. 45-47), the use of the word tyrannos as an attribute of gods (p. 62-64), the perception of deities as rulers (esp. of villages in Asia Minor, p. 64-67), the introduction of new gods in Athens (Adonis, Kybele, Bendis, Kotys, Sabazios, Isodaites, p. 102-119) and Delos (Sarapis, the Phoenician Herakles in Delos (p. 120f), the crime of asebeia (p. 123-131), epiphanies of gods (p. 191), and the expression megas theos (p. 194f.).

235) M. VICKERS, The Metrology of Gold and Silver Plate in Classical Greece, in Economics of Cult, p. 53-72: A detailed study of many temple inventories leads to the surprising conclusion that the gold and silver plates dedicated in Greek sanctuaries followed the Achaemenid weight standard (even after Alexander's conquests).

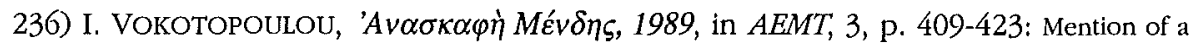
kylix dedicated to Poseidon (p. 416, fig. 17, 5th cent. BC) found in Poseidi; the modern name of the site derives from the name of the god. This is the third sanctuary located on the peninsula of Pallene, after the sanctuaries of Dionysos and Ammon Zeus at Aphyti and that of Artemis at Sane.

237) E. VOUTIRAS, Berufs- und Kultverein: Ein Doumos in Thessalonike, in ZPE, 90

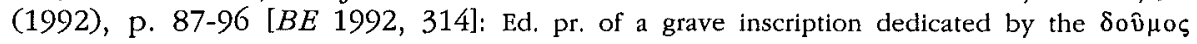

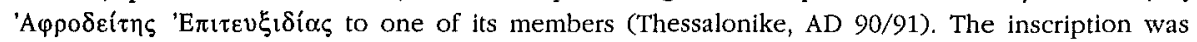

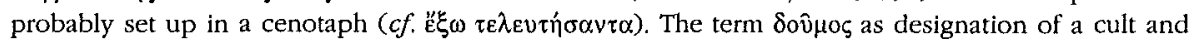
professional association is well attested in Asia Minor, but only here attested in mainland Greece [for a further attestation see supra $\mathrm{n}^{\circ}$ 124]. The officials of this doumos included an archisynagogos, a grammateus, and an exetastes; the latter office is rarely attested for associations. As may be inferred from the representation of the deceased as a captain, this particular association was probably an association of merchants and sailors. The protector of this association was Aphrodite, whose epiklesis is related to the words $\dot{\varepsilon} \pi \imath \tau \gamma \chi \alpha \alpha^{\prime} \omega / \dot{\varepsilon} \pi i \tau \varepsilon v \xi_{1 \zeta}$ ('succeed in your enterprise'). Aphrodite's rôle as protector of sailors and merchants is well attested.

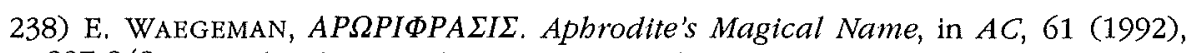

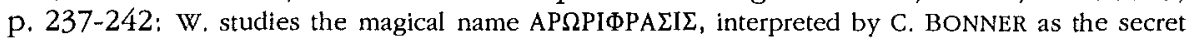
name of Aphrodite. This name appears mostly on amulets with representations of the goddess, in the iconographical typus of Aphrodite binding her hair. Both the representation and the material used for the amulets (usually lapis lazuli) correspond to the descriptions of gems in the Kyranides I, 5, 27f. These amulets were used in love and forensic magic. The colour of the stone may have alluded to the celestial character of the goddess. The two components of her magical name ( $\alpha \rho \omega p t$, $\varphi \rho \alpha \sigma \imath)$ may have been associated with the Greek words $\sigma \alpha \dot{\pi} \pi \varphi \varepsilon \imath \rho \varsigma(c f . \varphi \rho \alpha \sigma i) \sigma \alpha \varphi \imath \rho$, i.e., lapis lazuli) and $\alpha$ pó $\omega$ ('plough', $c f . \alpha \rho \omega \rho 1)$ or $\alpha \rho o v \rho \alpha$, a poetical name for the fertile woman.

239) R. WAGMAN, An Inscribed Architectural Block from Epidauros (IG, IV , I, 129131), in Epigrapbica, 54 (1992), p. 280-283 [BE 1994, 92]: The inscription $I G I^{2} 1,129-131$ (Asklepieion, Epidauros, 3rd cent. AD) contains hymns to all the gods, Pan, and Meter Theon. This stone, an architectural block used for the construction of a monument or building in the late 4th cent. $\mathrm{BC}$, was inscribed many centuries later. The blocks with hymns to Hygieia, Asklepios, Pallas, and Apollon (IG IV $\left.\mathrm{IV}^{2} 1,132-135 \mathrm{II}\right)$ belong to the same construction [on these hymns $c f . E B G R$ 1989, 12].

240) R. WAGMAN, Two Inscribed Sculptural Representations of Pan from Epidauros, in $Z P E, 93$ (1992), p. 45-46 [BE 1993, 94]: W. studies the sculptural features of an inscribed statuette of Pan (IGIV 1,466 , imp.) and a votive relief depicting Pan $\left(I G I V^{2} 1,305\right.$, 4th cent. BC), both dedicated to Asklepios in Epidauros.

241) R. WAGMAN, On $I G I V^{2} 1,132-134$, in $P P, 47$ (1992), p. 469-471: According to M. MITSOS the inscription $I G \mathrm{IV}^{2} 1,132-134$ in Epidauros contained four humns, i.e., the paian of Ariphron to Hygieia and the hymn to Asklepios (col. I), and the hymns to Pater Theon and Palas (col. II, $c f$. SEG 36, 350). W. observes that these texts were written on an architectural structure $[c f$. 
supra $\left.\mathrm{n}^{\circ} 239\right]$; it follows that in the hymn to Pater Theon the missing part is much longer than M. had assumed. [ES]

242) P. WEISs, Einige beschriftete Kleinobjekte, in ZPE, 91 (1992), p. 192-200 [BE 1993, 103]: Ed. pr. of several inscribed objects. An inscribed silver sheet records the dedication of an eagle to Theos Patroios Epekoos, i.e., Zeus (Asia Minor, imp.). A bronze tabula ansata records the dedication of the boxer Moas, also known as Bakchis, to Apollon, in fulfillment of a vow after his victory at the agon Karia (Asia Minor, 1st cent. BC?). W. also restores the inscriptions on two small

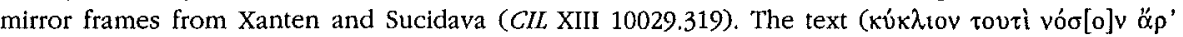

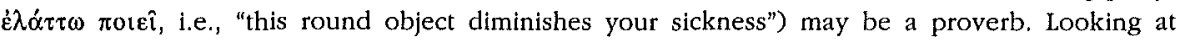
him/herself in the mirror the person saw a smaller image and hoped that the pain (probably lovesickness) would decrease accordingly.

243) J. Winand, Les biérothytes. Recherche institutionnelle (Académie Royale de Belgique, Mémoires de la Classe des Lettres, 2e série, t. LXVIII, Fasc. 4 - 1990), Bruxelles, 1990 [SEG 40, 1717]: Detailed discussion of the offices of hierothytes and archierothytes, attested basically on Rhodes (95 attestations) and in another 19 cities (29 attestations) from the 5th cent. BC to the 3rd cent. AD. The largest part of the study is dedicated to Lindos (p. 32-92), where the majority of the texts were found ( 82 texts). The rest of the evidence comes from Kamiros, Ialysos, Rhodes, the cities of the Rhodian Peraia, the Rhodian colonies, Sparta, Kyrene, Andania, Messene, Tegea, Phigaleia, Megalopolis, Thyrrheion, Histiaia, Demetrias, and Selge [This office is attestated also in Argos (EBGR 1991, 134 and supra $\left.n^{\circ} 119\right)$, Crete (EBGR 1988, 15), and Segesta (supra $n^{\circ} 61$ )]. This office was usually occupied by members of the upper class at the beginning of adulthood, as one of the first offices of their public carreer. The hierothytai usually formed boards, attested in Lindos, Rhodos, Sparta, Kyrene, Phigaliea, Megalopolis, Messene, Andania, and Demetrias; the existence of a board in Selge can be inferred from the office of an archierothytes in this city. Their official seat (hierothyteion) is attested in Lindos. In Lindos the hierothytai were subordinate to the priest of Athena Lindia, assisting in the offering of sacrifices. The hierothytai usually served in the cult of minor deities and heroes. In cities where only one hierothytes existed, his rôle was more important and he served in the major cult of the city. The office of archierothytes, attested for the first time in $296 \mathrm{BC}$, became increasingly important. It was usually occupied after the office of the hierothytes. The office of hierothytes, probably a peculiar Dorian institution, is older than its first epigraphic attestation in the 5th cent. Since it existed in the Rhodian colonies, it must have existed in Rhodos already before the period of colonization.

244) M. WÖRRLE, Neue Inschriften aus Aizanoi I, in Chiron, 22 (1992), p. 337-376 [BE 1993, 547, 551; 1994, 314; SEG 40, 1197]: 1) Ed. pr. of an inscription recording the dedication

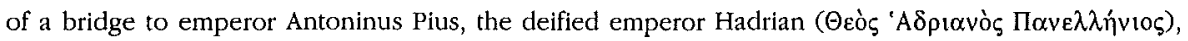
the Eleusinian Goddesses, Athena Polias, Poseidon, and Amphitrite by the benefactor M. Ulpius Appuleius Eurykles (Aizanoi). The text is dated with reference to the 234th Olympic Games and the 6th Panhellenic Agon (AD 157). This synchronism, correlated with the other evidence for the establishment of the Panhellenion and the festival Panhellenia, shows that the first Panhellenia were celebrated in Metageitnion AD 137. Eurykles applied this dating, probably because he wanted to commemorate his journey to Athens and his participation in the session of the Panhellenion (AD 153-157). The deities mentioned in his dedication have no particular relation to Aizanoi; they probably served the same purpose, alluding to Eurykles' travel to Athens (Hadrian Panhellenios, Eleusinian deities, Athena Polias) and his safe return (Poseidon, Amphitrite), 2) Ed. pr. of a dossier of inscriptions in the stadium of Aizanoi commemorating the offices held by Eurykles, his ancestors, and other members of his family. His grandfather Appuleius Flavianus was high priest of the provincial emperor cult in Pergamon (4d) and priest of Dionysos (4b); his embassy to Rome (3) may have been related to a conflict about the sacred land of Zeus [cf. EBGR 1988, 97]. Eurykles' father Appuleianus Flavianus held the offices of agonothetes of Deia, priest of Zeus, priest of Zeus for lifetime, and agonothetes of the great pentaeteric agons (3, 4a; cf. SEG 35, 1365). Eurykles himself served as high priest of the provincial emperor cult in Pergamon (4d) and probably in Smyrna (3), agonothetes of the Deia (3), agonothetes of the provincial agon at Sardis (3), and 
agonothetes of the provincial agon Augusteia Asias (new name of Rhomaia Sebasta) in Pergamon (2b). His wife Severina served together with him as high priestess of Asia (2b); his sister Iulia held the same office in Pergamon together with her husband Asklepiades. Another member of the family served as agonothetes of the agon Traianeia in Pergamon (2a). The grandfather of Eurykles' wife, Antonius Asklepiades, had won the wrestling contest of the boys in the Olympic games of AD 93 (2c, 4e). In an appendix W. restores the honorific inscriptions for Aelia Ammia, high priestess of Asia, found in Amorion and Ephesos [ $c f . E B G R$ 1988, 66; 1990, 160]. According to W.'s convincing restoration of the Ephesian text (I.Ephesos 689) Ammia held the office together with her son

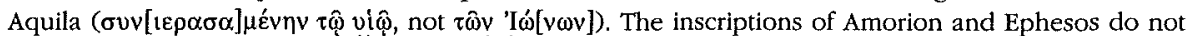
support R.A. KEARSLEY's view that the title asiarches denotes a different function from that of archiereus [EBGR 1990,166; cf. supra $\mathrm{n}^{\circ \mathrm{s}} 96,148$; on the contrary, they confirm the communis opinio, that the high priest of Asia bore the title Asiarches as president of the provincial council.

245) L. ZHMUD, Orpbism and Graffiti from Olbia, in Hermes, 120 (1992), p. 159-168 [BE 1993, 26]: Study of the Orphic graffiti on bone plaques found in Olbia [cf. $E B G R$ 1991, 264].

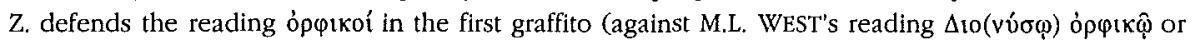

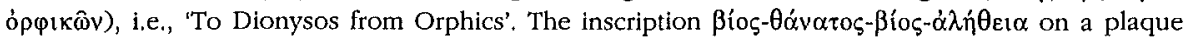
reflects the belief in metempsychosis, temporary death being followed by new birth ( $c f$. the opposition $\psi v \chi \dot{\eta}-\sigma \hat{\omega} \mu \alpha$ on another plaque). Thus, the Olbian graffiti attest the existence of an association, whose members called themselves Orphics, already in the 5th century BC; they also confirm the relation between Dionysiac cult and Orphism. Z. argues that the Orphic movement was not a conglomerate of loosely related phenomena, but had a coherent set of views, allowing, however, for differences between various groups of followers.

Department of Classics

Angelos CHANIOTIS New York University

25 Waverly Place NEW YORK, N.Y. 10003

e-mail: chaniots@is2.nyu.edu 